\title{
Stream-Sediment Geochemistry in Mining-Impacted Streams: Sediment Mobilized by Floods in the Coeur d'Alene-Spokane River System, Idaho and Washington
}

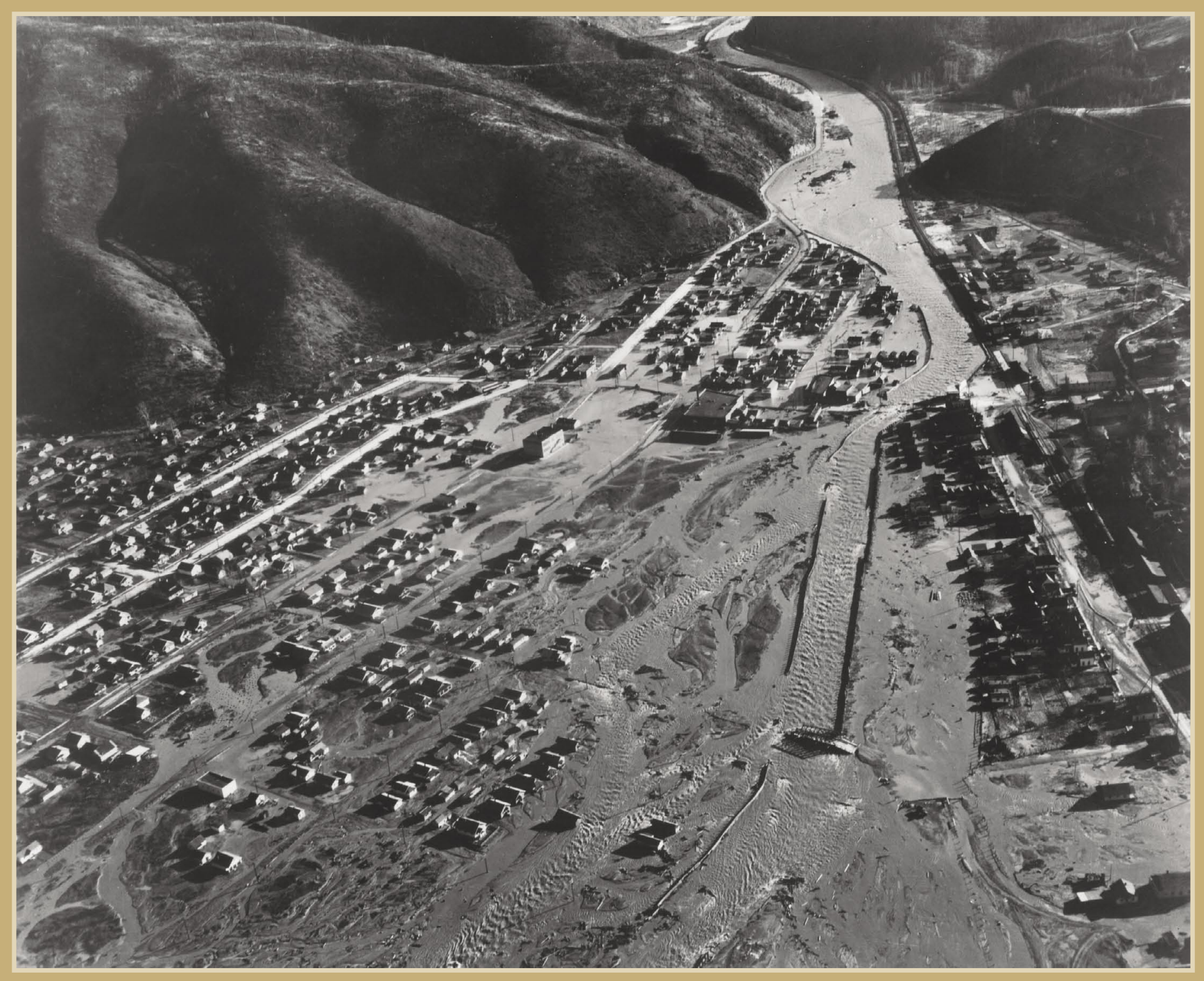

Scientific Investigations Report 2005-5011 
Cover. South Fork of the Coeur d'Alene River at Kellogg, Idaho, near peak streamflow at approximately 10 a.m. P.s.t. on December 23, 1933. Major damage occurred to towns, transportation infrastructure, and ore-concentration-mill facilities in the Coeur d'Alene Mining District from this flood event, estimated to be the third largest since mining began in 1885. Data on sediment mobilized by the second-largest historical flood (in February 1996) and other 1990s flood events are discussed in this report. The largest historical flood in the Coeur d'Alene River basin occurred in January 1974. Photograph by the Washington National Guard; view eastward (upriver). 


\section{Stream-Sediment Geochemistry in Mining- Impacted Streams: Sediment Mobilized by Floods in the Coeur d'Alene-Spokane River System, Idaho and Washington}

By Stephen E. Box, Arthur A. Bookstrom, and Mohammed Ikramuddin

Scientific Investigations Report 2005-5011 


\section{U.S. Department of the Interior \\ Gale A. Norton, Secretary}

\section{U.S. Geological Survey \\ Charles G. Groat, Director}

U.S. Geological Survey, Reston, Virginia: 2005

For sale by U.S. Geological Survey Information Services

Box 25286, Denver Federal Center

Denver, CO 80225

This report and any updates to it are available online at: http://pubs.usgs.gov/sir/2005/5011/

For additional information write to:

U.S. Geological Survey

Box 25046, Mail Stop 421, Denver Federal Center

Denver, C0 80225-0046

Additional USGS publications can be found at:

http://geology.usgs.gov/products.html

For more information about the USGS and its products:

Telephone: 1-888-ASK-USGS (1-888-275-8747)

World Wide Web: http://www.usgs.gov/

Any use of trade, product, or firm names in this publication is for descriptive purposes only and does not imply endorsement of the U.S. Government.

Cataloging-in-publication data are on file with the Library of Congress (URL http://www.loc.gov/).

Produced in the Western Region, Menlo Park, California

Manuscript approved for publication, January 20, 2005

Text edited by George Havach

Layout and design by Sara Boore and Susan Mayfield 


\section{Contents}

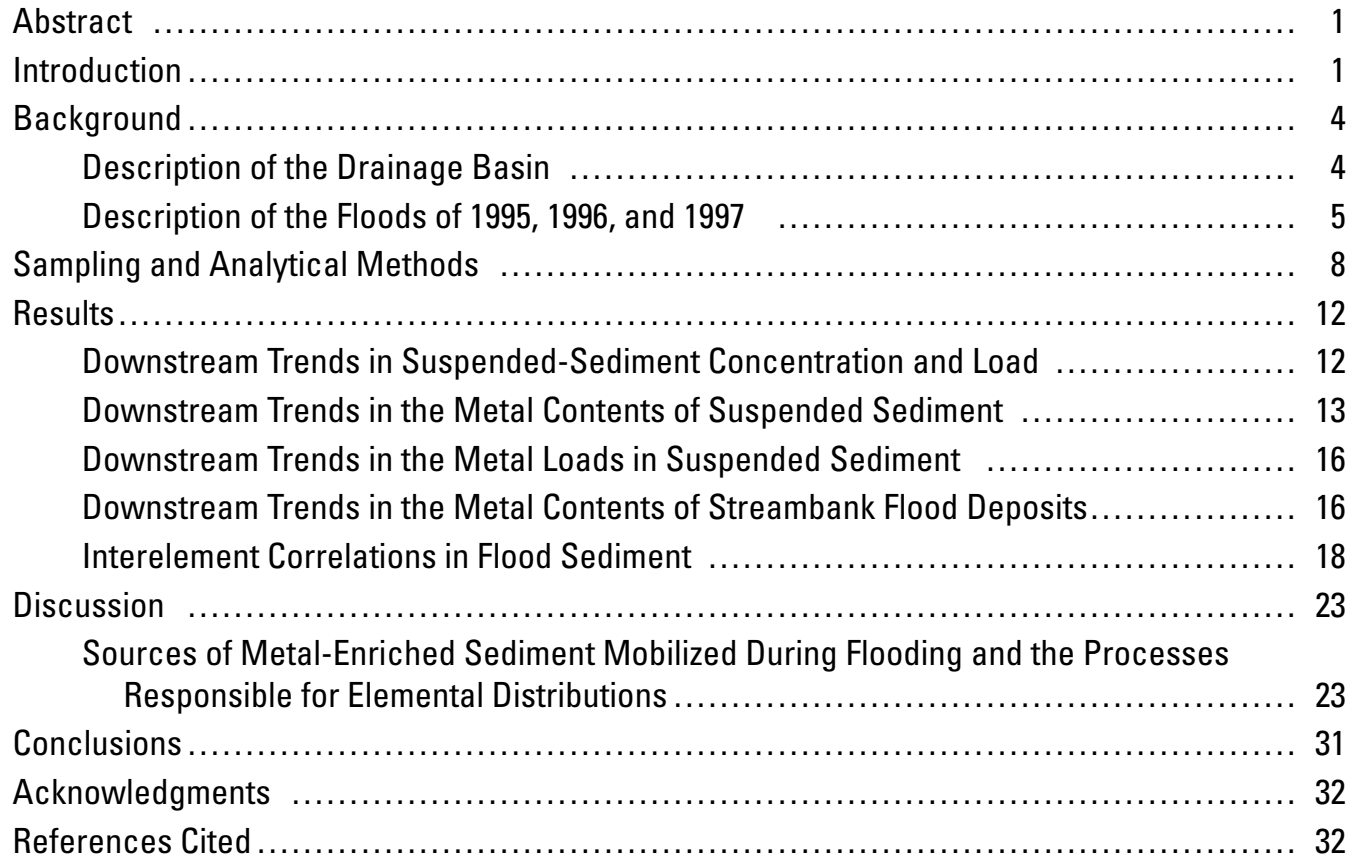

\section{Figures}

1-3. Maps of:

1. Eastern part of the Coeur d'Alene-Spokane River system in northern Idaho, showing locations of sampling sites for suspended sediment during peak streamflows in 1996 and 1997

2. Western part of the Coeur d'Alene-Spokane River system in northern Idaho and eastern Washington, showing locations of sampling sites for suspended sediment during peak streamflows in 1997

3. Eastern part of the Coeur d'Alene-Spokane River system in northern Idaho, showing locations of sampling sites for sediment deposited on streambanks and in marshes during peak streamflows in 1995 and 1996

4. Schematic diagram showing longitudinal stream gradient of the Coeur d'AleneSpokane River system from upstream, east of Wallace, Idaho, to downstream, west of Spokane, Wash.

5-9. Hydrographs of mean daily streamflow at U.S. Geological Survey gaging stations on:

5. The Coeur d'Alene and Spokane Rivers during water years 1995, 1996, and 1997... 7

6. The Coeur d'Alene River at Cataldo, Idaho, during high-flow event of February 20, 1995, with river-surface elevation at U.S. Geological Survey gaging station shown for comparison

7. The Coeur d'Alene River for 30-day period surrounding high-flow event of February 9, 1996, with mean daily river-surface elevations at U.S. Geological Survey gaging station shown for comparison

8. The South Fork of the Coeur d'Alene River at Elizabeth Park, Idaho, for 24-day period centered on high-flow event of January 1, 1997 
9. The Coeur d'Alene and Spokane Rivers for 120-day period in spring 1997, with mean daily river-surface elevations at U.S. Geological Survey gaging station shown for comparison

10. Logarithmic plots of suspended-sediment concentrations in grab samples collected from the Coeur d'Alene and Spokane Rivers and their tributaries, and daily suspended-sediment loads at sampling sites for which mean daily streamflow could be extrapolated from nearby U.S. Geological Survey gaging stations, versus downstream distance from Mullan, Idaho, during high flow events in 1996 and 1997 ... 14

11. Plots of $\mathrm{Pb}, \mathrm{Zn}, \mathrm{Fe}$, and $\mathrm{Mn}$ contents in samples of suspended sediment collected from the Coeur d'Alene and Spokane Rivers and their tributaries and in samples of sediment deposited in flood-plain marshes versus downstream distance from Mullan, Idaho, during high-flow events in 1996 and 1997

12. Logarithmic plots of calculated daily loads of $\mathrm{Pb}$ and $\mathrm{Zn}$ in suspended sediment at selected sampling sites versus downstream distance from Mullan, Idaho, during high-flow events in 1996 and 1997

13. Plots of $\mathrm{Pb}, \mathrm{Zn}, \mathrm{Fe}$, and $\mathrm{Mn}$ contents in samples of streambank sediment deposited along the South Fork and main stem of the Coeur d'Alene River versus downstream distance from Mullan, Idaho, during February 1995 and February 1996 high-flow events

14. Schematic cross section of river channel and natural levee during overbank flooding

15-20. Plots of:

15. Mn versus Fe contents and $\mathrm{Zn}$ versus $\mathrm{Pb}$ contents in flood-sediment samples grouped by sample media, river reach, and flood year

16. $\mathrm{Pb}$ versus $\mathrm{Fe}$ contents and $\mathrm{Pb}$ versus $\mathrm{Mn}$ contents in flood-sediment samples grouped by sample media, river reach, and flood year

17. $Z n$ versus $F e$ contents and $Z n$ versus $M n$ contents in flood-sediment samples grouped by sample media, river reach, and flood year

18. Cd versus $\mathrm{Zn}$ contents, $\mathrm{Ag}$ versus $\mathrm{Pb}$ contents, $\mathrm{Sb}$ versus $\mathrm{Pb}$ contents, $\mathrm{Ag}$ versus $\mathrm{Sb}$ contents, As versus Fe contents, and Cu versus Fe contents in floodsediment samples grouped by sample media, river reach, and flood year ...... 24

19. $\mathrm{Zn}$ versus $\mathrm{Pb}$ contents in potential flood-sediment source materials in and along the South Fork of the Coeur d'Alene River, northern Idaho

20. $\mathrm{Zn}$ versus $\mathrm{Pb}$ contents in potential flood-sediment source materials in and along the main stem of the Coeur d'Alene River downstream from Cataldo, Idaho

21. Schematic cross sections of the lower Coeur d'Alene River valley, northern Idaho, during overbank flooding in February 1996 and May 1997.

\section{Tables}

1. Analytical data for samples of suspended sediment collected from the Coeur d'AleneSpokane River system, northern Idaho and eastern Washington, during high-water events in 1996 and 1

2. Analytical data for samples of overbank sediment from the South Fork and main stem of the Coeur d'Alene River, northern Idaho, deposited during high-water events in 1995 and 1996

3. Daily metal loads in suspended sediment at selected sampling sites in the Coeur d'AleneSpokane River system, northern Idaho and eastern Washington.... 


\title{
Stream-Sediment Geochemistry in Mining-Impacted Streams: Sediment Mobilized by Floods in the Coeur d'Alene-Spokane River System, Idaho and Washington
}

\author{
By Stephen E. Box, Arthur A. Bookstrom, and Mohammed Ikramuddin'
}

\section{Abstract}

Environmental problems associated with the dispersion of metal-enriched sediment into the Coeur d'Alene-Spokane River system downstream from the Coeur d'Alene Mining District in northern Idaho have been a cause of litigation since 1903, 18 years after the initiation of mining for lead, zinc, and silver. Although direct dumping of waste materials into the river by active mining operations stopped in 1968, metalenriched sediment continues to be mobilized during times of high runoff and deposited on valley flood plains and in Coeur d'Alene Lake (Horowitz and others, 1993). To gauge the geographic and temporal variations in the metal contents of flood sediment and to provide constraints on the sources and processes responsible for those variations, we collected samples of suspended sediment and overbank deposits during and after four high-flow events in 1995, 1996, and 1997 in the Coeur d'Alene-Spokane River system with estimated recurrence intervals ranging from 2 to 100 years. Suspended sediment enriched in lead, zinc, silver, antimony, arsenic, cadmium, and copper was detected over a distance of more than $130 \mathrm{mi}$ (the downstream extent of sampling) downstream of the mining district. Strong correlations of all these elements in suspended sediment with each other and with iron and manganese are apparent when samples are grouped by reach (tributaries to the South Fork of the Coeur d'Alene River, the South Fork of the Coeur d'Alene River, the main stem of the Coeur d'Alene River, and the Spokane River). Elemental correlations with iron and manganese, along with observations by scanning electron microscopy, indicate that most of the trace metals are associated with $\mathrm{Fe}$ and $\mathrm{Mn}$ oxyhydroxide compounds. Changes in elemental correlations by reach suggest that the sources of metal-enriched sediment change along the length of the drainage. Metal contents of suspended sediment generally increase through the mining district along the South Fork of the Coeur d'Alene River, decrease below the confluence of the North and South Forks, and then increase again downstream of the gradient flattening below Cataldo. Metal contents of suspended sediment in the Spokane River below Coeur d'Alene

${ }^{1}$ Eastern Washington University, Cheney,Wash.
Lake were comparable to those of suspended sediment in the main stem of the Coeur d'Alene River above the lake during the 1997 spring runoff, but with somewhat higher Zn contents. Daily suspended-sediment loads were about 100 times larger in the 1996 flood (50-100-year recurrence interval) than in the smaller 1997 floods (2-5-year recurrence intervals). Significant differences in metal ratios and contents are also apparent between the two flood types. The predominant source of suspended sediment in the larger 1996 flood was previously deposited, metal-enriched flood-plain sediment, identified by its $\mathrm{Zn} / \mathrm{Pb}$ ratio less than 1 . Suspended sediment in the smaller 1997 floods had metal ratios distinct from those of the floodplain deposits and was primarily derived from metal-enriched sediment stored within the stream channel, identified by a $\mathrm{Zn} / \mathrm{Pb}$ ratio greater than 1 . Sediment deposited during overbank flooding on the immediate streambank or natural levee of the river typically consists of sandy material with metal ratios and contents similar to those of the sandy streambed sediment in the adjacent river reach. Samples of overbank deposits in backlevee marshes collected after the 1996 flood have metal ratios similar to those of peak-flow suspended sediment in the same river reach, but generally lower metal contents.

\section{Introduction}

The South Fork of the Coeur d'Alene River in northern Idaho (fig. 1) drains the Coeur d'Alene Mining District, one of the world's largest producers of silver and one of the Nation's largest producers of lead and zinc (Long, 1998). More than 130 million tons of $\mathrm{Pb}-\mathrm{Zn}$-Ag sulfide ores has been mined from more than 20 major mines in the district since 1885 (Long and others, 1998). From the onset of ore production in the 1880 s to 1968 , most of the ore-concentration mills in the district piped or flumed pulverized waste material ("tailings") from the concentration process directly into the river, resulting in gray opaque river water charged with suspended sediment year round (Ellis, 1940). This sediment overloading of the river, along with the flat-bottomed topography of the Coeur d'Alene River valley and its history of repeated inundation, resulted in incorporation of this metal-enriched material into 
stream sediment and flood-plain soils over nearly the entire length and breadth of the valley floor from the mining district downstream into Coeur d'Alene Lake, a distance of about 60 mi (Bookstrom and others, 2001). Direct dumping of tailings into the river stopped in 1968, when tailings-settling ponds became legally required for all active mining operations (Long, 1998). Since that time, the river water has substantially cleared, and suspended-sediment concentrations are elevated only during times of high runoff. Despite this remedial action, however, sedimentation rates and metal contents of new sediment deposited in Coeur d'Alene Lake have not decreased since 1968 (Horowitz and others, 1995), as previously deposited metal-enriched sediment in the valley continues to be remobilized by both physical and chemical processes.

Sediment carried during high-flow events typically is physically remobilized from unconsolidated materials within
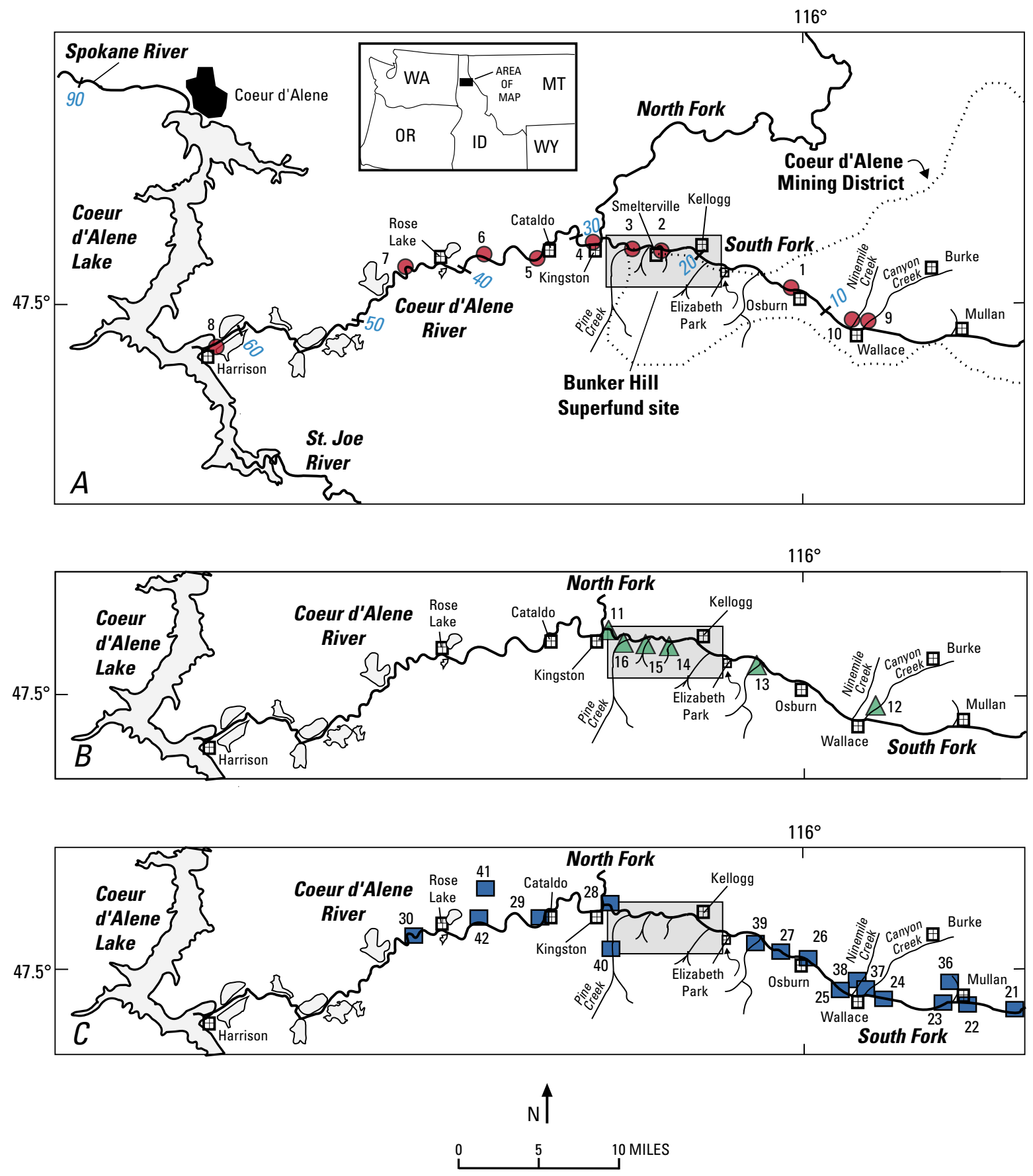

Figure 1. Eastern part of the Coeur d'Alene-Spokane River system in northern Idaho, showing locations of sampling sites for suspended sediment during peak streamflow of February 9-10, 1996 ( $A$; red circles), January 2, 1997 ( $B$; green triangles), and May 19-20, 1997 ( $C$; dark-blue squares). Blue italic numbers, river miles below Mullan. See table 1 for analytical data. 
the drainage basin, although precipitation of solids and (or) ionic sorption onto solids from the dissolved state can also occur, owing to changing chemical conditions in the stream. Flood-sediment sources consist of erodible materials exposed in streambeds, streambanks, and flood plains of the Coeur d'Alene-Spokane River system (figs. 1,2). Although these source materials may undergo geochemical changes (weathering) under various surface conditions during the year, incorporation of the source materials into the suspended-sedi- ment load is generally dominated by physical processes. The elemental composition of a particular flood-sediment sample is controlled by the mixture of source materials accessed by floodwaters upstream from the sampling site, the degree to which the shear stress of the flowing waters can overcome the inertia of source particles, and the subsequent sorting (based on particle size and density) of the mobilized material by the floodwaters. These factors can change during a high-flow event, and so suspended-sediment concentrations and their
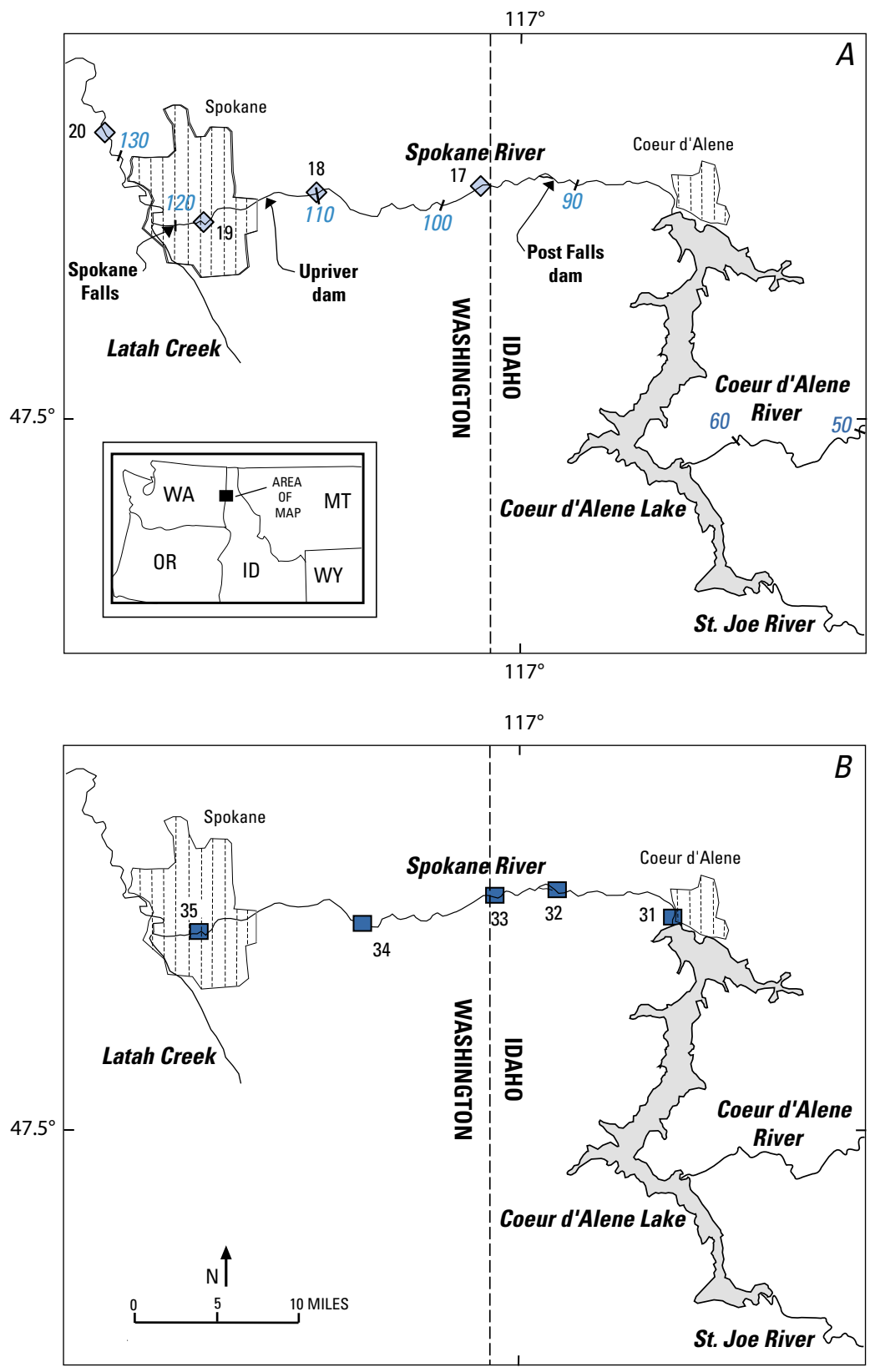

Figure 2. Western part of the Coeur d'Alene-Spokane River system in northern Idaho and eastern Washington, showing locations of sampling sites for suspended sediment during peak streamflow of May 2, 1997 ( $A$; pale-blue diamonds), and May 19-20, 1997 ( $B$; dark-blue squares). Map area overlaps western part of map area in figure 1. Blue italic numbers, river miles below Mullan, Idaho. See table 1 for analytical data. 
elemental composition can change accordingly over the duration of the event (Horowitz and others, 1990).

We collected samples of sediment mobilized in the Coeur d'Alene-Spokane River system (figs. 1-3) during and after four high-flow episodes in 1995, 1996, and 1997 to characterize its elemental composition and downstream variation during an individual high-flow event, and its variation between different high-flow events. Three sample media were used for this study: (1) fine suspended sediment, collected during peak flow; (2) sandy sediment deposited on the immediate streambank or natural levee of the river during overbank flooding; and (3) fine sediment deposited in backlevee marshes at a greater distance from the river channel during overbank flooding. These three sample media represent flood-mobilized sediment that was sampled on different time scales (instantaneous versus cumulative high-flow event) and with different sorting histories (washload sediment in true suspension, levee sediment deposited from traction currents, and marsh sediment deposited from part of the washload).

In this report, we present the results of chemical analyses of flood sediment from the Coeur d'Alene-Spokane River system (figs. 1-3) and discuss how the data constrain our understanding of the sources and processes that control the elemental composition of sediment mobilized during highflow events. We begin by describing the drainage basin in and downstream from the mining district and the several sampled high-flow events. We compare the downstream variations in metal contents and loads for each high-flow event and for each sample media. Finally, we discuss the variations in elemental composition in terms of their relevance to understanding the variations in flood-sediment sources during highstreamflow events.
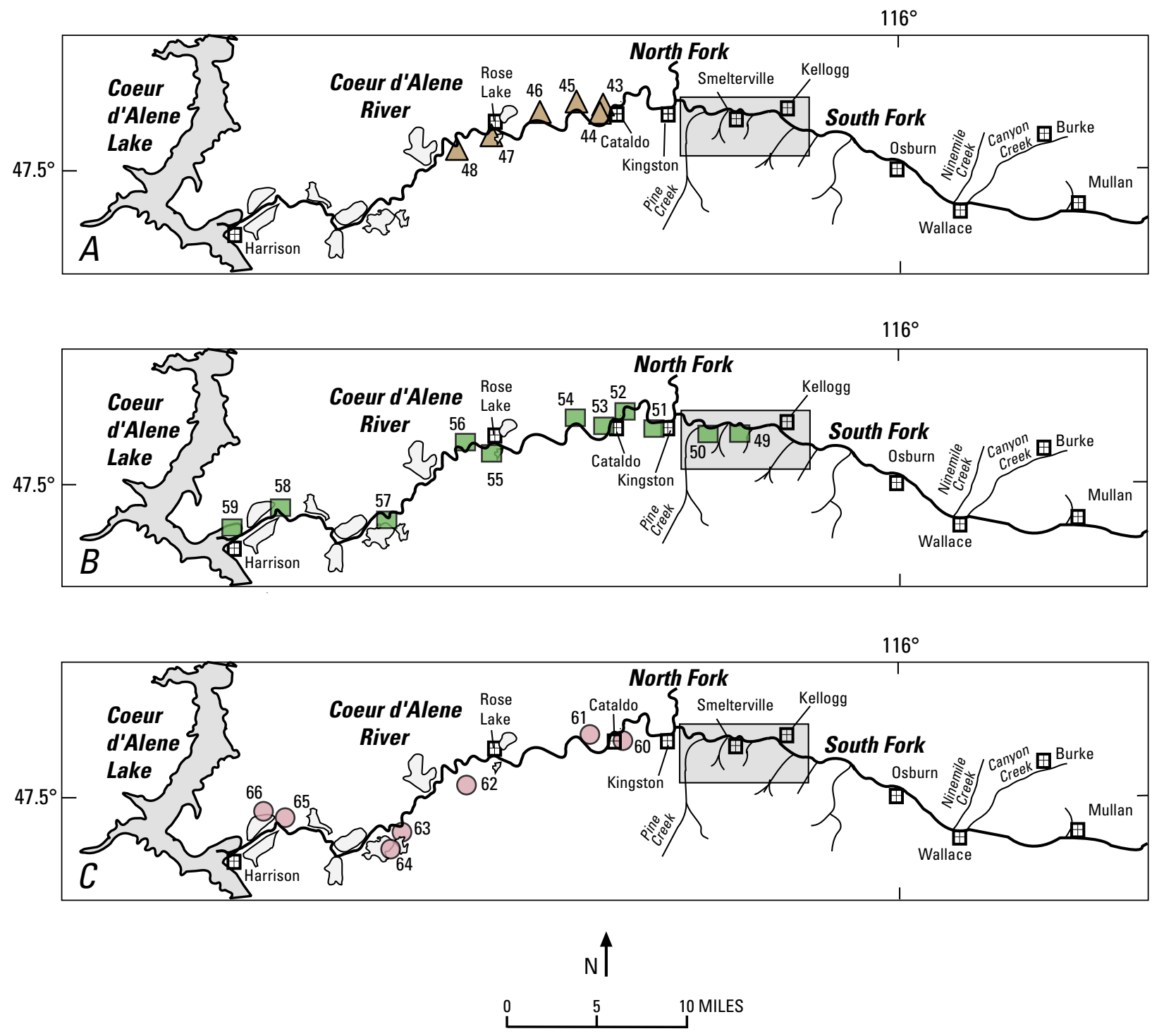

Figure 3. Eastern part of the Coeur d'Alene-Spokane River system in northern Idaho (see fig. 1 for index map), showing locations of sampling sites for sediment deposited on streambanks during peak streamflow of February 21, 1995 ( $A$; tan triangles), and for sediment deposited on streambanks ( $B$; green squares) and sediment deposited in marshes ( $C$; pink circles) during and after peak streamflow of February 9-10, 1996. See table 2 for analytical data. 


\section{Background}

\section{Description of the Drainage Basin}

The drainage basin of the Coeur d'Alene-Spokane River system in northern Idaho and eastern Washington (figs. 1, 2) that is impacted by mining can be divided into four reaches. The first reach comprises the South Fork and main stem of the Coeur d'Alene River between the confluence of the North and South Forks and the gradient flattening downstream from the town of Cataldo, Idaho. In this reach, the river runs in a braided, cobbly channel flanked by a sandy flood-plain surface of varying width (0-1 mi). The channel in several segments of this reach has been significantly modified with artificial riprap banks and levees and is spanned by numerous bridges. The second reach comprises the lower Coeur d'Alene River from below Cataldo to the delta into Coeur d'Alene Lake at Harrison, Idaho. In this reach, the river runs in a deep, sandbottomed channel through a wide (0.3-2.0 mi) marshy valley flanked by narrow (avg 0.12 mi wide) natural levees. During low-flow periods, the channel in this reach is backflooded by the waters of Coeur d'Alene Lake. The third reach comprises the main body of Coeur d'Alene Lake, a natural lake that drowns a Quaternary river valley. The lake has two main tributaries of approximately equal size: the Coeur d'Alene and St. Joe Rivers. The lake has relatively steep bedrock walls and water depths of as much as $250 \mathrm{ft}$ (Woods and Berenbrock, 1994). The fourth reach comprises the Spokane River, which flows westward out of the north end of Coeur d'Alene Lake to Spokane, Wash. In this reach, the river runs in a cobble- and boulder-filled channel incised into Quaternary glacial-outburst-flood gravel, with almost no natural flood plain (Box and Wallis, 2002). A longitudinal plot of the stream gradient of the Coeur d'Alene-Spokane River system is shown in figure 4.

The responses of these four river reaches to high-flow conditions differ in relation to the valley characteristics. In the first reach, where unconstrained by artificial modifications, the river occupies a broad channel during times of high runoff, with cutbanks of metal-enriched (relative to premining deposits or sediment along unmined tributaries), sandy flood-plain deposits. As a result of flood-plain aggradation during the first decades of mining activity, very little of what is considered to be the alluvial flood plain along the South Fork of the

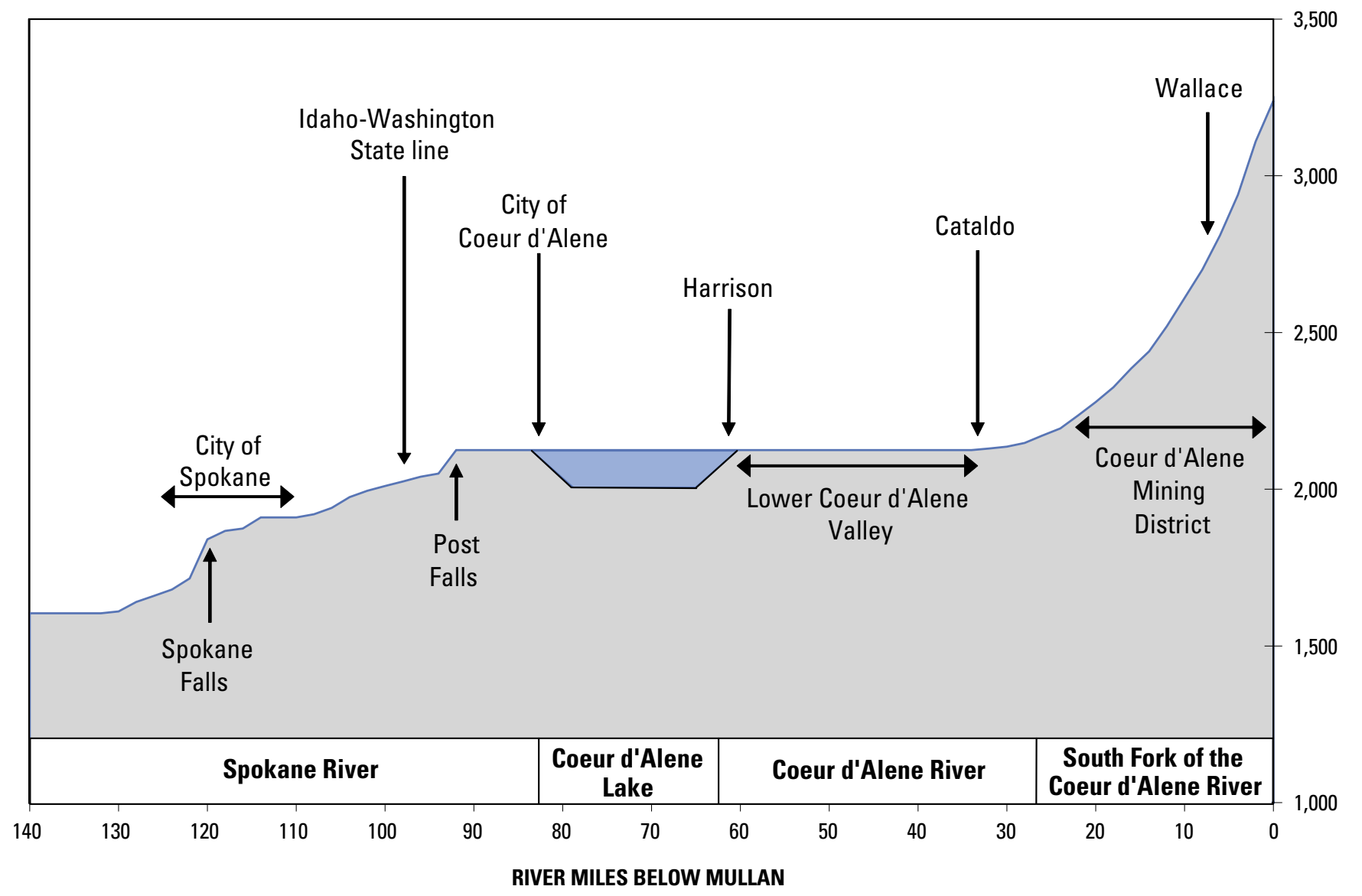

Figure 4. Longitudinal stream gradient of the Coeur d'Alene-Spokane River system from upstream, east of Wallace, Idaho (right) to downstream, west of Spokane, Wash. (left; see figs. 1 and 2 for locations). Steep upstream gradient at Wallace gradually decreases to just below Cataldo, where waters of Coeur d'Alene Lake backflood lower 28 mi of the Coeur d'Alene River channel. Lake waters are impounded by a bedrock constriction on the Spokane River at Post Falls, now augmented by the Post Falls dam. 
Coeur d'Alene River in the mining district was flooded during 1995-97 high-flow events, even though the February 1996

flood was one of the three highest flows recorded on the South Fork since 1920. During low-flow conditions, water occupies only a narrow strip of the high-water channel.

In the second reach, the Coeur d'Alene River fills a narrow, deep channel floored by metal-enriched sand and flanked by narrow natural levees and cutbanks of metal-enriched fine sand and silt. A wide flood plain of backlevee marshes and shallow flood plain lakes is generally connected to the river channel by natural or manmade side channels (Bookstrom and others, 1999). For most of the year, the channel is backflooded by the waters of Coeur d'Alene Lake to a point just below the town of Cataldo, Idaho (fig. 1). Current is perceptible only during high-flow events; flow velocity reached more than 7 $\mathrm{ft} / \mathrm{s}$ during the February 1996 flood (M.A. Beckwith, written commun., 1996). The river-surface elevation in this reach is controlled both by the flow rate on the Coeur d'Alene River upstream at Cataldo and by the surface elevation of Coeur d'Alene Lake downstream. Overbank flooding occurs in most years, and nearly all of the flood plain was inundated during each of the sampling events in this study.

In the third reach, the surface elevation of Coeur d'Alene Lake is controlled from mid-June to mid-November by a gated dam at Post Falls, Idaho (figs. 2, 4). All the sampling events in this study was conducted while the dam gates were wide open, at which times the outflow from the lake is restricted by a narrow bedrock gorge at the damsite at Post Falls, such that the natural outflow rate is directly correlative with the lake-surface elevation. During high-flow events on the main tributaries to the lake (Coeur d'Alene and St. Joe Rivers), inflow exceeds outflow, causing the lake level to rise until outflow equals

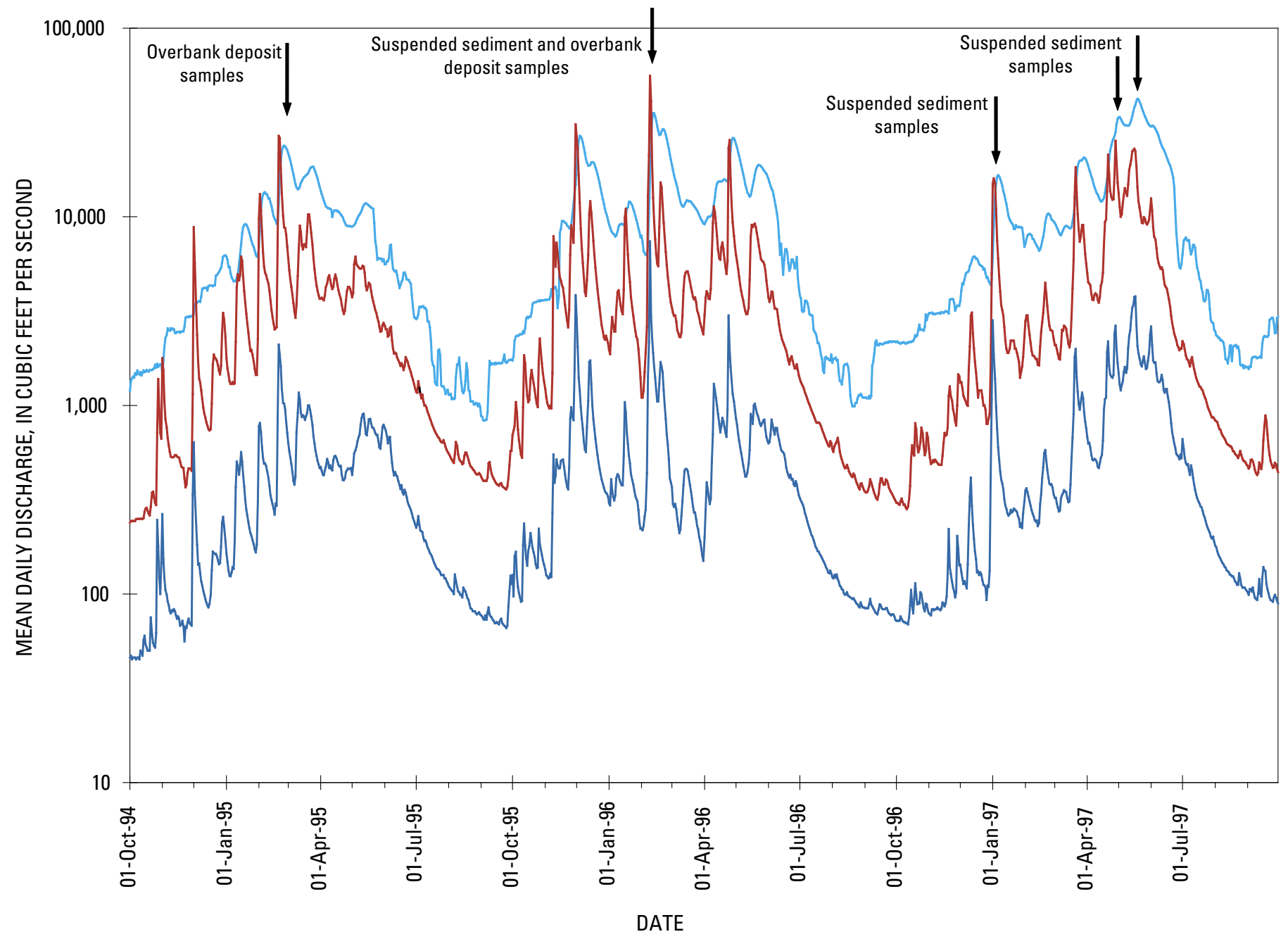

Figure 5. Hydrograph of mean daily streamflow at U.S. Geological Survey gaging stations on the South Fork of the Coeur d'Alene River at Elizabeth Park, Idaho (dark-blue curve), on the Coeur d'Alene River at Cataldo, Idaho (red curve), and on the Spokane River at Spokane, Wash. (light-blue curve) during water years 1995, 1996, and 1997 (see figs. 1 and 2 for locations). Arrows denote points on hydrograph when samples of flood sediment (suspended sediment during high-flow event and overbank deposits after waning of the high-flow event) were collected. 
inflow. As high flow on the tributaries diminishes, outflow exceeds inflow and the lake level falls until outflow and inflow are equal. Average residence times for lake water were calculated for water years 1991 and 1992 at 160 and 325 days, respectively (Woods and Beckwith, 1995). The traveltime of water (and suspended sediment) from the inlet at Harrison, Idaho (fig. 1) to the outlet at Coeur d'Alene, Idaho, during high-flow events (for example, the May 1997 flood) is much shorter than these average residence times during runoff events (on the order of days to weeks), because of faster movement of the shallow lake waters (P.F. Woods, written commun., 2000).

In the fourth reach, the Spokane River flows westward in a shallow channel incised into coarse Quaternary gravel. Most of the channel is occupied even at low water, with almost no natural flood plain. Deposits of sand or finer material are scarce (except behind the Upriver dam) above Spokane Falls
(Box and Wallis, 2002). The Upriver dam backs up a small reservoir in the incised channel for about 1 mile. No surfacewater tributaries join the Spokane River from the outlet of Coeur d'Alene Lake to just west of Spokane Falls, where the river turns northward at the inflow of Latah Creek (figs. 2, 4).

\section{Description of the Floods of 1995, 1996, and 1997}

Several high-flow events occurred in the Coeur d'AleneSpokane River system (figs. 1, 2) during water years 1995, 1996, and 1997 (fig. 5; U.S. Geological Survey, 1996, 1997, 1998). Winter (between mid-November and mid-March) high-flow events typically result from warm Pacific winter storms ("pineapple express") that bring a sudden warming to above-freezing temperatures and, commonly, heavy rains to northern Idaho. Rapid snowmelt produces an abrupt increase in runoff to peak

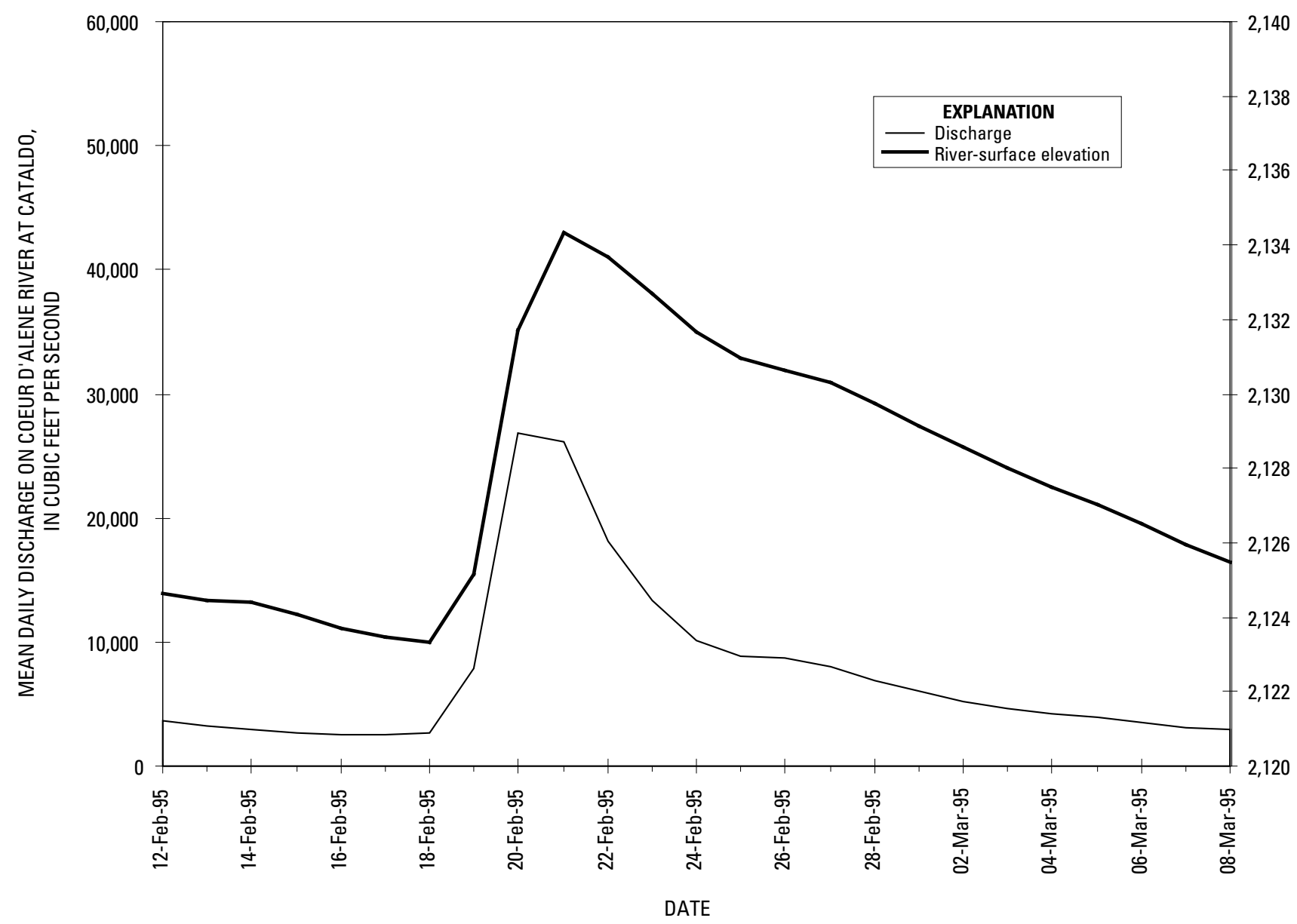

Figure 6. Hydrograph of mean daily streamflow at U.S. Geological Survey gaging station on the Coeur d'Alene River at Cataldo, Idaho (thin line, with scale on left axis), during high-flow event of February 20, 1995, with river-surface elevation at U.S. Geological Survey gaging station on the Coeur d'Alene River at Rose Lake, Idaho (thick line, with scale on right axis) shown for comparison. Rose Lake gaging station is near upstream end of 28-mi-long backflooded reach of the lower Coeur d'Alene River, where river elevation is controlled both by inflow from river at Cataldo and by lake-surface elevation. Overbank deposits from this high-flow event were sampled at six sites (fig. 3A) on February 23, 1995. 

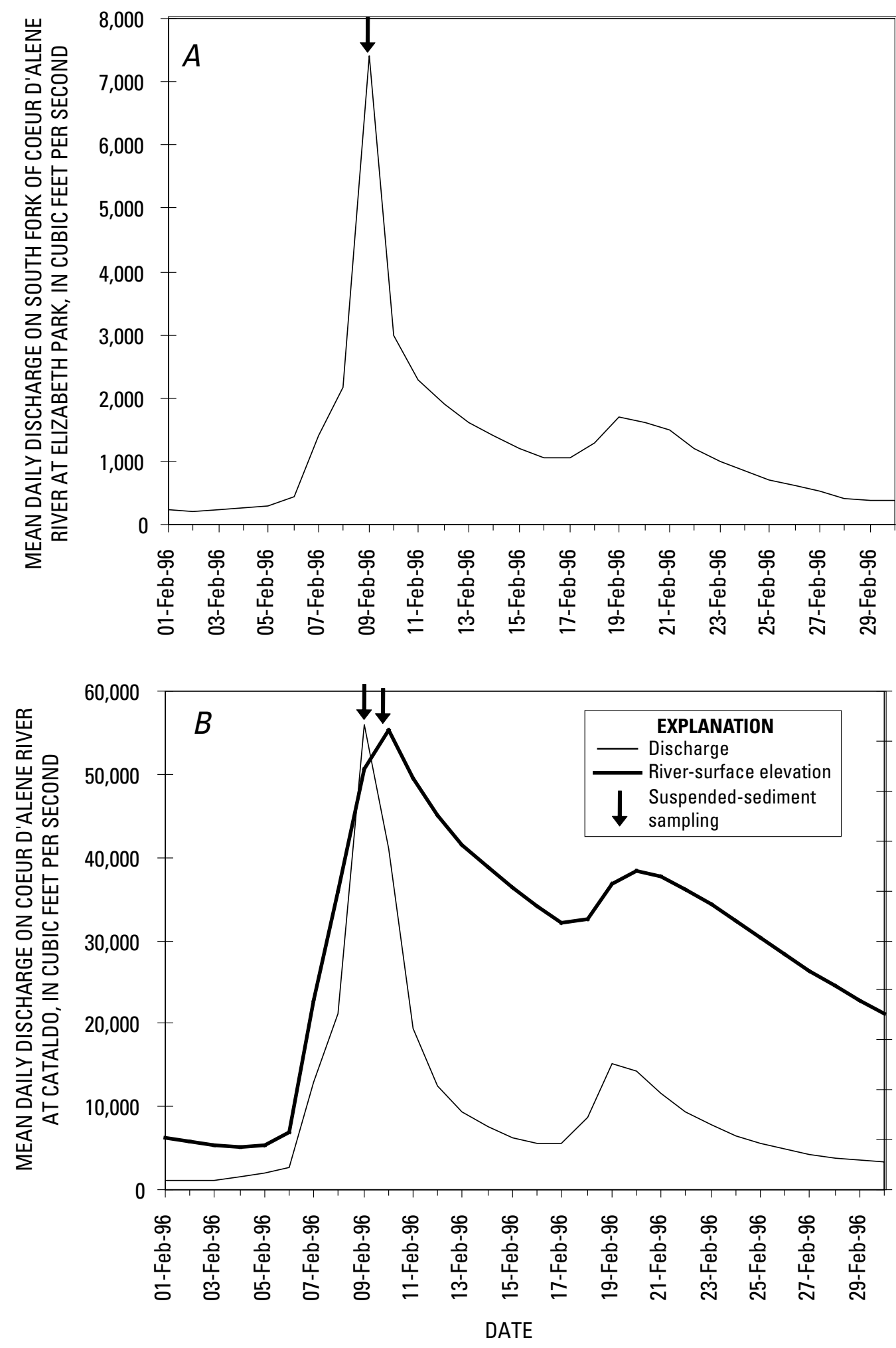

Figure 7. Hydrograph of mean daily streamflow at U.S. Geological Survey gaging stations on the South Fork of the Coeur d'Alene River at Elizabeth Park, Idaho $(A)$, and on main stem of the Coeur d'Alene River at Cataldo, Idaho ( $B$; thin line, scale on left axis), for 30-day period surrounding the high-flow event of February 9, 1996, with mean daily river-surface elevations at U.S. Geological Survey gaging station on the Coeur d'Alene River at Rose Lake, Idaho ( $B$; thick line, scale on right axis) shown for comparison (see fig. 1 for locations). Arrows denote points on hydrograph when suspended-sediment samples were collected. Overbank deposits from this event were sampled at 18 sites (figs. 3B, 3C) after floodwaters receded in March and April 1996. 
flow from winter base-level flows; an equally abrupt cooling to below-freezing temperatures after storm passage returns the runoff to midwinter low-flow levels more gradually. The February 1995, February 1996, and January 1997 high-flow events were all of this abrupt type. Spring runoff (mid-March to mid-June) results from melting of the winter snowpack. The gradual, sustained snowmelt produces a broad runoff high, on which spring rainstorms superimpose sharper runoff peaks. The spring runoff of April through June 1997 was of this more gradual type.

The February 1995 flood (fig. 6) was the highest flow on the Coeur d'Alene River recorded since 1982 and the first peak flow greater than 15,000 $\mathrm{ft}^{3} / \mathrm{s}$ recorded since April 1991. Instantaneous peak flow on February 20 for the main stem of the Coeur d'Alene River at Cataldo, Idaho (fig. 1) was 35,200 $\mathrm{ft}^{3} / \mathrm{s}$, the eighth-highest peak flow recorded since 1920, with a calculated recurrence interval at Cataldo of about 10 years (Kjelstrom, 1996). The water-surface elevation of the lakeinfluenced lower Coeur d'Alene River at the Rose Lake gage below Cataldo rose $11 \mathrm{ft}$ in 3 days (fig. 6), attaining a maximum elevation of $10 \mathrm{ft}$ above summer lake-surface elevation $(2,125 \mathrm{ft}$ above sea level) on February 21 and a maximum current velocity greater than $5 \mathrm{ft} / \mathrm{s}$ (M.A. Beckwith, written commun., 1996). Almost no overbank flooding occurred along the South Fork, and only minor overbank flooding occurred on the main stem of the Coeur d'Alene River above Cataldo. Most of the flood plain below Cataldo was inundated, except for that part south of the river protected by a railroad embankment and the crests of some natural levees in the upper half of the valley below Cataldo. Streambank flood deposits were sampled at six sites on the Coeur d'Alene River below Cataldo through the upper half of the lower Coeur d'Alene Valley on February 23 (fig. 3A).

The February 1996 flood (fig. 7) had the second-highest flow on the Coeur d'Alene River recorded at the U.S. Geological Survey gaging station at Cataldo (fig. 1) since gaging began in 1920, surpassed only by the flood of January 1974 (Beckwith and others, 1996). Using data from the Spokane

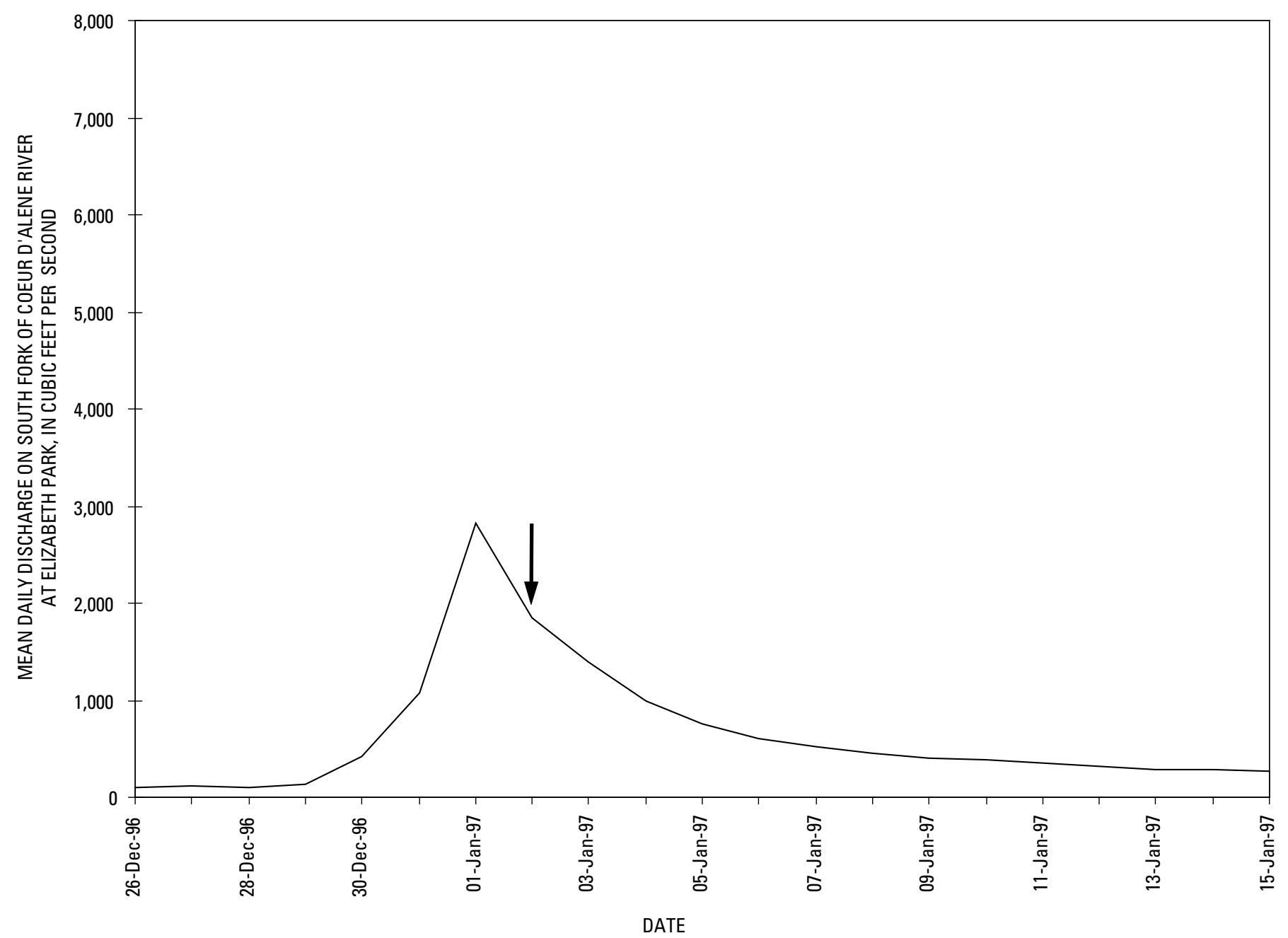

Figure 8. Hydrograph of mean daily streamflow at U.S. Geological Survey gaging station on the South Fork of the Coeur d'Alene River at Elizabeth Park, Idaho (fig. 1), for 24-day period centered on the high-flow event of January 1, 1997. Arrow denotes point on hydrograph when suspended-sediment samples were collected. 


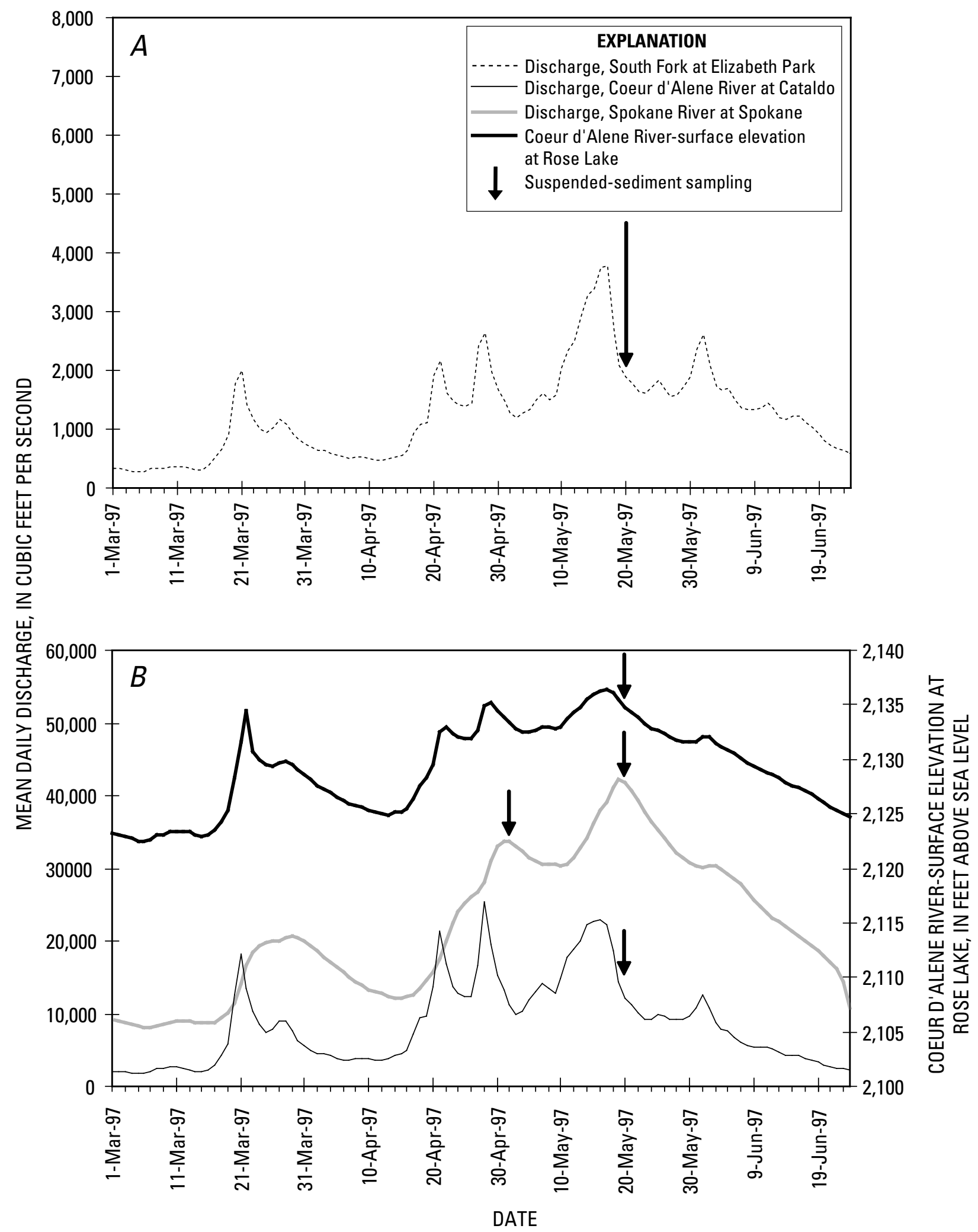

Figure 9. Hydrograph of mean daily streamflow at U.S. Geological Survey gaging stations on the South Fork of the Coeur d'Alene River at Elizabeth Park, Idaho $(A)$, and on main stem of the Coeur d'Alene River at Cataldo, Idaho ( $B$; thin line, with scale on left axis) and on the Spokane River at Spokane, Wash. (B; thick gray line, with scale on left axis), for 120-day period in spring 1997, with mean daily river-surface elevations at U.S. Geological Survey gaging station on the Coeur d'Alene River at Rose Lake, Idaho ( $B$; thick black line, scale on right axis) shown for comparison (see figs. 1 and 2 for locations). Arrows denote points on hydrograph when suspended-sediment samples were collected. 
River gage at Spokane (fig. 2), with a period of record dating back to 1891, the February 1996 flood apparently had the second-highest peak flow on the Coeur d'Alene River since at least 1891, soon after production began in the Coeur d'Alene Mining District. Instantaneous peak flow on February 9 for the South Fork of the Coeur d'Alene River at Elizabeth Park (fig. 1) was $9,600 \mathrm{ft}^{3} / \mathrm{s}$ and for the main stem at Cataldo was 68,300 $\mathrm{ft}^{3} / \mathrm{s}$, with a calculated recurrence interval at Cataldo of about 100 years (Kjelstrom, 1996). The water-surface elevation of the lake-influenced lower Coeur d'Alene River at Rose Lake (fig. 1) rose $17 \mathrm{ft}$ in 4 days (fig. 7B), attaining a maximum elevation of $14 \mathrm{ft}$ above summer lake-surface elevation on February 10 and a maximum current velocity in the channel greater than $7 \mathrm{ft} / \mathrm{s}$ on February 9 (Mike Beckwith, written commun., 1996). Minor overbank flooding occurred along the South Fork, but major overbank flooding occurred on the main stem of the Coeur d'Alene River above Cataldo, causing extensive flood damage in the towns of Cataldo and Kingston. The entire flood plain below Cataldo was inundated, including the railroad embankment, which was washed out in many places. Suspended sediment was sampled at 10 sites on the South Fork and main stem of the Coeur d'Alene River during the 24 hours surrounding the peak flow on February 9 and 10 (fig. 1A). Sediment deposited on streambanks and in marshes during the February flood was sampled at 18 sites along the same channel segment on March 28 and April 12 (figs. 3B, 3C).

The January 1997 high-flow event (fig. 8) was much smaller than the previous two floods. Instantaneous peak flow on January 1 for the South Fork at Elizabeth Park (fig. 1) was 3,840 $\mathrm{ft}^{3} / \mathrm{s}$ and for the main stem of the Coeur d'Alene River at Cataldo was $20,800 \mathrm{ft}^{3} / \mathrm{s}$, with a calculated recurrence interval at Cataldo of about 2 years (Kjelstrom, 1996). Suspended sediment was sampled at five sites on the South Fork and its tributaries after peak flow on January 2 (fig. $1 B$ ), when daily mean streamflow on the South Fork was $1,890 \mathrm{ft}^{3} / \mathrm{s}$ (fig. 8).

The May 1997 flood (fig. 9) occurred as a long-delayed spring runoff from an abnormally heavy winter snowpack. Several flow peaks occurred between March 21 and June 1. Instantaneous peak flow for the South Fork at Elizabeth Park (fig. 1) was $4,230 \mathrm{ft}^{3} / \mathrm{s}$ on May 17; peak flow on the main stem of the Coeur d'Alene River at Cataldo was 23,300 $\mathrm{ft}^{3} / \mathrm{s}$ on May 16, with a recurrence interval at Cataldo of about 3-4 years (Kjelstrom, 1996). The water-surface elevation of the lake-influenced lower Coeur d'Alene River at Rose Lake increased $11 \mathrm{ft}$ in 30 days (fig. 9B), attaining a maximum elevation of $11 \mathrm{ft}$ above summer lake-surface elevation on May 17 and a maximum current velocity in the channel estimated at less than $2 \mathrm{ft} / \mathrm{s}$. The long-duration runoff maintained a high surface elevation of Coeur d'Alene Lake throughout the month of May, resulting in persistent high flow on the Spokane River below the lake outlet. Instantaneous peak flow for the Spokane River at Post Falls (fig. 2) was 43,900 $\mathrm{ft}^{3} / \mathrm{s}$ on May 19 (fig. 9B), the fourth-highest flow on the Spokane River since 1891, with a calculated recurrence interval at Post Falls of 25 years (Kjelstrom, 1996). Total runoff on the Spokane River for May 1997 was the highest monthly volume recorded since gaging began in 1891. Almost no overbank flooding occurred during May 1997 along the South Fork or main stem of the Coeur d'Alene River above Cataldo, or along the Spokane River. In contrast, the entire flood plain in the lower Coeur d'Alene River valley below Cataldo was inundated throughout the month of May, owing to the high surface elevation of Coeur d'Alene Lake. Suspended sediment was sampled at 22 sites on the South Fork and main stem of the Coeur d'Alene River (fig. $1 C$ ) on May 20 (after peak flow), on the Spokane River at 4 sites (fig. $2 A$ ) on May 2 (before peak flow), and on the Spokane River at 5 sites (fig. 2B) on May 19-20 (during peak flow).

\section{Sampling and Analytical Methods}

A total of 42 suspended-sediment samples were collected from the Coeur d'Alene-Spokane River system during peak flows on February 9-10, 1996, January 2, 1997, and May 19-20, 1997. The suspended-sediment samples analyzed in this report represent grab samples of the washload portion of the total sediment load in suspension at the time of sampling. Samples were collected in February 1996 from the river's edge directly into 2-gal plastic Ziploc bags held below the surface of the water. All other samples (except samples 10 and 22, collected as above) were collected with a 1-gal plastic bucket tied to a rope and thrown into the center of the stream from the downstream side of a bridge. Upon retrieval of the bucket, samples were transferred to 1-gal plastic Ziploc bags. Samples were transported to the laboratory and allowed to settle.

Suspended sediment was extracted from the 1996 and 1997 samples by slightly different procedures. The 1996 samples were allowed to settle for 2 weeks. Clear water was poured off the top of the bag until about $0.5 \mathrm{~L}$ remained. The sample was then transferred to a glass jar, and both the glass jar and plastic bag were heated in an oven at $80^{\circ} \mathrm{C}$ for several days. Clean sample containers were labeled and weighed, the dried sediment from both the glass jar and plastic bag was transferred to them, and the containers were reweighed. The 1997 samples were allowed to settle for 3 weeks. Clear water was then poured off the top of the bag until 1 to $2 \mathrm{~L}$ remained. The sample was then transferred to a glass jar and again allowed to settle for 24 hours. Clear water was poured off the top of the jar until about $200 \mathrm{~mL}$ remained, which was spun in a centrifuge on a high setting for 4 minutes. All but about $10 \mathrm{~mL}$ was poured off, and the centrifuge vials were heated in an oven at $80^{\circ} \mathrm{C}$ overnight. Clean sample containers were labeled and weighed, the dried sediment was transferred to them, and the containers were reweighed.

Suspended-sediment concentrations were measured by dividing the dry weight of solid by the volume of water sampled. The suspended-sediment concentrations reported here are for grab samples of the fine fraction or washload portion of the suspended-sediment load and are almost certainly less than the cross-section-integrated suspended-sediment concentrations (U.S. Geological Survey, 1984). However, washload materials $(<0.063$-mm-diameter grains $)$ typically are dispersed relatively uniformly throughout the water column, and com- 
parison of the suspended-sediment (washload) concentrations between sampling sites during a single high-flow event and between different high-flow events should be acceptable.

A total of 24 samples of sediment from streambank and flood-plain settings, deposited during overbank flooding in February 1995 and February 1996, were collected in late February 1995 and in late March-early April 1996, respectively, after the floodwaters had receded. Samples of streambank or natural-levee deposits (within $200 \mathrm{ft}$ of the river's edge) were collected with a plastic trowel into labeled plastic bags. Samples of recent flood sediment were collected above a recognizable preflood surface, typically identified by a flattened-vegetation-mat horizon. Samples of marsh sediment, deposited during the February 1996 overbank flood, were collected from surfaces of vegetation, rocks, or fenceposts in late March and early April after the floodwaters had receded, into labeled plastic bags. Samples were dried for 24 hours in the drying oven at $80^{\circ} \mathrm{C}$. Streambank samples were pulverized in a chromium-steel ball mill to minus-200 mesh.

Samples were analyzed in the geochemical laboratory of Eastern Washington University, Cheney. For most samples, a 250-mg aliquot of the prepared sample was weighed in a Teflon beaker, except for some suspended-sediment samples for which the weight ranged from 25 to $250 \mathrm{mg}$. First, $2 \mathrm{~mL}$ of $\mathrm{HNO}_{3}$ and $1 \mathrm{~mL}$ of $\mathrm{HClO}_{4}$ was added to the sample, followed by heating until its volume was reduced to about half. Then $3 \mathrm{~mL}$ of $\mathrm{HF}$ and $5 \mathrm{~mL}$ of aqua regia was added to the sample, which was heated to dryness. Another $5 \mathrm{~mL}$ of aqua regia was added to the sample to completely break down any sulfide minerals. The sample was again heated to dryness, and the residue was dissolved in $4 \mathrm{~mL}$ of 1:1:2 $\mathrm{HCl}-\mathrm{HNO}_{3}-\mathrm{H}_{2} \mathrm{O}$ by gently warming the solution. Finally, the sample was diluted to a volume of $25 \mathrm{~mL}$ with distilled-deionized water, and the solution was transferred to a $60-\mathrm{mL}$ polyethylene bottle. Preparation blanks, duplicates, and reference standards were carried through the same procedure. Only Baker Instra-analyzed acids and high purity distilled-deionized water (similar to American Society for Testing and Materials type I water) were used throughout the digestion procedures and dilutions.

Contents of 28 elements (As, Ba, Be, Cd, Ce, Co, Cr, Cs, $\mathrm{Cu}, \mathrm{Ga}, \mathrm{K}, \mathrm{La}, \mathrm{Mo}, \mathrm{Ni}, \mathrm{P}, \mathrm{Pb}, \mathrm{Rb}, \mathrm{Sb}, \mathrm{Sn}, \mathrm{Sr}, \mathrm{Th}, \mathrm{Tl}, \mathrm{U}, \mathrm{V}, \mathrm{W}$, $\mathrm{Y}, \mathrm{Zn}$, and $\mathrm{Zr}$ ) were determined by inductively coupled plasma mass spectrometry (ICP-MS), using a Perkin-Elmer Sciex model 5000 instrument. For ICP-MS analyses, the sample solutions were further diluted by a factor of 10 with distilleddeionized water, and $\mathrm{Sc}, \mathrm{Rh}$, and Ho were used as internal standards. The concentration of $\mathrm{HCl}$ and $\mathrm{HNO}_{3}$ in final diluted solution was 0.4 volume percent. Contents of six elements ( $\mathrm{Al}, \mathrm{Ca}, \mathrm{Fe}, \mathrm{Mg}, \mathrm{Mn}$, and $\mathrm{Ti}$ ) were determined by inductively coupled plasma atomic-emission spectrometry (ICP-AES), using a Perkin-Elmer model ICP/6000 instrument. When $\mathrm{Pb}$ and $\mathrm{Zn}$ contents were high, the samples were reanalyzed by ICP-AES. Ag content was determined by using a flame atomic-absorption spectrophotometer, a Perkin-Elmer model 5000 instrument; a high-sensitivity nebulizer was used for determining low Ag contents.
The precision of these analyses is better than \pm 5 percent, established by duplicate analyses of numerous stream-sediment samples and reference standards. To estimate the accuracy of the chemical analyses, National Institute of Standards \& Technology (NIST) standard reference materials (SRM) 2710 and 2711 (Montana soils) and USGS reference standards GXR-2 and AGV-1 were analyzed with each batch of samples. The results obtained in this study for major and trace elements agreed closely with certified or recommended values. The contents of some elements, particularly $\mathrm{Ba}, \mathrm{Cr}$, $\mathrm{Ti}$, and $\mathrm{Zr}$, were about 5 to 10 percent lower, possibly owing to incomplete recovery of these refractory elements. The contributions from blanks were negligible; the contents of most elements in the blanks were below detection limits. Details concerning the accuracy and precision of the analyses of another sample set of stream sediment and streambank and marsh deposits from the drainage basin by the geochemical laboratory at Eastern Washington University were reported in Box and others (2001).

\section{Results}

Sampling sites for suspended sediment from the South Fork and main stem of the Coeur d'Alene River are located in figure 1 and from the Spokane River in figure 2, and sampling sites for overbank deposits from the South Fork and main stem of the Coeur d'Alene River are located in figure 3; corresponding analytical data are listed in tables 1 and 2. Some of the samples of suspended and marsh sediment collected from the February 1996 flood were examined by using scanning electron microscopy (SEM) to identify the various mineral phases that incorporate heavy metals (Robert Hooper, written commun., 1998). Most of the $\mathrm{Pb}$ and $\mathrm{Zn}$ observed in the samples with SEM is associated with amorphous Fe and Mn oxyhydroxide compounds as irregular grains or as surface coatings on other grains. A minor amount of $\mathrm{Pb}$ is carried as $\mathrm{Pb}$ carbonate (another weathering product of the original sulfide minerals) and as tiny $\mathrm{Pb}$ sulfide grains. A small but ubiquitous component of $\mathrm{Zn}$ sulfide grains is also present in most samples. In the original ores, these four metals occur primarily as sulfide and associated sulfur-bearing minerals (except Mn, which occurs as a major impurity in siderite [Fe carbonate], an uneconomic vein mineral; Fryklund, 1964). These sulfide minerals are unstable in oxygen- and water-rich surface soils, where they break down into their constituent elements and reprecipitate into more stable secondary phases (Balistrieri and others, 2003).

\section{Downstream Trends in Suspended-Sediment Concentration and Load}

Suspended-sediment concentrations (in weight of sediment per volume of water), as reported here, consist of the silt- and clay-size washload fraction of the total cross-section-integrated suspended-sediment concentration of Edwards and Glysson (1999); this fraction is generally considered to 
be evenly distributed throughout the channel cross section (Horowitz and others, 1990) and does not include sandier suspended material, which is concentrated near the streambed surface and decreases in concentration upward in the water column. Suspended-sediment loads (in tons of sediment moving past a particular sampling site per day) were estimated for the day of sampling at many of our sites by multiplying the measured suspended-sediment concentration by the mean daily streamflow (as extrapolated from nearby U.S. Geological Survey gaging-station data), using the appropriate units. The data used in these calculations are listed in table 3.

Suspended-sediment concentrations (fig. 10A) and loads (fig. 10B) during the February 1996 flood were much higher (by one and two orders of magnitude, respectively) than during either of the sampled 1997 high-flow events. Ignoring for a moment the two samples with sharply lower suspended-sediment concentrations collected at mi 24 and 38, suspended-sediment concentrations in 1996 increased downstream to a peak on the South Fork of the Coeur d'Alene River at Smelterville (mi 22) and gradually decreased farther downstream. In contrast, the suspended-sediment load peaked below the confluence of the North and South Forks of the Coeur d'Alene River (because of the much higher discharge below the confluence) and gradually decreased farther downstream. The two samples with anomalously lower suspended-sediment concentrations at mi 24 and 38 were collected in situations that may have resulted in the lower concentrations: the sample at mi 24 was collected about 20 hours after peak flow, when the river-surface elevation at that site had fallen $3.5 \mathrm{ft}$; the sample at mi 38 was collected at peak flow but along the upstream, distal edge of an overbank eddy about $100 \mathrm{ft}$ from the channel edge.

The downstream trends in suspended-sediment concentration and load on the Coeur d'Alene River during the waning flows on May 20, 1997, show similar patterns to those of the February 1996 trend but at lower values (figs. 10A, 10B). Suspended-sediment concentrations gradually increased from above Mullan downstream to Wallace (fig. 1), were nearly static in the South Fork of the Coeur d'Alene River below Wallace (with one unexplained anomalously low value at mi 12), and decreased abruptly below the confluence with the much larger North Fork (at mi 27). The suspended-sediment load gradually increased downstream from the South Fork into the main stem of the Coeur d'Alene River and remained at the same level farther downstream into the lower Coeur d'Alene River (fig. 10B).

Suspended sediment in the Spokane River was sampled twice during May 1997 high-flow event. In both sampling events, suspended-sediment concentrations in the Spokane River were very low relative to those in the South Fork and main stem of the Coeur d'Alene River (generally, the Spokane River was perceived as being "clear" during both sampling events), gradually increasing downstream between Coeur d'Alene Lake and Spokane Falls (downtown Spokane, fig. 2) and increasing more sharply below the muddy inflow of Latah Creek below Spokane Falls (mi 122). Sediment concentrations in the Spokane River on May 19-20 were higher than those on May 2. The suspended-sediment load on May 19-20 in the Spokane River at the lake outlet (peak flow) was about a third that on the Coeur d'Alene River (waning flow) and gradually increased downstream to values similar to, and even slightly larger than, those in the Coeur d'Alene River.

\section{Downstream Trends in the Metal Contents of Suspended Sediment}

In this section, we consider downstream trends in the contents of four mining-related elements $(\mathrm{Pb}, \mathrm{Zn}, \mathrm{Fe}$, and $\mathrm{Mn}$ ) in samples of suspended sediment collected during the 1996-97 high-flow events. Lead and zinc are relatively enriched in mined materials in the Coeur d'Alene Mining District and, when enriched in sediment, can significantly impact aquatic and human health. Iron and manganese are less enriched in sediment but play an important role as precipitated oxyhydroxide compounds onto which lead, zinc, and other metals sorb. Documenting the downstream compositional trends of these metals in suspended sediment is a first step toward understanding the sources and processes that control those compositions.

The elemental composition of suspended sediment changes along the flowpath of a stream by input from several sources, including (1) new material that is added from tributaries; (2) new material that is added by resuspension from, or subtracted by deposition onto, the streambed or flood plain of the stream; (3) new solids that are precipitated or dissolved in, or ions that are adsorbed from solution onto or desorbed into solution from, existing solids (as inflowing tributary or ground water mix into the stream, as conditions change within the stream, or by biologic processes); and (4) new material that is added by atmospheric fallout. During high-flow events, the first two sources are expected to be the most important; the second two sources may deposit materials in or on (or remove them from) the streambed and flood plain over a water year, affecting the mix of materials resuspended during subsequent high-flow events.

During suspended-sediment sampling on May 20, 1997, $\mathrm{Pb}$ and $\mathrm{Zn}$ contents increased downstream on the South Fork from upstream of Mullan (fig. 1) to its mouth and progressively decreased farther downstream along the main stem of the Coeur d'Alene River (fig. 11). Fe and Mn contents also generally increased downstream along the South Fork, with some subparallel irregularities along the way. Fe contents continued to increase farther downstream in the main stem of the Coeur d'Alene River, whereas Mn contents peaked just below the confluence of the North and South Forks and then decreased farther downstream in the main stem. All metal contents increased again in the Spokane River below the lake outlet, decreased just above Post Falls Dam (mi 92.3), and gradually increased downstream to Spokane Falls to values similar to or higher than those at Cataldo on the Coeur d'Alene River. During suspended-sediment sampling on May 2, 1997, metal contents were generally similar to, but lower than, those during peak flow on May 19-20. The sample collected farthest downstream on the Spokane River on May 2, 

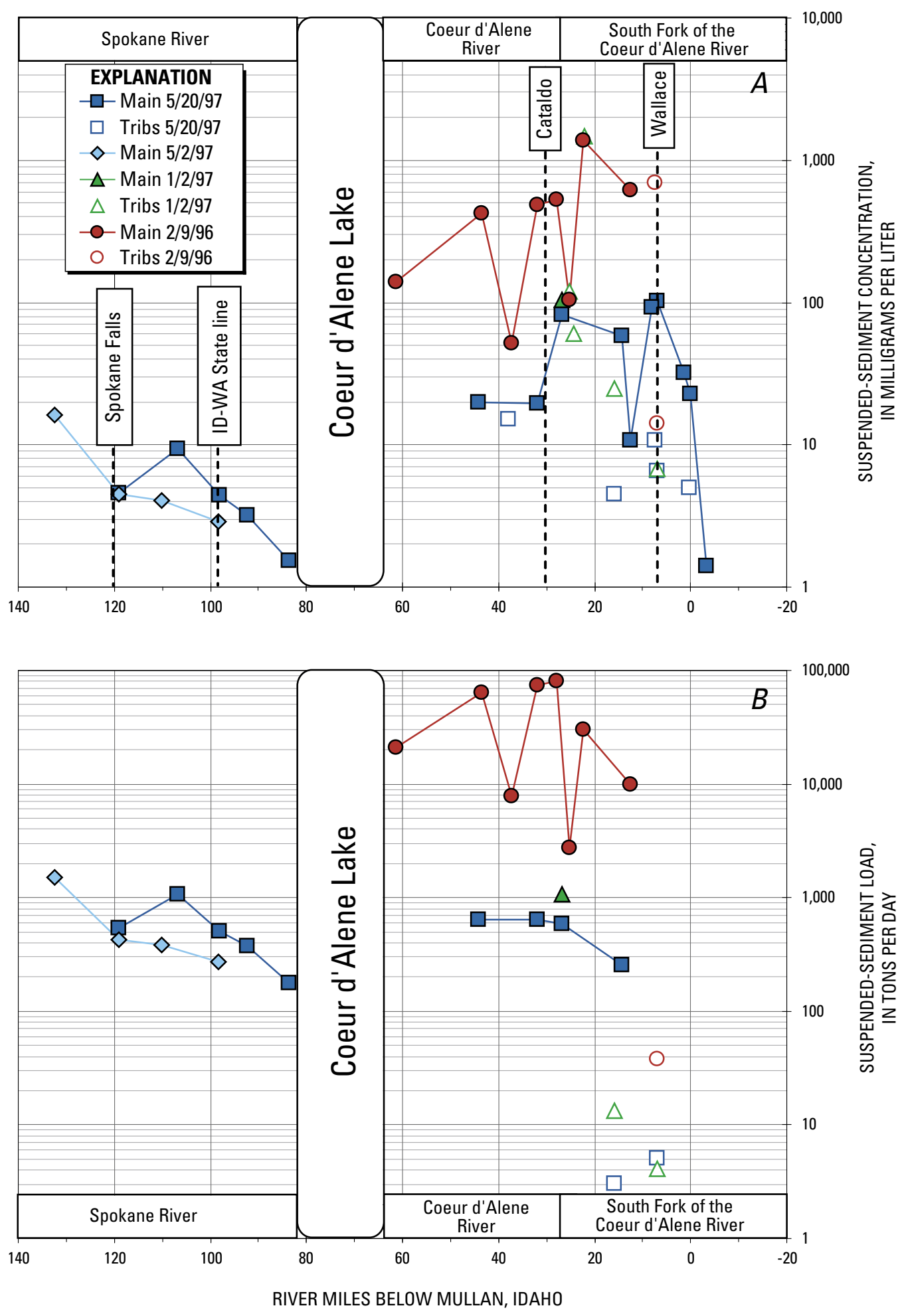

Figure 10. Suspended-sediment concentrations in grab samples collected from the South Fork of the Coeur d'Alene River, main stem of the Coeur d'Alene River, and the Spokane River ("main") and their tributaries ("tribs") $(A)$, and daily suspended-sediment loads at sampling sites for which mean daily streamflow could be extrapolated from nearby U.S. Geological Survey gaging stations $(B)$, versus downstream distance from Mullan, Idaho (see figs. 1 and 2 for locations), during high-flow events in 1996 and 1997. Tributary samples are plotted at downstream distance of tributary mouth from Mullan, Idaho. Data points for samples collected from "main" during a single high-flow event are connected by lines. See table 3 for analytical data. 
which had significantly lower $\mathrm{Pb}, \mathrm{Zn}$, and $\mathrm{Mn}$ contents but slightly higher Fe content, was apparently diluted by inflow of metal-poor suspended sediment from Latah Creek.

The downstream trend in the elemental composition of suspended sediment during the February 1996 flood shows a strikingly different pattern from that of the May 1997 flood (fig. 11). All metal contents except Zn were higher on the South Fork of the Coeur d'Alene River in the February 1996 flood, with a sharp peak at the Smelterville Bridge near the middle of the Bunker Hill Superfund site (mi 22.4, fig. 1). Metal contents reached a minimum at the sampling site on the Coeur d'Alene River just below Cataldo (mi 32.0, fig. 1). All metal contents in suspended sediment were considerably lower (except Fe, which was unchanged) at Cataldo in February 1996 than in May 1997 and were similar to those on the South Fork at Wallace from May 1997. Below Cataldo, metal contents gradually increased downstream to a sharp peak just above Coeur d'Alene Lake.
Samples of fine sediment coating marsh vegetation and other objects, collected after the recession of the February 1996 flood (fig. 3B; table 2), represent samples of suspended sediment accumulated over the period of flood-plain inundation, as opposed to the instantaneous samples collected from the water column during peak flow. Metal contents in this marsh sediment are compared with those in peak-flow suspended sediment in figure 11. Metal contents in a sample of 1996 marsh sediment at Cataldo (mi 32), where flood-plain inundation lasted about 1 day, were higher than in the corresponding sample of suspended sediment collected nearby during instantaneous peak flow. Metal contents in samples of 1996 marsh sediment below Cataldo, where flood-plain inundation lasted more than 2 weeks, varied widely, with a slightly lower range than in corresponding samples of the instantaneous-peak-flow suspended sediment collected near the same sites, and increased somewhat downstream.
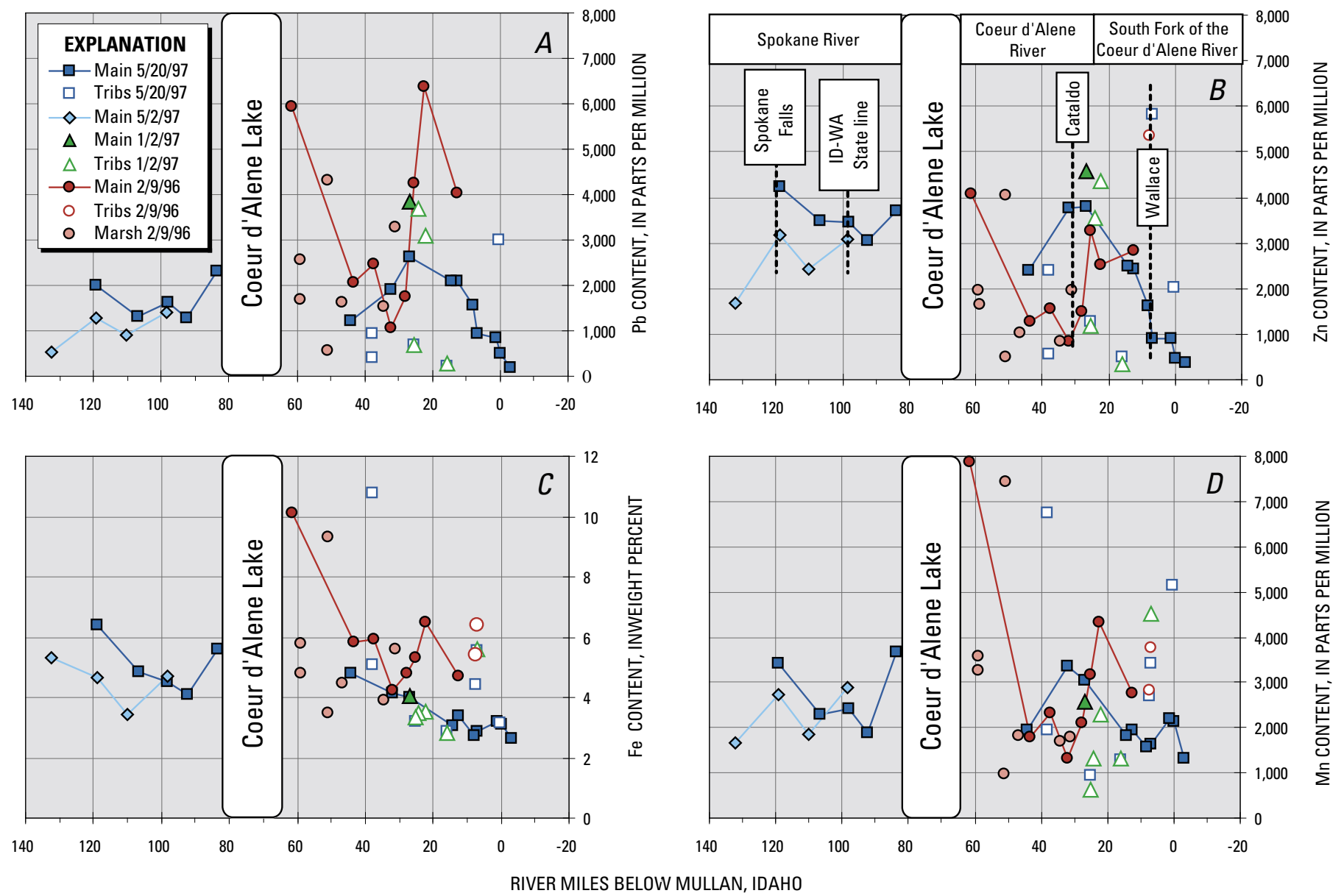

Figure 11. $\mathrm{Pb}(A), \mathrm{Zn}(B), \mathrm{Fe}(C)$, and $\mathrm{Mn}(D)$ contents in samples of suspended sediment collected from the South Fork of the Coeur d'Alene River, main stem of the Coeur d'Alene River, and the Spokane River ("main") and their tributaries ("tribs") and in samples of sediment deposited in flood-plain marshes versus downstream distance from Mullan, Idaho (see figs. 1 and 2 for locations and tables 1 and 2 for analytical data), during high-flow events in 1996 and 1997. Tributary samples are plotted at downstream distance of tributary mouth from Mullan, Idaho. Data points for samples collected from "main" during a single high-flow event are connected by lines. Note that in five samples collected from Canyon and Ninemile Creeks (near mi 7), Pb and, in three of these samples, $\mathrm{Zn}$ contents plot offscale. 
Samples of suspended sediment were also collected at the mouths of several tributaries during the February 1996, January 1997, and May 1997 floods. A few tributaries were sampled during more than one high-flow event. Canyon and Ninemile Creeks (fig. 1), major mining-impacted tributaries to the South Fork of the Coeur d'Alene River at Wallace (mi $6.8,7.7)$, were sampled during three and two high-flow events, respectively. In these tributaries, $\mathrm{Fe}$ and $\mathrm{Mn}$ contents were slightly higher, and $\mathrm{Pb}$ and $\mathrm{Zn}$ contents were significantly higher (generally plotting off scale on fig. 11; see table 1), than at the next downstream sampling site in the South Fork during each high-flow event. Comparing high-flow events at the same sampling sites, all metal contents were higher in the February 1996 flood than in the two 1997 floods except Zn, which was higher in the two 1997 floods.

Fe contents in suspended sediment from other tributaries (sampled in either or both of the 1997 high-flow events) were similar to those in 1997 samples from the adjacent reach of the Coeur d'Alene River (except the sample from the mouth of Fourth of July Creek at mi 37.9, which had a much higher Fe content; figs. 1, 11). $\mathrm{Pb}$ and $\mathrm{Zn}$ contents in samples of suspended sediment from three of these tributaries (Mill Creek, mi 0.4; Government Gulch, mi 21.7; Page Creek, mi 23.8) are higher, and from another three of these tributaries (Big Creek, mi 15.3; Pine Creek, mi 24.8; Fourth of July Creek, both upstream and at mouth, mi 38; fig. 11) much lower, than from the adjacent reach of the Coeur d'Alene River.

\section{Downstream Trends in the Metal Loads in Suspended Sediment}

Metal loads in suspended sediment (in pounds of metal in suspended sediment moving past a particular sampling site per day) were estimated for the day of sampling at many of our sites by multiplying the suspended-sediment load (in weight of sediment per day, as calculated in a previous section) by the $\mathrm{Pb}$ and $\mathrm{Zn}$ contents in that sample (table 3 ). The calculated metal loads must be considered only approximate because the instantaneous suspended-sediment concentration and metal content of that sample are implicitly assumed to represent daily averages when they are multiplied by the mean daily streamflow. However, these approximate values suffice to allow recognition of downstream trends in the metal loads in suspended sediment during a single high-flow event and to allow general comparisons between different high-flow events.

Calculated daily $\mathrm{Pb}$ and $\mathrm{Zn}$ loads in suspended sediment are plotted against distance along the river in figure 12 . The downstream changes in metal loads during a single high-flow event were small relative to the contrast between different high-flow events. Metal loads during the February 1996 flood were about 100 times larger than at corresponding sites during the May 1997 flood. During each high-flow event, $\mathrm{Pb}$ and $\mathrm{Zn}$ loads in suspended sediment increased by a factor of 3 or 4 downstream in the South Fork (fig. 1) from Osburn (mi 12) to its confluence with the North Fork (mi 27) and remained fairly constant downstream in the main stem of the Coeur d'Alene River during both events. Somewhat surprisingly, $\mathrm{Pb}$ and $\mathrm{Zn}$ loads in the Spokane River during peak flow on May 19-20, 1997 were nearly equivalent to those in the South Fork and main stem of the Coeur d'Alene River on May 20. However, because the samples of suspended sediment from the Coeur d'Alene River were collected 4 days after peak flow on that reach, we suspect that the metal loads in suspended sediment on that reach were at least somewhat higher during peak flow. $\mathrm{Pb}$ and $\mathrm{Zn}$ loads in suspended sediment in the Spokane River during peak flow on May 19-20, 1997, were more than double those during the earlier, lower peak flow on May 2.

The downstream increases in suspended-sediment and metal loads in the Spokane River during the two sampling periods in 1997 indicate that a significant proportion of the metal load is being progressively mobilized out of the Spokane River streambed sediment. At $20 \mathrm{mi}$ below the lake outlet, about 70 percent of the $\mathrm{Pb}$ load and more than 80 percent of the $\mathrm{Zn}$ load in suspended sediment in the Spokane River was derived from sediment in its bed, overwhelming the suspended component that transited the lake from the Coeur d'Alene River.

\section{Downstream Trends in the Metal Contents of Streambank Flood Deposits}

After the February 1995 flood and again after the February 1996 flood, samples of newly deposited flood sediment were collected along the flanks of the river channel after high water had subsided. Unlike the very fine grain size of the washload suspended-sediment samples discussed above, these samples typically consisted of fine sand but ranged in grain size from silt to coarse sand (table 2). After the February 1995 flood, samples of sediment deposited on the streambank by the flood were collected for several miles both upstream and downstream of the gradient break in the Coeur d'Alene River below Cataldo (figs. 1, 3A). After the February 1996 flood, streambank flood deposits were sampled along a 40-mi reach from near Kellogg on the South Fork of the Coeur d'Alene River nearly to the delta of the Coeur d'Alene River into Coeur d'Alene Lake (fig. 3A). Analyses of unfractionated samples of the 1995 and 1996 streambank flood deposits are listed in table 2.

In the more extensive sampling of streambank deposits after the February 1996 flood (fig. 3B), metal contents gradually decrease from near Kellogg on the South Fork (fig. 13) to Cataldo on the main stem of the Coeur d'Alene River, and sharply increase beginning a few miles below Cataldo. Over a 4-mi reach centered on mi 36 (fig. 13), $\mathrm{Pb}$ and Fe contents more than double, while $\mathrm{Zn}$ and Mn contents more than quadruple. Metal contents similarly increase downstream over the same reach after February 1995 flood, with nearly identical values. Metal contents peak near mi 40 in the 1996 streambank deposits and decrease downstream somewhat to the delta into Coeur d'Alene Lake (though still well above values at Cataldo).

Metal contents in the fine ( $<2-\mathrm{mm}$ grain size) fraction of samples of streambed sediment collected on the South 


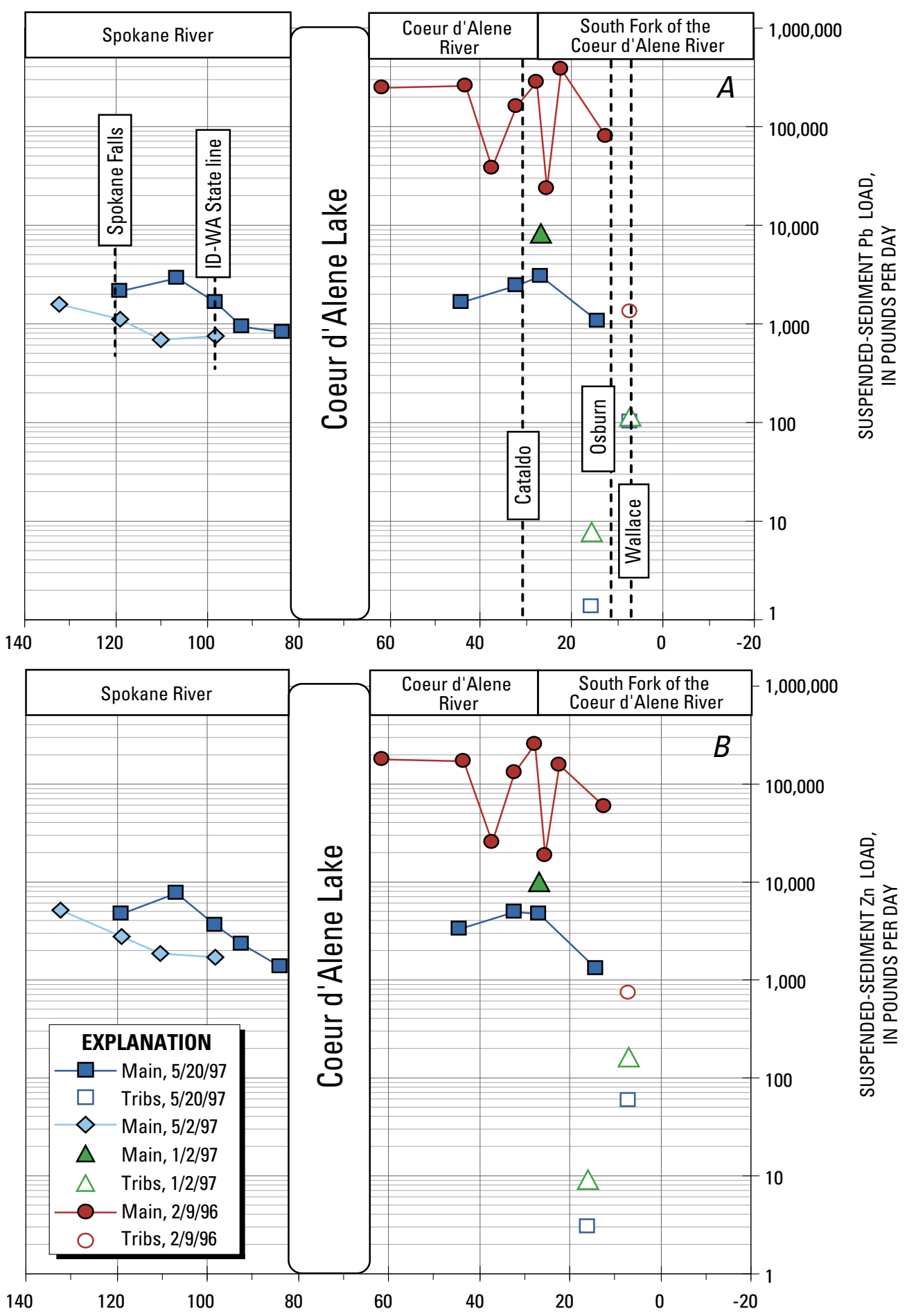

RIVER MILES BELOW MULLAN, IDAHO

Figure 12. Calculated daily loads of $\mathrm{Pb}(A)$ and $\mathrm{Zn}(B)$ in suspended sediment at selected sampling sites versus downstream distance from Mullan, Idaho (see figs. 1 and 2 for locations), during high-flow events in 1996 and 1997. Daily metal loads were calculated by using measured suspended-sediment concentration, $\mathrm{Pb}$ and $\mathrm{Zn}$ contents in each sample, and daily mean flow at that sampling site, extrapolated from daily mean streamflows measured at nearby U.S. Geological Survey gaging stations (see data listed in table 3). Samples collected along main channel ("main") during February 1996 (red), early May 1997 (light blue), and late May 1997 (dark blue) are connected by colored lines. 
Fork and main stem of the Coeur d'Alene River in 1993 and 1994 (Box and others, 2001) are also plotted in figure 13. Pb and $\mathrm{Zn}$ contents in the streambed sediment samples closely correspond to those in the 1995 and 1996 streambank flood deposits at adjacent sites. Fe and Mn contents in samples of streambed sediment are nearly identical to those in adjacent streambank deposits below Cataldo but differ markedly above. Specifically, Fe and Mn contents in samples of streambed sediment between mi 20 and 30 are much higher than in 1996 streambank flood deposits. The close similarity in the metal contents of the 1995 and 1996 streambank flood deposits to those of adjacent streambed sediment below Cataldo strongly suggests that streambank flood deposits were derived from mobilized streambed sediment in the adjacent channel (fig. 14). Although the similarity in the $\mathrm{Pb}$ and $\mathrm{Zn}$ contents of the streambank deposits and adjacent streambed sediment above Cataldo also suggests such a derivation, their contrasts in $\mathrm{Fe}$ and Mn contents suggest that other processes or sources must also be important over that reach.
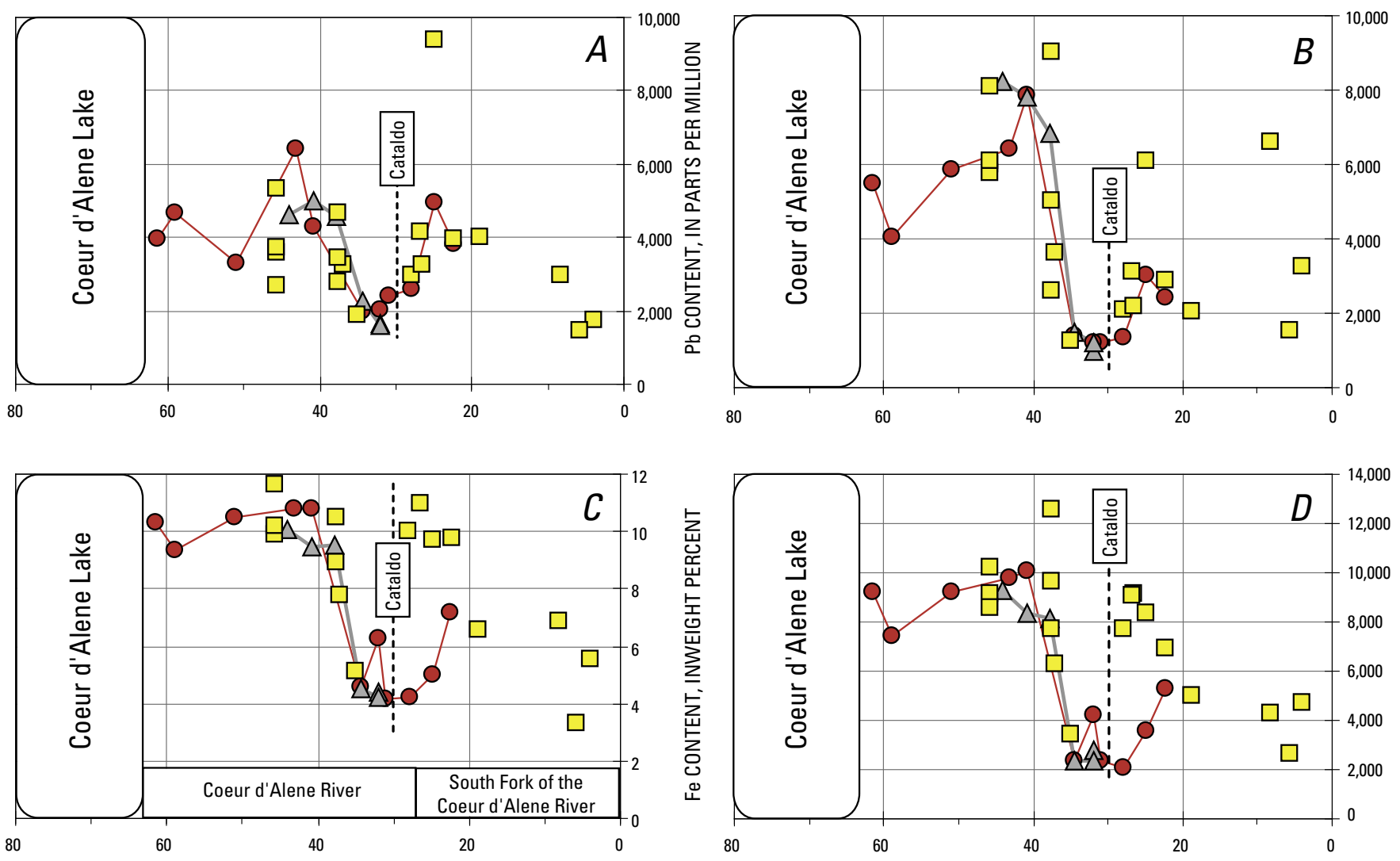

RIVER MILES BELOW MULLAN, IDAHO

Figure 13. $\mathrm{Pb}(A), \mathrm{Zn}(B), \mathrm{Fe}(C)$, and $\mathrm{Mn}(D)$ contents in samples of streambank sediment deposited along the South Fork and main stem of the Coeur d'Alene River versus downstream distance from Mullan, Idaho (see fig. 3 for locations), during February 1995 and February 1996 high-flow events. Data points for samples of sediment deposited on streambank during high-flow events of February 1995 (gray triangles) and February 1996 (red circles) are connected by colored lines. Yellow squares, samples of streambed sediment collected from river channel in 1993 and 1994 (Box and others, 2001). Similarity of downstream progression in metal contents of streambank deposits from the two floods, as well as their similarity to those of adjacent streambed sediment, suggests that streambank sediment deposited during each flood was mobilized from sediment in adjacent streambed. 
The four river reaches are (1) tributaries to the South Fork of the Coeur d'Alene River, including the South Fork above Wallace; (2) the South Fork of the Coeur d'Alene River below Wallace; (3) the main stem of the Coeur d'Alene River, and (4) the Spokane River (figs. 1-3). Samples of streambank flood deposits are subdivided into those from the South Fork, those on the main stem of the Coeur d'Alene River above Cataldo, and those on the main stem below the abrupt flattening of the stream gradient a few miles below Cataldo.

In the following discussion, we compare the interelement correlations in samples from subsets of these sample groups. On the accompanying element-element scatterplots (figs. 15-17), regression lines are calculated for selected data subsets by river reach and, for some samples, by year as well. Regression lines on the plots were calculated by the least-squares method, and coefficients of determination $\left(R^{2}\right)$ are listed; however, given the generally small size of the data subsets (mostly less than 25 samples, some as small as 8 samples), the statistical significance of some of these apparent correlations is uncertain. Nonetheless, the consistent contrasts in the correlation trends between selected data subsets argue strongly for their general distinction.

Fe and Mn correlate strongly $\left(R^{2}=0.86\right)$ in all samples (fig. $15 A)$. The Fe contents of all samples separate into two clusters: (1) samples containing from 9 to 11 weight percent Fe (mostly streambank flood sediment from the lower Coeur d'Alene River below Cataldo), and (2) samples containing from 3 to 7 weight percent Fe (all other samples). The linear regression line for this correlation trends toward a point at $0 \mathrm{ppm} \mathrm{Mn}$ and about 2 weight percent $\mathrm{Fe}$, apparently reflecting a sedimentary mixture of two Fe compounds in the sediment: in a form unassociated with Mn (2 weight percent Fe in all samples), and in association with Mn. We infer that the association of Fe with Mn represents Fe and Mn oxyhydroxide compounds produced from weathering of tailings-contaminated sedimentary deposits in the valley and from interaction of ground and surface waters (Horowitz and others, 1993; Balistrieri and others, 2003).

$\mathrm{Zn}$ and $\mathrm{Pb}$ correlate crudely in all the samples of flood sediment $\left(R^{2}=0.62\right.$; regression line not shown in fig. $\left.15 B\right)$, but better correlations result from clustering the sample set into three subsets: (1) samples with Zn less than Pb contents (mostly 1996 samples, including suspended sediment from the South Fork and main stem of the Coeur d'Alene River, marsh flood sediment from the Coeur d'Alene River valley, and both 1995 and 1996 streambank flood deposits from the South Fork and main stem of the Coeur d'Alene River above Cataldo; (2) samples with $\mathrm{Zn}$ about equal to $\mathrm{Pb}$ contents (1996 and 1997 suspended sediment from tributaries to the South Fork of the Coeur d'Alene River, and 1997 suspended sediment from the South Fork); and (3) samples with Zn greater than Pb contents (mostly 1997 samples, including suspended sediment from the Coeur d'Alene and Spokane Rivers, but also 1995 and 1996 streambank flood deposits from the Coeur d'Alene River below Cataldo). A $t$ test indicates that the differences between the three subsets are statistically significant. The first subset defines a linear regression line $\left(R^{2}=0.86\right)$ that trends toward the origin $(0 \mathrm{ppm} \mathrm{Zn}$ and $0 \mathrm{ppm}$ $\mathrm{Pb}$ ) and has the shallowest slope (that is, the smallest increase in $\mathrm{Zn}$ content relative to increasing $\mathrm{Pb}$ content), and the third subset defines a linear regression line $\left(R^{2}=0.75\right)$ that trends toward a point at 1,790 ppm $\mathrm{Zn}$ and $0 \mathrm{ppm} \mathrm{Pb}$ and has the steepest slope. The second subset defines a linear regression line $\left(R^{2}=0.72\right)$ intermediate between the other two, trending toward a point at $680 \mathrm{ppm} \mathrm{Zn}$ at $0 \mathrm{ppm} \mathrm{Pb}$. These relations suggest the presence of a sedimentary component with $\mathrm{Zn}$ but no $\mathrm{Pb}$ content in the second and third sample subsets (discussed further below).

The relations of $\mathrm{Pb}$ and $\mathrm{Zn}$ to $\mathrm{Fe}$ and $\mathrm{Mn}$ are complex, as shown in figures 16 and 17 . For the entire sample set, $\mathrm{Pb}$ and Fe correlate poorly $\left(R^{2}=0.14\right)$, but better correlations result from dividing the sample set into three subsets by river reach, regardless of year (fig. 16A): (1) suspended sediment $(n=16)$ from tributaries to the South Fork of the Coeur d'Alene River (high $\mathrm{Pb} / \mathrm{Fe}$ ratios; $R^{2}=0.94$ ), (2) suspended and streambank flood sediment $(n=9)$ from the South Fork of the Coeur d'Alene River (moderate $\mathrm{Pb} / \mathrm{Fe}$ ratios; $R^{2}=0.94$, when sample outlier of streambank sediment with 7.2 weight percent $F e$ is omitted), and (3) suspended, streambank, and marsh sediment $(n=38)$ from the main stem of the Coeur d'Alene River and suspended sediment from the Spokane River (low $\mathrm{Pb} / \mathrm{Fe}$ ratios; $\left.R^{2}=0.80\right)$. The regression lines radiate from a point at

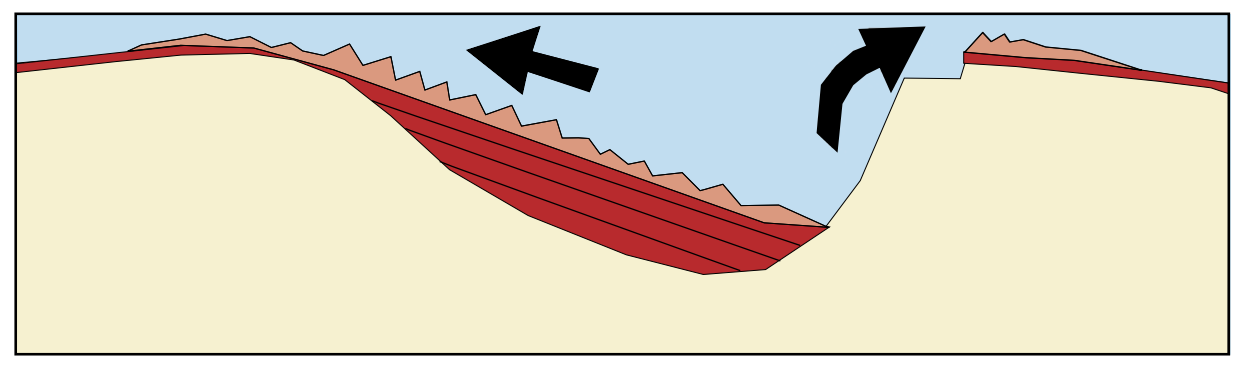

Figure 14. Schematic cross section of river channel and natural levee during overbank flooding. Blue, floodwater; pink-dotted unit, sandy material entrained along riverbed; red layered unit, historical metal-enriched sedimentary deposits; yellow layer, premining unconsolidated deposits. Sandy material deposited on channel margin and levee top during overbank flood is mobilized from (and is similar in elemental composition to) adjacent streambed sediment and is deposited as water velocities decrease along channel flanks. 

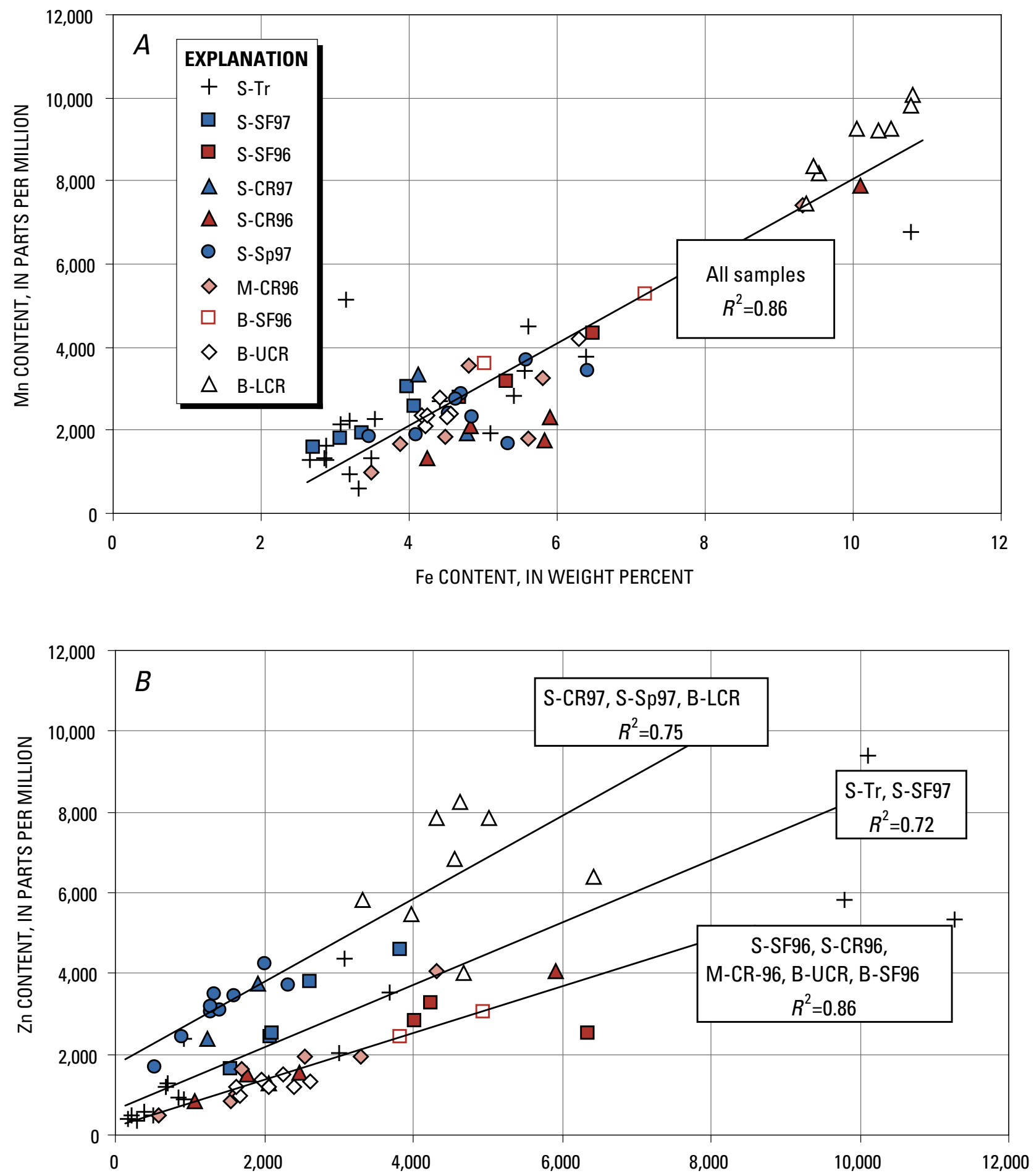

Pb CONTENT, IN PARTS PER MILLION

Figure 15. Mn versus Fe contents $(A)$ and $\mathrm{Zn}$ versus $\mathrm{Pb}$ contents $(B)$ in flood-sediment samples grouped by sample media, river reach, and flood year. Sample media: $B-$, streambank sediment; $\mathrm{M}-$, marsh sediment; $\mathrm{S}_{-}$, suspended sediment. River reaches: CR, main stem of the Coeur d'Alene River; LCR, lower main stem of the Coeur d'Alene River, downstream from Cataldo; SF, South Fork of the Coeur d'Alene River; Sp, Spokane River; Tr, tributary to the South Fork of the Coeur d'Alene River; UCR, upper main stem of the Coeur d'Alene River, from Cataldo upstream. Year (combined if not designated): 96,$1996 ; 97,1997$. Data points for two tributary samples with more than $12,000 \mathrm{ppm} \mathrm{Pb}$ and (or) Zn plot outside area of figure 15B. Linear-regression lines and coefficients of determination $\left(R^{2}\right.$, calculated by least-squares method) are for samples clustered by year and river reach into three subsets as listed in figure $15 B$. 


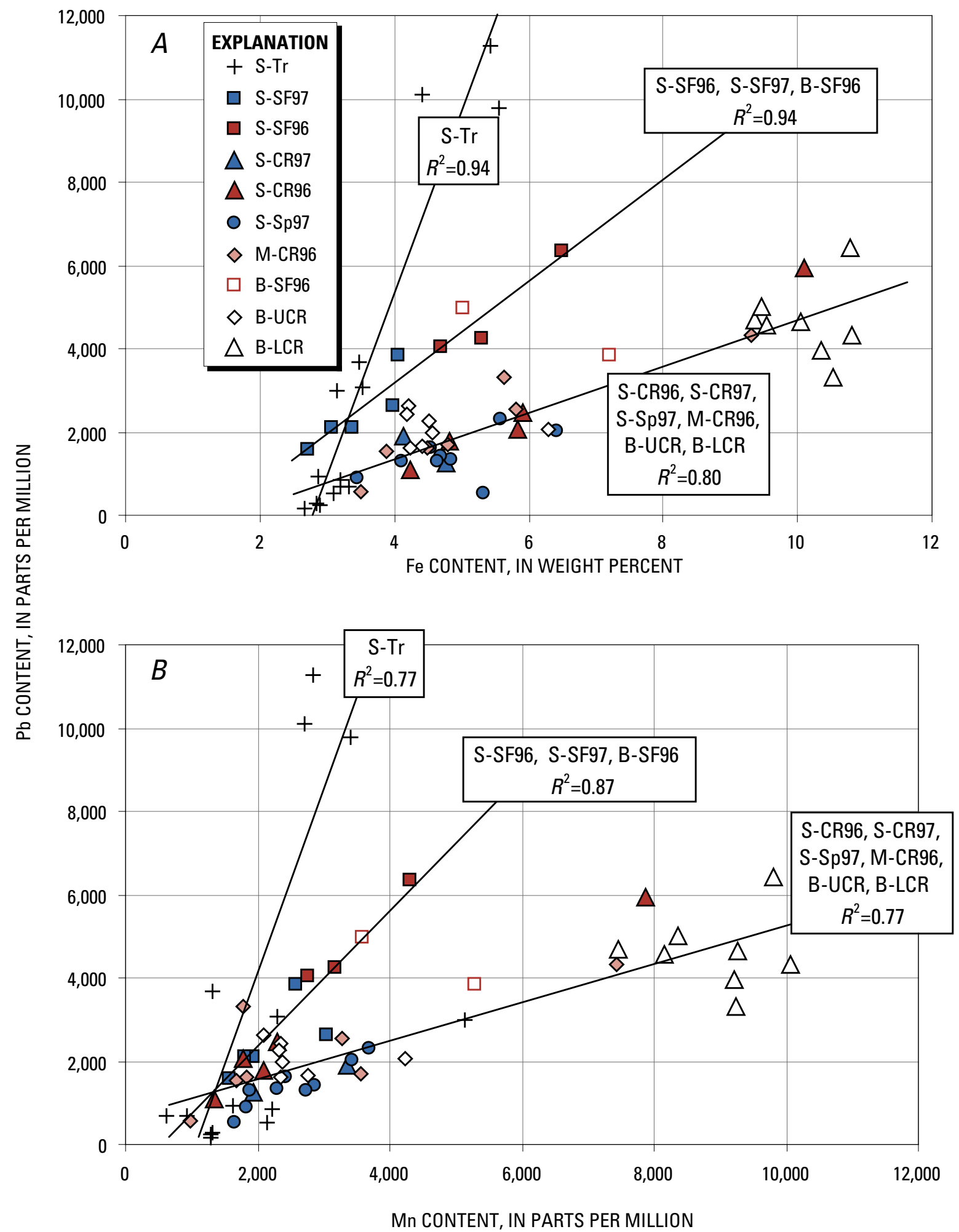

Figure 16. $\mathrm{Pb}$ versus $\mathrm{Fe}$ contents $(A)$ and $\mathrm{Pb}$ versus $\mathrm{Mn}$ contents $(B)$ in flood-sediment samples grouped by sample media, river reach, and flood year. Same symbols and abbreviations as in figure 15; see figures 1 and 2 for locations. Linear-regression lines and coefficients of determination $\left(R^{2}\right.$, calculated by least-squares method) are for samples clustered by river reach (regardless of year) into three subsets as listed. Sample B-SF96 outlier with 7.2 weight percent $\mathrm{Fe}$ and $5,280 \mathrm{ppm} \mathrm{Mn}$ was not used in regression calculation. Data points for two tributary samples that contain more than $12,000 \mathrm{ppm} \mathrm{Pb}$ plot outside area of figures. 


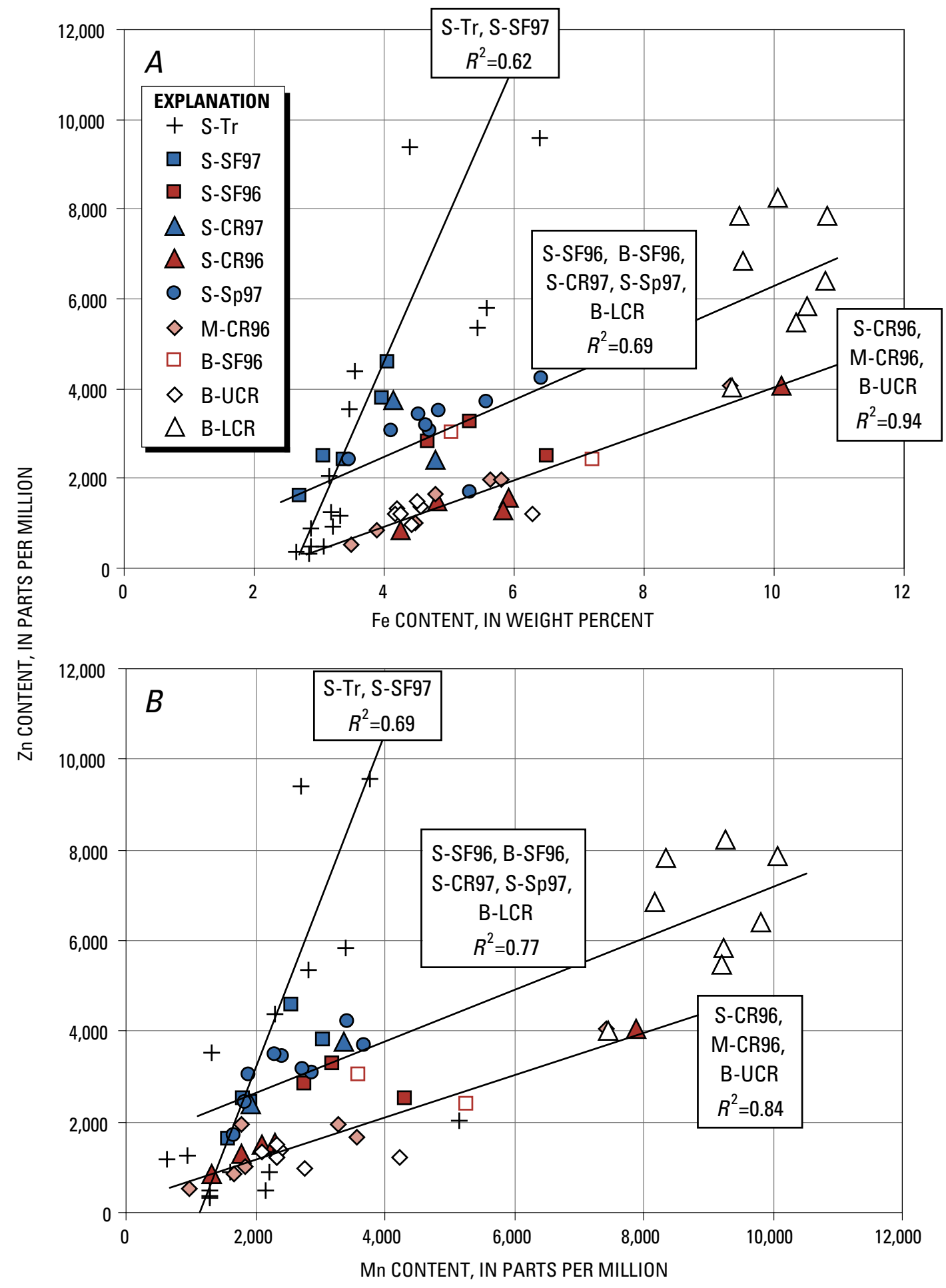

Figure 17. $Z n$ versus Fe contents $(A)$ and $Z n$ versus $M n$ contents $(B)$ in samples grouped by sample media, river reach, and flood year. Same symbols and abbreviations as in figure 15; see figures 1 and 2 for locations. Linear-regression lines and coefficients of determination $\left(R^{2}\right.$, calculated by leastsquares method) are for samples separated by river reach into three subsets as in figure 16, except for 1997 suspended samples and lower Coeur d'Alene River streambank samples, which correlate with next upstream subset (that is, 1997 samples from the South Fork of the Coeur d'Alene River correlate with tributary samples, and 1997 samples from the Spokane River and main stem of the Coeur d'Alene River correlate with 1996 samples from the South Fork of the Coeur d'Alene River). Data points for two tributary samples that contain more than 12,000 ppm Zn plot outside area of figures. 
0 ppm $\mathrm{Pb}$ and about 2.0 to 2.5 weight percent $\mathrm{Fe}$. $\mathrm{Pb}$ and $\mathrm{Mn}$ correlate well in the same three sample subsets (fig. 16B), with regression lines radiating from closer to the origin $(0 \mathrm{ppm} \mathrm{Pb}$ and 0-1,000 ppm Mn). Similar correlations of $\mathrm{Pb}$ with $\mathrm{Fe}$ and Mn by reach along the Coeur d'Alene-Spokane River system provide strong supporting evidence that $\mathrm{Pb}$ is associated with $\mathrm{Fe}$ and $\mathrm{Mn}$ mineral compounds, suggesting that this association changes stepwise in a downstream direction (that is, from tributaries to the South Fork, to the South Fork itself, and finally into the main stem of the Coeur d'Alene River, continuing through Coeur d'Alene Lake into the Spokane River) to account for the stepwise changes in geochemical correlations.

Because $\mathrm{Zn}$ and $\mathrm{Pb}$ correlate differently for samples from the 1996 versus the 1997 floods (fig. 15B), the sample subsets (by river reach) used for correlations of $\mathrm{Zn}$ to $\mathrm{Fe}$ and $\mathrm{Mn}$ in figure 17 are modified somewhat from those used for $\mathrm{Pb}$ in figure 16. The 1997 suspended-sediment sample groups and the sample group of all streambank flood deposits from the lower Coeur d'Alene River are each correlated with the next upstream sample subset. For example, the 1997 South Fork suspended-sediment samples, which clustered with 1996 South Fork suspended-sediment samples at moderate $\mathrm{Pb} / \mathrm{Fe}$ and $\mathrm{Pb} / \mathrm{Mn}$ ratios in figure 16 , correlate with the tributary samples at high $\mathrm{Zn} / \mathrm{Fe}\left(R^{2}=0.62\right)$ and $\mathrm{Zn} / \mathrm{Mn}\left(R^{2}=0.69\right)$ ratios in figure 17 . Likewise, the samples of 1997 suspended sediment from the Coeur d'Alene and Spokane Rivers and all streambank flood deposits from the lower Coeur d'Alene River, which clustered with 1996 Coeur d'Alene River samples at low $\mathrm{Pb} / \mathrm{Fe}$ and $\mathrm{Pb} / \mathrm{Mn}$ ratios in figure 16 , correlate with 1996 South Fork samples at moderate $\mathrm{Zn} / \mathrm{Fe}\left(R^{2}=0.69\right)$ and $\mathrm{Zn} / \mathrm{Mn}\left(R^{2}=0.77\right)$ ratios in figure 17 . In figures $17 A$ and $17 B$, the regression lines for the sample subset including the 1997 Coeur d'Alene and Spokane River suspended sediment nearly parallel those for the sample subset including the 1996 Coeur d'Alene suspended and marsh sediment but are higher by 1,500 to 2,000 ppm $\mathrm{Zn}$ at a given $\mathrm{Fe}$ or Mn content. These trends (along with those in fig. $15 B$ ) suggest that 1,500 to $2,000 \mathrm{ppm}$ of the $\mathrm{Zn}$ in the 1997 Coeur d'Alene and Spokane River suspended sediment and in streambank flood deposits along the lower Coeur d'Alene River is not associated with $\mathrm{Fe}$ and $\mathrm{Mn}$.

Several previous studies in the Coeur d'Alene-Spokane River system have also suggested the presence of a sedimentary component of particulate $\mathrm{Zn}$ that is not strongly associated with Fe, Mn, or Pb. Paulson (2001) found that dissolved $\mathrm{Zn}$ is progressively lost from river water downstream in the Coeur d'Alene River below Cataldo, apparently by sorption onto organic particulates, which accumulate in the streambed sediment. Similarly, Box and Wallis (2002) identify a high$\mathrm{Zn}$, low-Pb component in streambed sediment in the Spokane River that they suggest is derived by precipitation of $\mathrm{Zn}$ in new particles or by sorption of $\mathrm{Zn}$ onto existing particles. Balistrieri and others (2003) showed that dissolved $\mathrm{Zn}$ is lost during mixing of Zn-rich ground waters with Coeur d'Alene River water, either by sorption onto existing Fe-rich particles or by precipitation of Fe-rich flocculants. We suggest that the process of sorption of dissolved $\mathrm{Zn}$ from river water onto existing organic or inorganic particles contributes the sedimen- tary component of $\mathrm{Zn}$, which is apparently not associated with $\mathrm{Fe}, \mathrm{Mn}$, or $\mathrm{Pb}$, to the sources of the 1997 suspended sediment in the Coeur d'Alene and Spokane Rivers and of the streambank flood sediment along the lower Coeur d'Alene River.

Several other mining-related elements consistently correlate with either $\mathrm{Zn}$ or $\mathrm{Pb}$, although the samples of suspended sediment from the Spokane River commonly are somewhat distinct from those the Coeur d'Alene River and tributaries (figs. 1, 2). Cd correlates well with $\mathrm{Zn}$ (fig. 18A), with a weight ratio of about 5:1,000. Both $\mathrm{Ag}$ and $\mathrm{Sb}$ correlate well with $\mathrm{Pb}$ (figs. $18 B, 18 C$ ), with weight ratios of $3: 1,000$ and 10:1,000, respectively, although the samples of suspended sediment from the Spokane River have weight ratios consistently different from (about half) those from the Coeur d'Alene River and its tributaries. Ag consistently correlates with $\mathrm{Sb}$ $\left(R^{2}=0.83\right)$ in all samples (fig. $\left.18 D\right)$ with a weight ratio of $1: 4$.

Correlations between some of the mining-related elements are weak or nonexistent. Arsenic broadly correlates with Fe in all the samples $\left(R^{2}=0.64\right)$, but within-group trends are generally scattered (fig. $18 E$ ). Cu correlates poorly with all other mining-related elements, as illustrated by a plot of $\mathrm{Cu}$ versus $\mathrm{Fe}$ contents (fig. 18F). $\mathrm{Cu}$ contents in many of the samples of tributary suspended sediment and in some of the samples of Spokane River suspended sediment are anomalously high relative to enrichments in other mining-related elements.

\section{Discussion}

\section{Sources of Metal-Enriched Sediment Mobilized During Flooding and the Processes Responsible for Elemental Distributions}

The geographic and temporal variations in mining-related elemental composition and in interelemental correlations in flood sediment in the Coeur d'Alene-Spokane River system (figs. 1, 2) result from corresponding variations in the sediment sources and their characteristics. The ultimate sources of the metal-enriched materials are the ore deposits of the Coeur d'Alene Mining District, in which the $\mathrm{Pb}, \mathrm{Zn}, \mathrm{Cd}, \mathrm{Ag}, \mathrm{Cu}, \mathrm{As}, \mathrm{Sb}$, and some of the $\mathrm{Fe}$ are held in sulfidic minerals, while the Mn and some of the Fe are held in carbonate gangue minerals (Fryklund, 1964). Once these ores are extracted from the deep subsurface and placed in the oxidizing surface environment, the primary ore and gangue minerals begin to weather and are gradually replaced by secondary compounds, which consist of various oxide, carbonate, phosphate, sulfate, and sulfide minerals (Fryklund, 1964; Hooper and Mahoney, 2000). Many of the primary minerals in the approximately 62 million tons of mine-waste materials that were disposed of into the South Fork of the Coeur d'Alene River and its tributaries between 1886 and 1968 (Long, 1998) have subsequently weathered into these secondary compounds. The overall strong correlations of mining-related elements with Fe and $\mathrm{Mn}$ in flood-sediment samples, along with the spatial association 

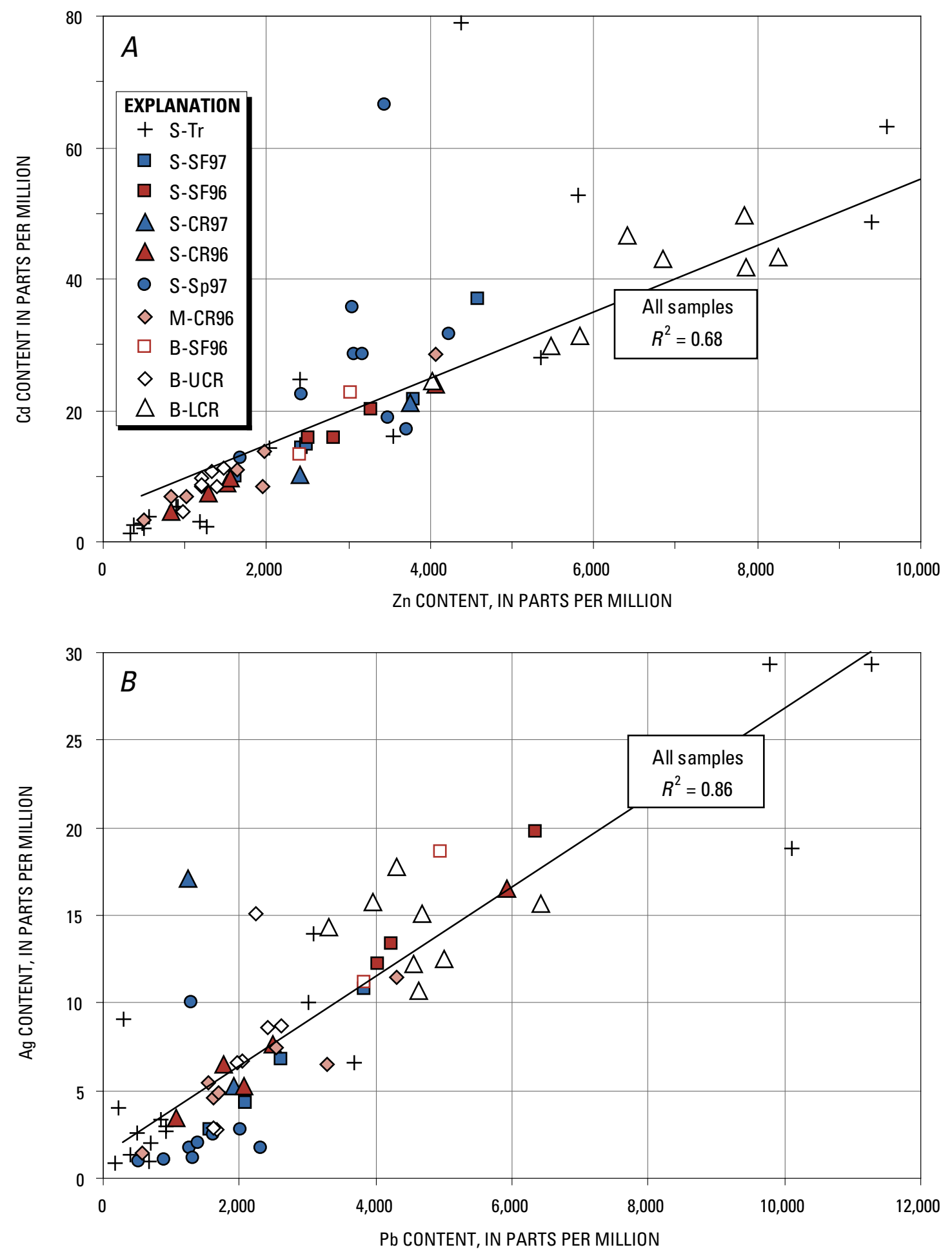

Figure 18. Cd versus $\mathrm{Zn}$ contents $(A)$, Ag versus $\mathrm{Pb}$ contents $(B), \mathrm{Sb}$ versus $\mathrm{Pb}$ contents $(C)$, Ag versus $\mathrm{Sb}$ contents $(D)$, As versus $F e$ contents $(E)$, and $C u$ versus $F e$ contents $(F)$ in flood-sediment samples grouped by sample media, river reach, and flood year, showing linear-regression lines for all samples and coefficients of determination ( $R^{2}$, calculated by least-squares method). Same symbols and abbreviations as in figure 15; see figures 1 and 2 for locations. Data points for two tributary samples that contain more than $10,000 \mathrm{ppm}$ Zn plot outside area of $18 A$; data points for two tributary samples that contain more than $12,000 \mathrm{ppm}$ Pb plot outside area of figure $18 B$; data points for three tributary samples that contain more than $100 \mathrm{ppm} \mathrm{Sb}$ and (or) more than 12,000 ppm Pb plot outside area of figure $18 C$; and data points for two tributary samples that contain more than $200 \mathrm{ppm}$ As plot outside area of figure $18 \mathrm{E}$ and were not used in regression calculation. 

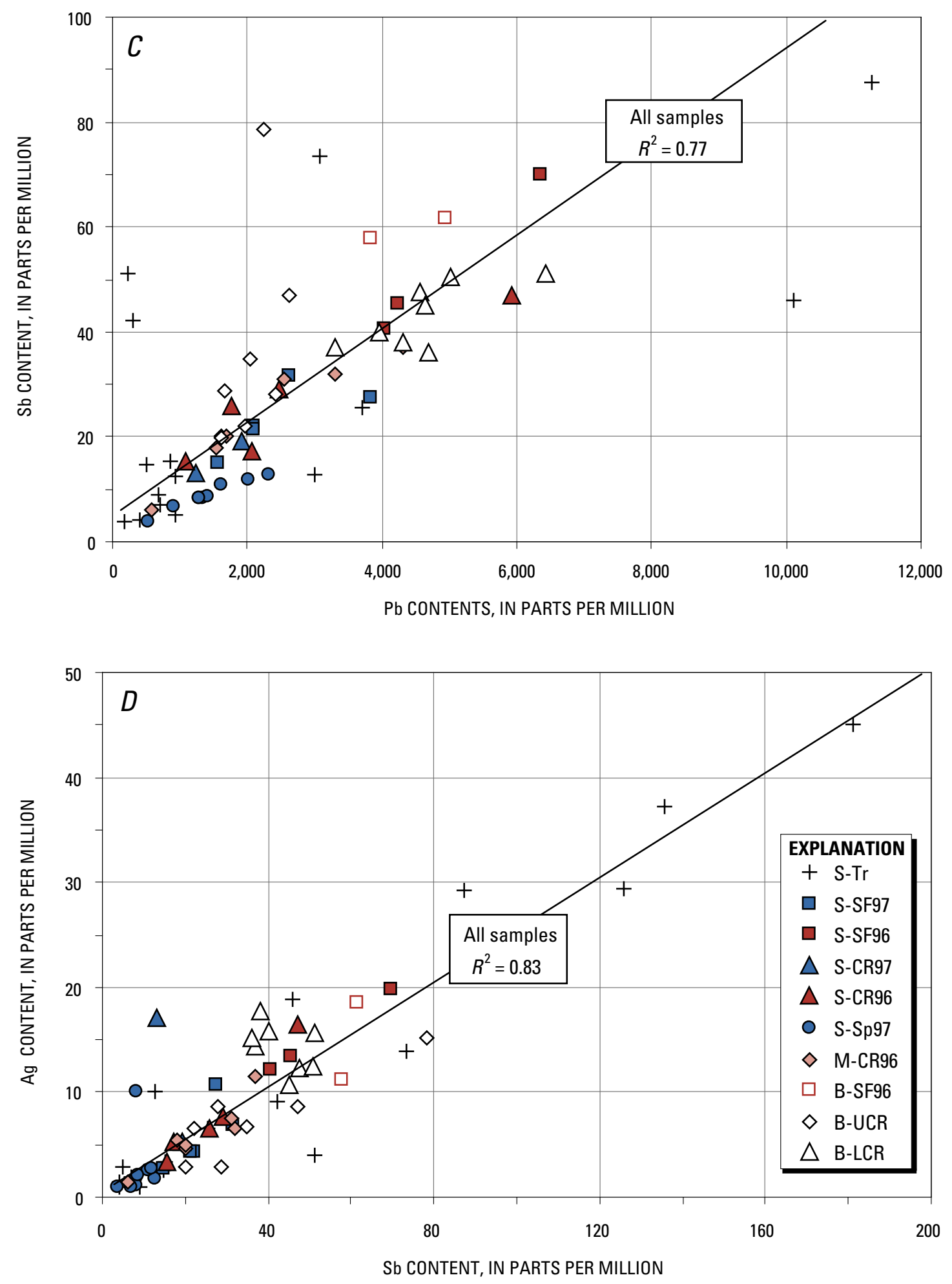

Figure 18. Continued. 

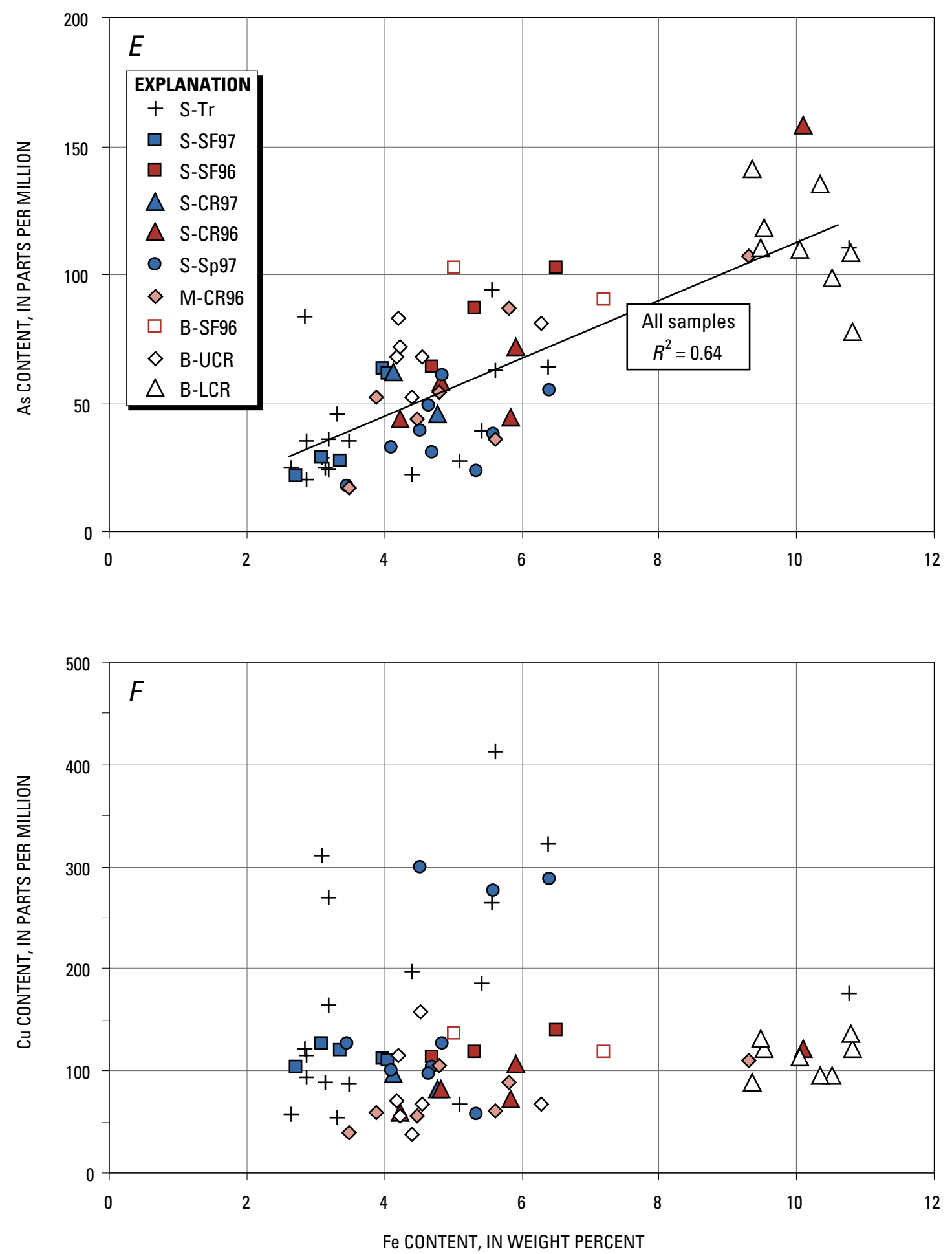

Figure 18. Continued. 
of those elements in SEM backscatter images, indicate a strong mineralogic association of $\mathrm{Pb}, \mathrm{Zn}$, and other mining-related elements with secondary Fe and Mn oxyhydroxide phases. The varying processes of weathering, transport, and depositional storage of the mining-related materials are presumed to lead to geochemical variations in sediment sources and their characteristics. In the following discussion, we identify potential sources of the flood sediment and consider some implications of the varying source mixtures that are required to produce the geographic and temporal variations in the geochemistry of flood sediment.

A large dataset of chemical analyses of potential flood-sediment source materials is available for the South Fork and main stem of the Coeur d'Alene River (Abraham, 1994; Fousek, 1996; McCulley and others, 1995; Golder Associates, 1996; Paulson and others, 1996; Terragraphics Environmental Engineering, Inc., 1996; Box and others, 2001). Because many of the analyses of South Fork materials consist of data for only $\mathrm{Pb}$ and $\mathrm{Zn}$, we compare only these elements with the flood-sediment data. The analyses are divided into those of streambed sediment from the South Fork (fig. 19A), soils and sedimentary deposits on the South Fork historical flood plain (fig. 19B), streambed sediment from the Coeur d'Alene River below Cataldo (fig. 20A), and soils and sedimentary deposits from the active Coeur d'Alene River flood plain (fig. 20B). Much higher metal contents are common in soils on the historical flood plain of the South Fork of the Coeur d'Alene River than on the active flood plain of the main stem of the Coeur d'Alene River below Cataldo, or in streambed sediment from either channel reach. Also noteworthy are the contrasting $\mathrm{Zn} / \mathrm{Pb}$ ratios between the flood-plain soils/sedimentary deposits and the streambed sediment. $\mathrm{Zn} / \mathrm{Pb}$ ratios for South Fork streambed sediment scatter on both sides of 1.0 (fig. 19A), average about 1.25 for Coeur d'Alene River streambed sediment below Cataldo (fig. 20A), and average much less than 1.0 for sedimentary deposits from either flood-plain segment (figs. 19B, 20B). The apparent cause of this variation in $\mathrm{Zn} / \mathrm{Pb}$ ratio is the higher solubility of $\mathrm{Zn}$ than of $\mathrm{Pb}$ in oxidized surface and ground waters of the drainage basin. Percolating soil water gradually leaches $\mathrm{Zn}$ from the oxidized surface soils, lowering the soil $\mathrm{Zn} / \mathrm{Pb}$ ratio as the soil weathers. Some fraction of dissolved $\mathrm{Zn}$ in surface water of the lower Coeur d'Alene River has been shown to sorb onto inorganic or organic surfaces between Cataldo and Harrison (Paulson, 2001). The influx of slightly acidic ground water with high dissolved $\mathrm{Zn}$ and low dissolved $\mathrm{O}$ contents into oxygenated waters of the river channel results in precipitation of fine $\mathrm{Fe}$ and $\mathrm{Mn}$ oxyhydroxides with a high content of sorbed $\mathrm{Zn}$ but low $\mathrm{Pb}$ content (Balistrieri and others, 2003). These processes result in $\mathrm{Zn} / \mathrm{Pb}$ ratios of 1.0 or greater in submerged-channel sediment.

The contrasts in $\mathrm{Zn} / \mathrm{Pb}$ ratio among some of the samples of flood sediment (fig. 15B) might be explainable by differences in sediment sources. The 1995-97 samples of flood sediment (except for the tributary samples) approximately separate (fig. 15B) into those with $\mathrm{Zn} / \mathrm{Pb}$ ratios less than 1.0 (all 1996 samples except those of lower Coeur d'Alene River streambank deposits) and those with $\mathrm{Zn} / \mathrm{Pb}$ ratios greater than 1.0 (all the samples of 1997 suspended sediment plus those of the lower Coeur d'Alene streambank deposits). By analogy with the potential flood-sediment source materials (figs. 19, 20), the lower $\mathrm{Zn} / \mathrm{Pb}$ ratios of the 1996 samples of suspended and marsh sediment are consistent with a greater component of eroding-flood-plain soils, whereas the higher $\mathrm{Zn} / \mathrm{Pb}$ ratios of the 1997 samples of suspended sediment suggest a larger component derived from streambed sediment.

Before we discuss how these differences in flood sediment source materials might be explained, we present some crude calculations of the potential contributions of fine sediment from streambed, the streambank, and flood-plain deposits. Mobilization of sandy streambed sediment releases the incorporated fine $(<0.063$-mm grain size) fraction (avg 30 weight percent in the lower Coeur d'Alene River; U.S. Environmental Protection Agency, 1998) into washload suspension throughout the water column. Mobilization of the upper $10 \mathrm{~cm}$ of streambed deposits over the 50-m average width of historical deposits in the Coeur d'Alene River below Cataldo yields about $1.5 \mathrm{~m}^{3}$ of fines per linear meter of channel. Erosion of streambanks, with the average streambank lateral-erosion rate of $6.4 \mathrm{~cm} / \mathrm{yr}$ on each streambank (derived from measurements at 34 sites over 4 years: S.E. Box and A.A. Bookstrom, unpub. data, 2000), an average thickness of $0.7 \mathrm{~m}$ of metal-enriched streambank soil/sedimentary deposit (Bookstrom and others, 2001), and an average fine (...0.063-mm grain size) fraction of 60 weight percent (data from the lower Coeur d'Alene River; U.S. Environmental Protection Agency, 1998) yields about $0.05 \mathrm{~m}^{3}$ of fines per linear meter of channel, or about 4 percent of the inferred yield of mobilized streambed deposits. Mobilization (during overbank flooding) of the upper $2 \mathrm{~cm}$ of the sandy, poorly vegetated natural levee (average width, $360 \mathrm{~m}$ : Bookstrom and others, 2001) of the Coeur d'Alene River below Cataldo (upland of Bookstrom and others, 1999, 2001), with an average of 60 weight percent fine $(<0.063-\mathrm{mm}$ grain size) fraction (U.S. Environmental Protection Agency, 1998) would yield $4.3 \mathrm{~m}^{3}$ of fines per linear meter of valley, nearly 100 times that calculated from eroding streambank deposits and 3 times that from resuspended streambed sediment. Although considerable uncertainty exists in the depth of mobilization of either the streambed sediment or the upland flood-plain surface, mobilization of a thin surficial layer over their broad areal extent clearly would volumetrically overwhelm the contribution of a much thicker but also much narrower slice of eroding streambank deposits.

The large February 1996 flood had a suspended washload about 100 times greater than that of the smaller May 1997 flood (fig. 10B). Because only minor overbank flooding occurred along the South Fork of the Coeur d'Alene River (figs. 1, 2) in the February 1996 flood, we infer that the primary sources of suspended sediment over that reach must have been from remobilized streambed sediment and from eroding streambank deposits. Given the high metal contents of the flood-plain deposits exposed in streambanks along the South Fork (fig. 19B) relative to those of the streambed sediment in the same reach (fig. 19A), only a small input of eroding-streambank deposits would be required to produce the low $\mathrm{Zn} / \mathrm{Pb}$ ratios of the 1996 samples of South Fork suspended sediment, even if it was derived predominately from remobilized streambed sediment. Along the Coeur d'Alene River below Cataldo in the February 1996 flood, extensive overbank 

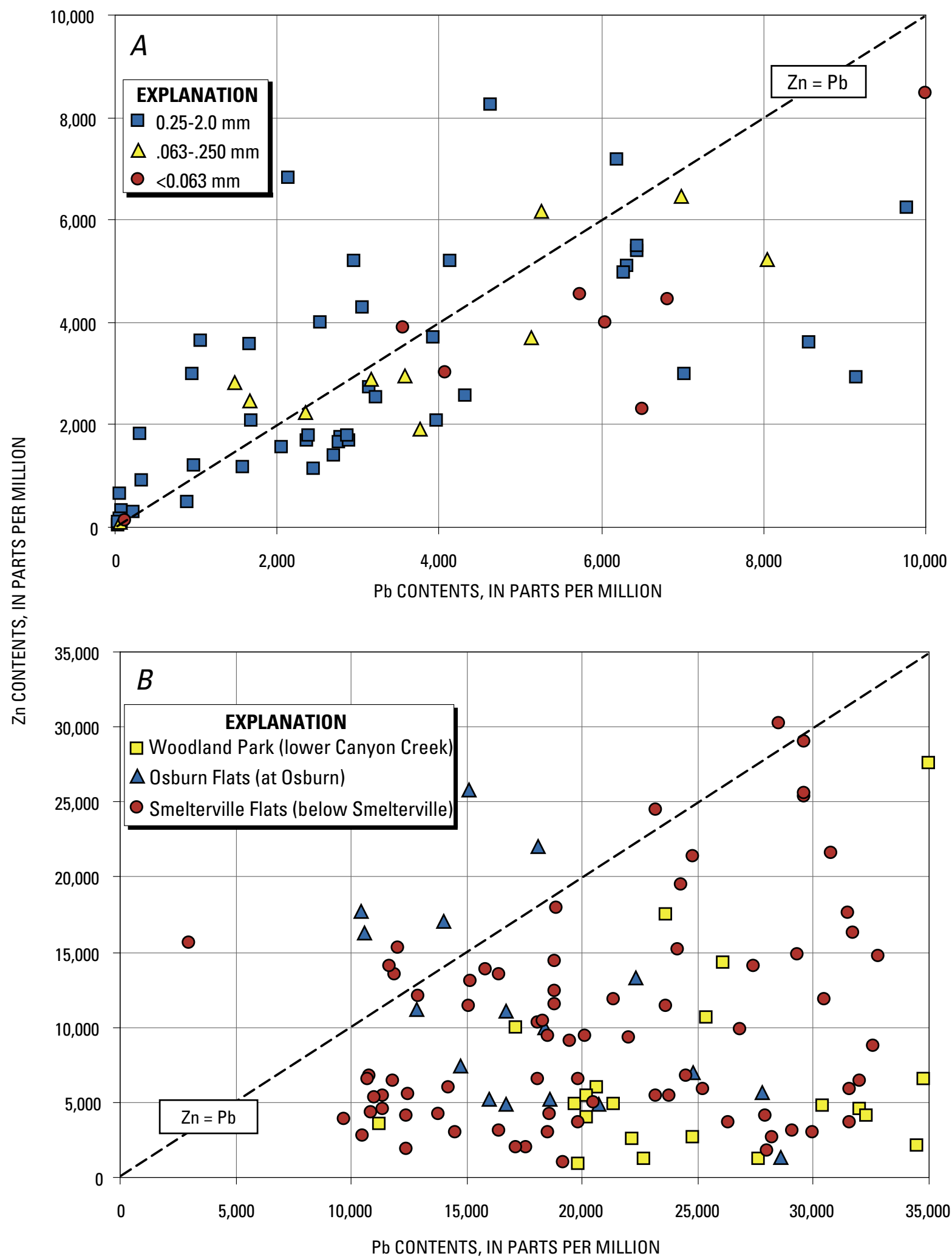

Figure 19. Zn versus $\mathrm{Pb}$ contents in potential flood-sediment source materials in and along the South Fork of the Coeur d'Alene River, northern Idaho (see fig. 1). A, Streambed sediment, analyzed by grain-size fraction. Data from Box and others (2001). B, Unfractionated historical flood-plain soils. Data from McCulley and others (1995), Golder Associates (1996), and Terragraphics Environmental Engineering, Inc. (1996). Dashed diagonal line indicating equal $\mathrm{Zn}$ and $\mathrm{Pb}$ contents is shown for reference. 


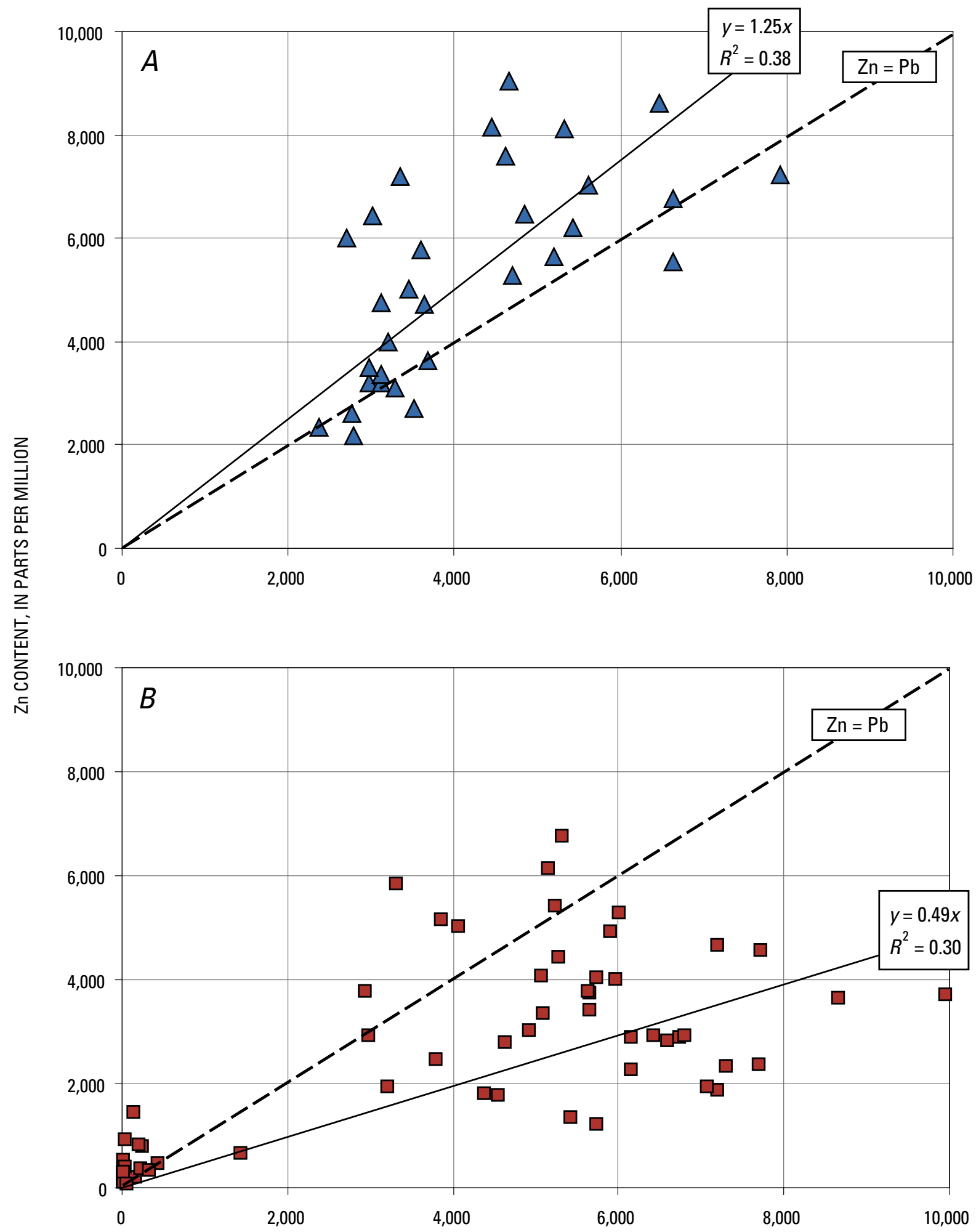

Pb CONTENT, IN PARTS PER MILLION

Figure 20. Zn versus $\mathrm{Pb}$ contents in potential flood-sediment source materials in and along main stem of the Coeur d'Alene River downstream from Cataldo, Idaho (fig. 1), showing linear-regression lines for all samples and coefficients of determination ( $R^{2}$, calculated by least-squares method). Data from Box and others (2001). $A$, Uppermost 1 $\mathrm{m}$ of streambed sediment. $B$, Historical streambank deposits. Dashed diagonal line indicating equal concentrations of $\mathrm{Zn}$ and $\mathrm{Pb}$ shown for reference in each diagram. $\mathrm{Zn}$ content is generally greater than $\mathrm{Pb}$ content in streambed sediment but is generally less than $\mathrm{Pb}$ content in weathered streambank deposits. 
flooding did occur, and so both eroding streambank deposits and resuspension of the fine fraction of surficial flood-plain soils are potential sources of the lower- $\mathrm{Zn} / \mathrm{Pb}$-ratio component. Because of the volumetric considerations discussed above, resuspension of the fine fraction of upland exposures of Coeur d'Alene River flood-plain soils probably was the predominant source of the low-Zn/Pb-ratio Coeur d'Alene River suspended sediment sampled in 1996 (fig. 21A).

The consistently high $\mathrm{Zn} / \mathrm{Pb}$ ratio of suspended sediment in the 1997 floods contrasts with that in the February 1996 flood (fig. 15B). We suggest that the 1997 samples of suspended sediment on the South Fork and main stem of the Coeur d'Alene River were primarily derived by resuspension of the fine fraction of the streambed sediment, which has a $\mathrm{Zn} / \mathrm{Pb}$ ratio greater than 1.0. The lower discharge in the 1997 floods (that is, 20,000 versus 70,000 $\mathrm{ft}^{3} / \mathrm{s}$ on the Coeur d'Alene River at Cataldo) produced lower river-surface elevations on the South Fork (below most cutbanks of metal-enriched flood-plain soil) and slower, less erosive currents on the flood plain of the lower Coeur d'Alene River valley than in the February 1996 flood, reducing the relative contribution of flood-plain soils to the suspended sediment. This lesser discharge of the 1997 floods (30 percent that of the February 1996 flood) and its smaller suspended sediment load ( 1 percent that of the February 1996 flood) resulted in the predominance of streambed-derived fines over streambankor flood-plain-soil-derived fines in the suspended-sediment load (fig. 21B). Because the recurrence interval of floods like those of 1997 (3-4 years at Cataldo) is much shorter than that of the February 1996 flood (approx 100 years), we infer that streambed-derived fines are the dominant source of the suspended sediment load in most high-flow events.

Suspended sediment in the Spokane River at the outlet of Coeur d'Alene Lake in May 1997, occurring at low concentrations even at the highest flows, was dominated by metalenriched fines that had traversed the lake after input from the mouth of the Coeur d'Alene River. This interpretation is strongly supported by the similarity of their Fe and Mn contents and of their $\mathrm{Pb} / \mathrm{Fe}$ and $\mathrm{Pb} / \mathrm{Mn}$ ratios to those of Coeur d'Alene River suspended sediment from all sampled floods, and by the similarity of their $\mathrm{Zn} / \mathrm{Fe}, \mathrm{Zn} / \mathrm{Mn}$, and $\mathrm{Zn} / \mathrm{Pb}$ ratios to those of
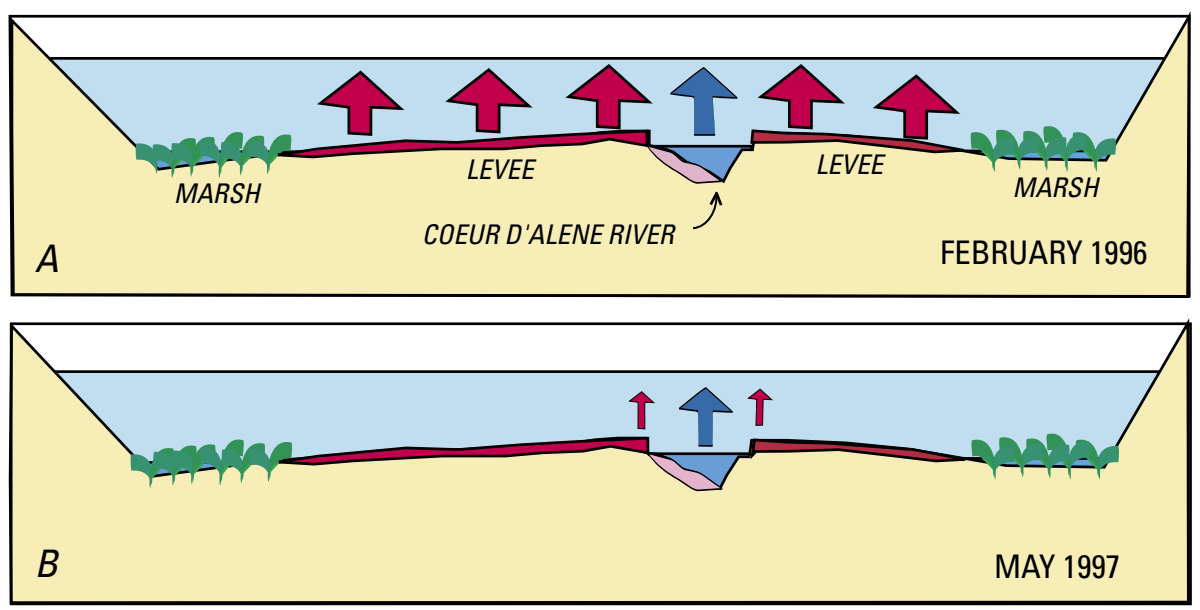

Figure 21. Schematic cross sections of the lower Coeur d'Alene River valley, northern Idaho (fig. 1), during overbank flooding in February $1996(A)$ and May $1997(B)$. Although overbank floods reached similar floodwater elevations in the lake-backwater-influenced lower Coeur d'Alene valley during the two high-flow events, geochemistry of fine suspended sediment in each flood was distinctive because of different balance of flood-sediment sources. Dark blue, water elevation in river channel during low-flow conditions; light blue, floodwater elevation; red, metal-enriched flood-plain-levee soil; green, backlevee marsh; yellow, premining valley deposits and bedrock. Short-duration high discharge during February 1996 flood (50-100-year recurrence interval) generated high flow velocities over thinly vegetated natural flood-plain levees, mobilizing fine metal-enriched material with low $\mathrm{Zn} / \mathrm{Pb}$ ratio from weathered flood-plain surface (large red arrows, fig. 21A), which dominated suspended-sediment budget over bedload-derived fine material from channel (large blue arrow). In contrast, long-duration, moderate discharge during May 1997 flood (3-4-year recurrence interval) raised elevation of Coeur d'Alene Lake and backflooded the lower Coeur d'Alene River valley, with floodwater elevations slightly higher than in February 1996. Lower flow velocities over flood-plain levees in 1997 flood did not significantly mobilize surface materials, such that suspended-sediment budget was dominated by fine material winnowed out of remobilized streambed sediment (large blue arrow, fig. 21B), with lesser contributions from erosion of weathered streambank deposits and flood-plain soils (small red arrows). 
Coeur d'Alene River suspended sediment from the same highflow event. However, the increases in suspended-sediment concentration and metal loads farther downstream in the Spokane River indicate addition of metal-rich suspended sediment mobilized from the streambed sediment. The distinctly lower $\mathrm{Ag} / \mathrm{Pb}$ ratio in 1997 suspended-sediment samples from the Spokane River (figs. $18 B, 18 C$ ) apparently reflect a similar ratio in Spokane River streambed sediment (Grosbois and others, 2001); the cause of this and, possibly, other contrasting ratios (for example, $\mathrm{Sb} / \mathrm{Pb}$ ) in the source is uncertain. The $\mathrm{Ag} / \mathrm{Pb}$ and $\mathrm{Sb} / \mathrm{Pb}$ ratios of Coeur d'Alene Lake bottom sediment do not show a decreasing trend northward in the lake or a correlation with grain size at any sampling site (Horowitz and others, 1993), as would be expected if the contrasting ratios were produced during transit through Coeur d'Alene Lake.

Samples of marsh sediment deposited in the Coeur d'Alene River valley during the 1996 flood have metal ratios similar to those of samples of suspended sediment collected from the adjacent Coeur d'Alene River in the same flood and were presumably deposited from the fallout of suspended sediment during the month-long inundation of the flood plain. However, metal contents of most marsh-sediment samples are somewhat lower than those of the nearest peak-flow suspended-sediment samples. The cause of this apparent decrease in metal contents is uncertain. We suggest two possible causes: (1) suspended sediment similar in metal contents to peak-flow suspended sediment was deposited in the marshes during peak flow, but deposition of lower-metal-content material followed during the longer period of flood-plain inundation, leading to lower average metal contents of the flood deposits; or (2) the high specific gravity of $\mathrm{Fe}$ and $\mathrm{Mn}$ compounds bearing the other heavy metals caused them to preferentially settle out as currents waned with distance from the channel.

The most striking downstream trend in samples of streambank deposits from both the 1995 and 1996 floods is the sharp increase in metal contents below the gradient break in the Coeur d'Alene River below Cataldo (fig. 13). This downstream change in the elemental composition of streambank deposits correlates with the similar change in elemental composition of sandy streambed sediment across that gradient break, because the streambank deposits represent entrained streambed sediment that was dropped on the natural levee as water spilled out of the channel (fig. 14). Above the gradient break, streambed sediment consists of coarse cobbly bars, capped locally by ephemeral sandbars; below the gradient break, cobbles are absent, and surficial streambed sediment consists of several meters of metal-enriched sand and silt accumulated since the onset of mining in the drainage basin (U.S. Environmental Protection Agency, 1998; Box and others, 2001). Reduction in the input of metal-rich sediment to the main stem from the Coeur d'Alene River by the South Fork after the cessation of tailings releases in 1968 has resulted in more effective dilution of the fine fraction of streambed sediment in the cobbly channel below the confluence by the metalpoor component from the North Fork. Higher metal contents in the sandy surficial streambed sediment below the gradient break are maintained by remobilization of the underlying, historical metal-rich streambed deposits, resulting in the contrast in metal content above and below the gradient break.

\section{Conclusions}

1. Suspended-sediment concentrations were 10 to 20 times greater, and peak flows 4 to 5 times higher, during the 100-year flood of 1996 than during the 2- to 5-year floods of 1997, resulting in suspended-sediment loads as much as 100 times higher in 1996. The daily $\mathrm{Pb}$ and $\mathrm{Zn}$ loads in suspended sediment (in weight of metals transported in suspended sediment past a given point per unit time) were also typically about 100 times greater during the 1996 flood.

2. Contents of nine mining-related elements $(\mathrm{Pb}, \mathrm{Zn}, \mathrm{Fe}$, $\mathrm{Mn}, \mathrm{Ag}, \mathrm{Cd}, \mathrm{Cu}, \mathrm{Sb}, \mathrm{As}$ ) in suspended sediment typically increase downstream along the South Fork of the Coeur d'Alene River through the Coeur d'Alene Mining District, decrease below the confluence of the North and South Forks, and increase again downstream below the gradient break at Cataldo. Metal contents in suspended sediment of the Spokane River below Coeur d'Alene Lake were similar to those of the lower Coeur d'Alene River above the lake during the 1997 spring runoff.

3. The ratios of most mining-related elements $(\mathrm{Pb}, \mathrm{Zn}, \mathrm{Ag}$, $\mathrm{Sb}, \mathrm{Cd})$ to $\mathrm{Fe}$ and $\mathrm{Mn}$ are similar within each river reach (tributaries to the South Fork of the Coeur d'Alene River, the South Fork of the Coeur d'Alene River, the main stem of the Coeur d'Alene River, and the Spokane River). SEM observations indicate that these elements occur primarily in fine aggregates and grain coatings of amorphous $\mathrm{Fe}$ and $\mathrm{Mn}$ oxyhydroxide compounds and that the other mining-related elements are adsorbed onto the Fe and Mn compounds. Changes in the ratios of most mining-related elements to $\mathrm{Fe}$ or Mn between river reaches could be due to downstream changes in $\mathrm{Fe}$ and $\mathrm{Mn}$ oxyhydroxide compounds because of aging, or to subtle physicochemical source changes in river water or in pore water in the suspended sediment source areas (streambed or streambanks). Much of the $\mathrm{Zn}$ in Spokane River suspended sediment is not associated with Fe or Mn but is inferred to be associated with organic matter generated in the Coeur d'Alene River (Paulson, 2001), in Coeur d'Alene Lake (Kuwabara and others, 2000) and in the Spokane River (Box and Wallis, 2002).

4. The contrasting geochemistry between suspended-sediment samples from the 1996 and 1997 floods indicates that the predominant suspended-sediment sources differed between the 100-year flood of 1996 and the 2-5-year floods of 1997. The 1996 suspended sediment is most geochemically similar to flood-plain soil over the same reach, whereas the 1997 suspended sediment is most similar to streambed sediment over the same reach. Volumetric considerations suggest that the larger 
suspended-sediment loads in the February 1996 flood (100 times larger than those in the May 1997 flood) were most likely released to suspension when overbank traction currents remobilized flood-plain soils on the broad, poorly vegetated natural levees (upland of Bookstrom and others, 2001) of the lower Coeur d'Alene River. This remobilization of flood-plain soils apparently was less significant in the smaller floods of 1997, and so the smaller suspended-sediment load was dominated by fine material released during the mobilization of streambed sediment. Similar material was released from mobilized streambed sediment in both the 1996 and 1997 floods, but its geochemical signature was dwarfed in the 1996 flood by the much larger contribution from remobilized flood-plain soils.

5. Suspended sediment in the Spokane River at the immediate outlet of Coeur d'Alene Lake consists of suspended sediment derived from the lower Coeur d'Alene River that transited the lake. Farther downstream, however, the suspended-sediment and metal loads gradually increase through addition of fine sediment mobilized from previously deposited sediment in the riverbed. After 20 river mi (that is, in Washington) this sediment component derived from the riverbed accounts for 70 percent of the $\mathrm{Pb}$ load and more than 80 percent of the $\mathrm{Zn}$ load carried as suspended sediment.

6. Samples of overbank deposits in the backlevee marshes collected after the 100-year flood of 1996 have similar metal ratios to those of peak-flow suspended sediment over the same river reach, but with generally lower metal contents. Flood deposits on the immediate streambank or natural levee of the river are typically composed of sandy material mobilized from sandy streambed sediment in the adjacent river reach, which have similar metal contents and ratios.

\section{Acknowledgments}

We are grateful to Mike Beckwith (formerly of the U.S. Geological Survey) for his help in gaining access to critical sampling sites during the February 1996 flood. We appreciate the help of Yvonne Isaak and Kevin Myers in processing our samples, and of John Wallis in drafting the figures. We thank Bob Hooper for sharing the results of his SEM analyses of our samples. We also thank Jim Rytuba and Laurie Balistrieri for their helpful reviews of the manuscript.

\section{References Cited}

Abraham, Joju, 1994, Impact of mining on the trace element geochemistry and lead isotopic composition of sediments in Coeur d'Alene River, Idaho: Cheney, Eastern Washington University, M.S. thesis, 149 p.
Balistrieri, L.S., Box, S.E., and Tonkin, J.W., 2003, Modeling precipitation and sorption of elements during mixing of river water and porewater in the Coeur d'Alene River basin: Environmental Science and Technology, v. 37, p. 4694-4701.

Beckwith, M.A., Berenbrock, Charles, and Backsen, R.L., 1996, Magnitude of floods in northern Idaho, February 1996: U.S. Geological Survey Fact Sheet 222-96.

Bookstrom, A.A., Box, S.E., Campbell, J.K., Foster, K.I., and Jackson, B.L., 2001, Lead-rich sediment, Coeur d'Alene River valley, Idaho; area, volume, tonnage and lead content: U.S. Geological Survey Open-File Report 01-140, 77 p.

Bookstrom, A.A., Box, S.E., Jackson, B.L., Brandt, T.R., Derkey, P.D., and Munts, S.R., 1999, Digital map of surficial geology and wetlands, Coeur d'Alene River valley, Idaho: U.S. Geological Survey Open-File Report 99-548, 121 p., 11 sheets, scales 1:24,000, 1:60,000.

Box, S.E., Bookstrom, A.A., Ikramuddin, Mohammed, and Lindsay, James, 2001, Geochemical analyses of soils and sediments, Coeur d'Alene drainage basin, Idaho; sampling, analytical methods and results: U.S. Geological Survey Open-File Report 01-139, 230 p.

Box, S.E., and Wallis, J.L., 2002, Surficial geology along the Spokane River, Washington, and its relationship to the metal contents of sediments: U.S. Geological Survey Open-File Report 02-126, 54 p., scale 1:24,000.

Edwards, T.K., and Glysson, G.D., 1999, Field methods for measurement of fluvial sediment: U.S. Geological Survey Techniques of Water Resources Investigations Report TWI 03-C2, $89 \mathrm{p}$.

Ellis, M., 1940, Pollution of the Coeur d'Alene River and adjacent waters by mine wastes: U.S. Bureau of Fisheries Special Scientific Report 1, 61 p. [available from U.S. Fish and Wildlife Service, Washington, D.C.].

Fousek, R.S., 1996, Trace element distributions in the sediments of the floodplain and river banks of the South Fork and Coeur d'Alene Rivers, Shoshone and Kootenai Counties, Idaho: Auburn, Ala., Auburn University, M.S. thesis, 310 p.

Fryklund, V.C., Jr., 1964, Ore deposits of the Coeur d'Alene district, Shoshone County, Idaho: U.S. Geological Survey Professional Paper 445, $139 \mathrm{p}$.

Golder Associates, 1996, Test pit logs, soil/sediment analytical results, and contaminated sediment volume estimates, Osburn reach of South Fork of Coeur d'Alene River: Kellogg, Idaho, consultant report to Idaho Silver Valley Natural Resources Trust Fund, 68 p.

Grosbois, C.A., Horowitz, A.J., Smith, J.J., and Elrick, K.A., 2001, The effect of mining and related activities on the sediment-trace element geochemistry of Lake Coeur d'Alene, Idaho, U.S.A. Part III, Downstream effects; the Spokane River basin: Hydrological Processes, v. 15, no. 5, p. $855-875$. 
Hooper, R.L., and Mahoney, J.B., 2000, Constraining contaminant transport: lead and zinc speciation in fluvial subenvironments, lower Coeur d'Alene River valley, Idaho [abs.]: Geological Society of America Abstracts with Programs, v. 32, no. 7, p. 125 .

Horowitz, A.J., Elrick, K.A., and Cook, R.B., 1993, Effect of mining and related activities on the sediment trace element geochemistry of Lake Coeur d'Alene, Idaho, USA. Part I, Surface sediments; Hydrological Processes, v. 7, p. 403-423.

Horowitz, A.J., Elrick, K.A., Robbins, J.A., and Cook, R.B., 1995, Effect of mining and related activities on the sediment trace element geochemistry of Lake Coeur d'Alene, Idaho, USA. Part II, Subsurface sediments: Hydrological Processes, v. 9., p. 35-54.

Horowitz, A.J., Rinella, F.A., Lamothe, Paul, Miller, T.L., Edwards, T.K., Roche, R.L., and Rickert, D.A., 1990, Variations in suspended sediment and associated trace element concentrations in selected riverine cross sections: Environmental Science and Technology, v. 24, p. 1313-1320.

Kjelstrom, L.C., 1996, Gaging stations with 10 or more years of record, v. 1 of Statistical summaries of streamflow data for selected gaging stations in Idaho and adjacent States through September 1990: U.S. Geological Survey WaterResources Investigations Report 94-4069, 533 p.

Kuwabara, J.S., Berelson, W.M., Balistrieri, L.S., Woods, P.F., Topping, B.R., Steding, D.J., and Krabbenhoft, D.P., 2000, Benthic flux of metals and nutrients into the water column of Lake Coeur d'Alene, Idaho, report of an August 1999 pilot study: U.S. Geological Survey Water-Resources Investigations Report 00-4132, 74 p.

Long, K.R., 1998, Production and disposal of mill tailings in the Coeur d'Alene mining region, Shoshone County, Idaho; preliminary estimates: U.S. Geological Survey Open-File Report 98-595, 14 p.

Long, K.R., DeYoung, J.H., Jr., and Ludington, S.D., 1998, Database of significant deposits of gold, silver, copper, lead, and zinc; part A, Database description and analysis: U.S. Geological Survey Open-File Report 98-206-A, 33 p.

McCulley, Frick \& Gilman, Inc., 1995, Engineering evaluation/cost analysis for the Canyon Creek site: Osburn, Idaho, prepared for Idaho Silver Valley Natural Resource Trustees, $34 \mathrm{p}$.
Paulson, A.J., 1996, Fate of metals in surface waters of the Coeur d'Alene basin, Idaho: U.S. Bureau of Mines Report of Investigations 9620, 75 p.

Paulson, A.J., 2001, Biogeochemical removal of $\mathrm{Zn}$ and $\mathrm{Cd}$ in the Coeur d'Alene River (Idaho, USA), downstream of a mining district: Science of the Total Environment, v. 278, p. $31-44$.

Paulson, A.J., Balderrama, Robert, and Zahl, Eric, 1996, Treatment of fluvially deposited streamside mine wastematerial from Canyon Creek, Idaho: U.S. Bureau of Mines Report of Investigations 9633, 58 p.

Terragraphics Environmental Engineering, Inc., 1996, Smelterville Flats soil data report: Boise, Idaho, unpublished report to Idaho Department of Health and Welfare, 31 p.

U.S. Environmental Protection Agency, 1998, Bunker Hill Facility basin-wide RI/FS data report-sediment contamination in the lower Coeur d'Alene River basin (LCDARB); geophysical and sediment coring investigations in the river channel, lateral lakes and floodplains: Seattle, consultant report prepared by URS Greiner, Inc., and CH2M Hill, 2 v.

U.S. Geological Survey, 1984, National handbook of recommended methods for water-data acquisition (revised ed.): Reston, Va., 692 p.

U.S. Geological Survey, 1996, Upper Columbia River Basin and Snake River Basin below King Hill, v. 2 of Water resources data, Idaho_-water year 1995: U.S. Geological Survey Water-Data Report ID-95-2, 357 p.

U.S. Geological Survey, 1997, Upper Columbia River Basin and Snake River Basin below King Hill, v. 2 of Water resources data, Idaho_-water year 1996: U.S. Geological Survey Water-Data Report ID-96-2, 377 p.

U.S. Geological Survey, 1998, Upper Columbia River Basin and Snake River Basin below King Hill, v. 2 of Water resources data, Idaho_-water year 1997: U.S. Geological Survey Water-Data Report ID-97-2, 357 p.

Woods, P.F., and Beckwith, M.A., 1997, Nutrient and trace element enrichment of Coeur d'Alene Lake, Idaho: U.S. Geological Survey Water-Supply Paper 2485, 93 p.

Woods, P.F., and Berenbrock, Charles, 1994, Bathymetric map of Coeur d'Alene Lake, Idaho: U.S. Geological Survey Water-Resources Investigations Report 94-4119, scale 1:48,000. 

Tables 1-3 
Table 1. Analytical data for samples of suspended sediment collected from the Coeur d'Alene-Spokane River system, northern Idaho and eastern Washington, during high-water events in 1996 and 1997.

[See figures 1 and 2 for locations. Samples grouped by sampling date and listed from upstream to downstream. Samples from tributaries near their mouths are listed separately for each sampling date. n.a., not analyzed]

\begin{tabular}{|c|c|c|c|c|c|c|c|c|}
\hline Sample & Location & $\begin{array}{l}\text { Sampling } \\
\text { date }\end{array}$ & $\begin{array}{c}\text { Latitude } \\
\mathbf{N} .\end{array}$ & $\begin{array}{c}\text { Longitude } \\
\text { W. }\end{array}$ & $\begin{array}{c}\text { River } \\
\text { miles } \\
\text { below } \\
\text { Mullan, } \\
\text { Idaho }\end{array}$ & $\begin{array}{c}\text { Suspended- } \\
\text { sediment } \\
\text { concentration } \\
\text { (mg/L) }\end{array}$ & $\underset{(\mathbf{p p m})}{\mathbf{A g}}$ & $\begin{array}{l}\text { Al } \\
\text { (wt } \\
\text { pct) }\end{array}$ \\
\hline
\end{tabular}

Coeur d'Alene River, February 9-10, 1996

\begin{tabular}{|c|c|c|c|c|c|c|c|c|}
\hline 1 & South Fork at Twomile Creek -------- & $02 / 09 / 96$ & $47^{\circ} 28^{\prime} 32^{\prime \prime}$ & $115^{\circ} 54^{\prime} 51^{\prime \prime}$ & 12.5 & 616 & 12.2 & 7.45 \\
\hline 2 & South Fork at the Smelterville bridge -- & $02 / 09 / 96$ & $47^{\circ} 28^{\prime} 29^{\prime \prime}$ & $115^{\circ} 55^{\prime} 20^{\prime \prime}$ & 22.4 & 1,388 & 19.8 & 6.75 \\
\hline 3 & 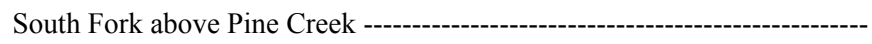 & $02 / 10 / 96$ & $47^{\circ} 30^{\prime} 36^{\prime \prime}$ & $115^{\circ} 59^{\prime} 33^{\prime \prime}$ & 25.3 & 104 & 13.4 & 8.02 \\
\hline 4 & Coeur d'Alene River at Kingston -- & $02 / 09 / 96$ & $47^{\circ} 32^{\prime} 55^{\prime \prime}$ & $116^{\circ} 10^{\prime} 27^{\prime \prime}$ & 27.8 & 534 & 6.5 & 7.70 \\
\hline 5 & Coeur d'Alene River at the Idaho Highway 2 bridge at Cataldo---------- & $02 / 09 / 96$ & $47^{\circ} 32^{\prime} 55^{\prime \prime}$ & $116^{\circ} 13^{\prime} 17^{\prime \prime}$ & 32.0 & 490 & 3.4 & 8.70 \\
\hline 6 & Coeur d'Alene River above Dudley --.-- & $02 / 09 / 96$ & $47^{\circ} 33^{\prime} 12^{\prime \prime}$ & $116^{\circ} 16^{\prime} 09^{\prime \prime}$ & 37.3 & 52 & 7.6 & 10.45 \\
\hline 7 & Coeur d'Alene River below Rose Lake -- & $02 / 09 / 96$ & $47^{\circ} 32^{\prime} 53^{\prime \prime}$ & $116^{\circ} 20^{\prime} 04^{\prime \prime}$ & 43.4 & 426 & 5.3 & 9.62 \\
\hline 8 & Coeur d'Alene River at Anderson Lake inlet -- & $02 / 10 / 96$ & $47^{\circ} 32^{\prime} 39^{\prime \prime}$ & $116^{\circ} 24^{\prime} 43^{\prime \prime}$ & 61.4 & 138 & 16.5 & 6.14 \\
\hline
\end{tabular}

Tributaries to the Coeur d'Alene River, February 9-10, 1996

\begin{tabular}{|c|c|c|c|c|c|c|c|c|}
\hline 9 & Canyon Creek at mouth -------. & $02 / 09 / 96$ & $47^{\circ} 32^{\prime} 04^{\prime \prime}$ & $116^{\circ} 30^{\prime} 54^{\prime \prime}$ & 7.0 & 14 & 45.1 & 6.11 \\
\hline 10 & Ninemile Creek at mouth ----------------- & $02 / 09 / 96$ & $47^{\circ} 27^{\prime} 56^{\prime \prime}$ & $116^{\circ} 45^{\prime} 47^{\prime \prime}$ & 7.5 & 699 & 29.3 & 7.87 \\
\hline \multicolumn{9}{|c|}{ Coeur d'Alene River, January 2, 1997} \\
\hline 11 & South Fork at Enaville -------- & $01 / 02 / 97$ & $47^{\circ} 31^{\prime} 47^{\prime \prime}$ & $116^{\circ} 02^{\prime} 05^{\prime \prime}$ & 26.7 & 104 & 10.8 & 7.53 \\
\hline \multicolumn{9}{|c|}{ Tributaries to the Coeur d'Alene River, January 2, 1997} \\
\hline 12 & Canyon Creek at mouth -------------.. & $01 / 02 / 97$ & $47^{\circ} 33^{\prime} 34^{\prime \prime}$ & $116^{\circ} 15^{\prime} 03^{\prime \prime}$ & 7.0 & 7 & 37.3 & 6.10 \\
\hline 13 & 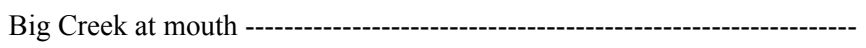 & $01 / 02 / 97$ & $47^{\circ} 28^{\prime} 22^{\prime \prime}$ & $115^{\circ} 54^{\prime} 50^{\prime \prime}$ & 15.8 & 25 & 9.1 & 6.93 \\
\hline 14 & Government Gulch at mouth ------------------------------------------ & $01 / 02 / 97$ & $47^{\circ} 32^{\prime} 44^{\prime \prime}$ & $116^{\circ} 09^{\prime} 59^{\prime \prime}$ & 22.2 & 1,471 & 13.9 & 8.26 \\
\hline 15 & Page Creek above tailings pond -- & $01 / 02 / 97$ & $47^{\circ} 32^{\prime} 24^{\prime \prime}$ & $116^{\circ} 12^{\prime} 09^{\prime \prime}$ & 24.3 & 60 & 6.5 & 7.75 \\
\hline 16 & 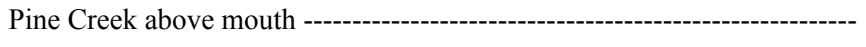 & $01 / 02 / 97$ & $47^{\circ} 32^{\prime} 51^{\prime \prime}$ & $116^{\circ} 13^{\prime} 31^{\prime \prime}$ & 25.3 & 119 & 1.0 & 8.03 \\
\hline
\end{tabular}


Table 1. Analytical data for samples of suspended sediment collected from the Coeur d'Alene-Spokane River system, northern Idaho and eastern Washington, during high-water events in 1996 and 1997.-Continued

\begin{tabular}{|c|c|c|c|c|c|c|c|c|}
\hline Sample & Location & $\begin{array}{l}\text { Sampling } \\
\text { date }\end{array}$ & $\begin{array}{c}\text { Latitude } \\
\quad \mathbf{N} .\end{array}$ & $\begin{array}{l}\text { Longitude } \\
\text { W. }\end{array}$ & $\begin{array}{c}\text { River } \\
\text { miles } \\
\text { below } \\
\text { Mullan, } \\
\text { Idaho }\end{array}$ & $\begin{array}{c}\text { Suspended- } \\
\text { sediment } \\
\text { concentration } \\
\text { (mg/L) }\end{array}$ & $\underset{(p p m)}{\mathbf{A g}}$ & $\begin{array}{l}\text { Al } \\
\text { (wt } \\
\text { pct) }\end{array}$ \\
\hline \multicolumn{9}{|c|}{ Spokane River, May 2, 1997} \\
\hline 17 & Spokane River at the Stateline bridge ----- & 05/02/97 & $47^{\circ} 41^{\prime} 55^{\prime \prime}$ & $117^{\circ} 02^{\prime} 36^{\prime \prime}$ & 98.3 & 3 & 2.0 & 8.01 \\
\hline 18 & Spokane River at the Centennial Trail bridge -- & 05/02/97 & $47^{\circ} 41^{\prime} 37^{\prime \prime}$ & $117^{\circ} 14^{\prime} 55^{\prime \prime}$ & 110.2 & 4 & 1.0 & 6.26 \\
\hline 19 & Spokane River at the Gonzaga University bridge ------- & 05/02/97 & $47^{\circ} 39^{\prime} 49^{\prime \prime}$ & $117^{\circ} 24^{\prime} 08^{\prime \prime}$ & 119.0 & 5 & 10.1 & 8.36 \\
\hline 20 & Spokane River at the 7-Mile bridge ------------------------------ & $05 / 02 / 97$ & $47^{\circ} 44^{\prime} 28^{\prime \prime}$ & $117^{\circ} 31^{\prime} 07^{\prime \prime}$ & 132.4 & 16 & 1.0 & 8.12 \\
\hline \multicolumn{9}{|c|}{ Coeur d'Alene-Spokane Rivers, May 19-20, 1997} \\
\hline 21 & South Fork at Larsen ----------------- & 05/20/97 & $47^{\circ} 28^{\prime} 01^{\prime \prime}$ & $115^{\circ} 43^{\prime} 59^{\prime \prime}$ & -3.2 & 1.4 & 0.9 & 7.16 \\
\hline 22 & 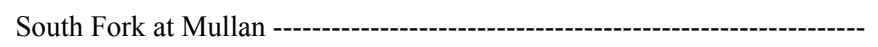 & 05/20/97 & $47^{\circ} 28^{\prime} 12^{\prime \prime}$ & $115^{\circ} 47^{\prime} 34^{\prime \prime}$ & 0.0 & 23 & 2.5 & 6.74 \\
\hline 23 & South Fork below the Morning Mine -- & 05/20/97 & $47^{\circ} 27^{\prime} 58^{\prime \prime}$ & $115^{\circ} 48^{\prime} 48^{\prime \prime}$ & 1.3 & 32 & 3.3 & 6.53 \\
\hline 24 & South Fork above Canyon Creek -- & 05/20/97 & $47^{\circ} 28^{\prime} 21^{\prime \prime}$ & $115^{\circ} 54^{\prime} 40^{\prime \prime}$ & 6.9 & 102 & 2.6 & 6.14 \\
\hline 25 & South Fork at west end of Wallace - & 05/20/97 & $47^{\circ} 28^{\prime} 37^{\prime \prime}$ & $115^{\circ} 55^{\prime} 57^{\prime \prime}$ & 8.0 & 92 & 2.8 & 5.88 \\
\hline 26 & South Fork at Twomile Creek & 05/20/97 & $47^{\circ} 30^{\prime} 36^{\prime \prime}$ & $115^{\circ} 59^{\prime} 33^{\prime \prime}$ & 12.5 & 11 & 4.3 & 7.39 \\
\hline 27 & South Fork at the Evolution bridge - - & 05/20/97 & $47^{\circ} 31^{\prime} 00^{\prime \prime}$ & $116^{\circ} 01^{\prime} 56^{\prime \prime}$ & 14.3 & 58 & 4.3 & 5.60 \\
\hline 28 & South Fork at Enaville --- & 05/20/97 & $47^{\circ} 33^{\prime} 34^{\prime \prime}$ & $116^{\circ} 15^{\prime} 03^{\prime \prime}$ & 26.7 & 83 & 6.8 & 6.95 \\
\hline 29 & Coeur d'Alene River at the Idaho Highway 2 bridge at Cataldo--------- & 05/20/97 & $47^{\circ} 32^{\prime} 52^{\prime \prime}$ & $116^{\circ} 20^{\prime} 02^{\prime \prime}$ & 32.0 & 20 & 5.2 & 7.77 \\
\hline 30 & Coeur d'Alene River at the Idaho Highway 3 bridge --- & 05/20/97 & $47^{\circ} 31^{\prime} 25^{\prime \prime}$ & $116^{\circ} 30^{\prime} 49^{\prime \prime}$ & 44.2 & 20 & 17.1 & 5.28 \\
\hline 31 & Spokane River at the Idaho Highway 95 bridge ----------- & 05/20/97 & $47^{\circ} 41^{\prime} 11^{\prime \prime}$ & $116^{\circ} 47^{\prime} 54^{\prime \prime}$ & 83.6 & 2 & 1.7 & 8.20 \\
\hline 32 & 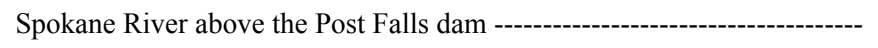 & 05/19/97 & $47^{\circ} 42^{\prime} 33^{\prime \prime}$ & $116^{\circ} 57^{\prime} 06^{\prime \prime}$ & 92.3 & 3 & 1.7 & 7.19 \\
\hline 33 & Spokane River at the Stateline footbridge --- & 05/19/97 & $47^{\circ} 41^{\prime} 45^{\prime \prime}$ & $117^{\circ} 02^{\prime} 18^{\prime \prime}$ & 98.0 & 4 & 2.5 & 7.39 \\
\hline 34 & 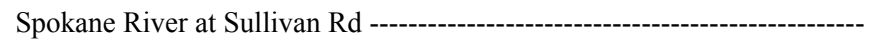 & 05/19/97 & $47^{\circ} 40^{\prime} 22^{\prime \prime}$ & $117^{\circ} 11^{\prime} 45^{\prime \prime}$ & 106.7 & 9 & 1.2 & 8.35 \\
\hline 35 & Spokane River at the Gonzaga University bridge ---1- & $05 / 19 / 97$ & $47^{\circ} 39^{\prime} 49^{\prime \prime}$ & $117^{\circ} 24^{\prime} 08^{\prime \prime}$ & 119.0 & 5 & 2.7 & 7.25 \\
\hline
\end{tabular}

Tributaries to the Coeur d'Alene River, May 20, 1997

\begin{tabular}{|c|c|c|c|c|c|c|c|c|}
\hline 36 & Mill Creek above Mullan -----------------. & $05 / 20 / 97$ & $47^{\circ} 28^{\prime} 19^{\prime \prime}$ & $115^{\circ} 48^{\prime} 01^{\prime \prime}$ & 0.2 & 5 & 10.0 & 4.31 \\
\hline 37 & 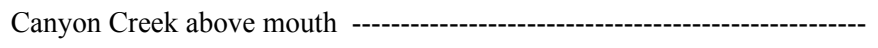 & $05 / 20 / 97$ & $47^{\circ} 28^{\prime} 32^{\prime \prime}$ & $115^{\circ} 54^{\prime} 51^{\prime \prime}$ & 7.0 & 7 & 29.3 & 5.14 \\
\hline 38 & 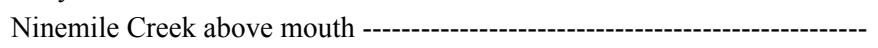 & 05/20/97 & $47^{\circ} 28^{\prime} 37^{\prime \prime}$ & $115^{\circ} 55^{\prime} 11^{\prime \prime}$ & 7.5 & 11 & 18.8 & 6.88 \\
\hline 39 & Big Creek at mouth -- & $05 / 20 / 97$ & $47^{\circ} 31^{\prime} 47^{\prime \prime}$ & $116^{\circ} 02^{\prime} 05^{\prime \prime}$ & 15.8 & 4 & 4.0 & 5.38 \\
\hline 40 & 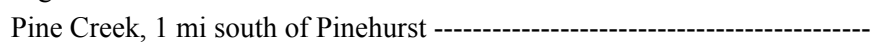 & $05 / 20 / 97$ & $47^{\circ} 31^{\prime} 09^{\prime \prime}$ & $116^{\circ} 14^{\prime} 26^{\prime \prime}$ & 25.3 & 1 & 2.0 & 5.70 \\
\hline 41 & 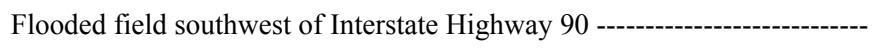 & $05 / 20 / 97$ & $47^{\circ} 34^{\prime} 03^{\prime \prime}$ & $116^{\circ} 24^{\prime} 47^{\prime \prime}$ & 37.9 & 15 & 1.4 & 7.41 \\
\hline 42 & Fourth of July Creek at mouth - & $05 / 20 / 97$ & $47^{\circ} 32^{\prime} 38^{\prime \prime}$ & $116^{\circ} 25^{\prime} 30^{\prime \prime}$ & 37.9 & 0.3 & 2.9 & 3.05 \\
\hline
\end{tabular}


Table 1. Analytical data for samples of suspended sediment collected from the Coeur d'Alene-Spokane River system, northern Idaho and eastern Washington, during high-water events in 1996 and 1997.-Continued

\begin{tabular}{|c|c|c|c|c|c|c|c|c|c|c|}
\hline Sample & Location & $\underset{(p p m)}{\text { As }}$ & $\begin{array}{c}\mathbf{B a} \\
(\mathbf{p p m})\end{array}$ & $\begin{array}{c}\text { Be } \\
\text { (ppm) }\end{array}$ & $\begin{array}{c}\text { Ca } \\
\text { (wt } \\
\text { pct) }\end{array}$ & $\underset{(p p m)}{\mathbf{C d}}$ & $\begin{array}{c}\text { Ce } \\
\text { (ppm) }\end{array}$ & $\begin{array}{c}\text { Co } \\
\text { (ppm) }\end{array}$ & $\underset{(\mathbf{p p m})}{\mathbf{C r}}$ & $\underset{(p p m)}{\text { Cs }}$ \\
\hline & & & \multicolumn{8}{|c|}{ Coeur d'Alene River, February 9-10, 1996} \\
\hline 1 & 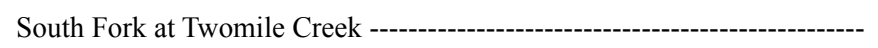 & 64 & 853 & 2.2 & 0.46 & 15.9 & 55 & 14 & na & 15 \\
\hline 2 & South Fork at the Smelterville bridge -- & 102 & 767 & 2.0 & 0.34 & 15.7 & 45 & 14 & na & 11 \\
\hline 3 & 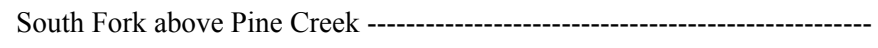 & 87 & 831 & 2.7 & 0.33 & 20.1 & 70 & 17 & na & 14 \\
\hline 4 & Coeur d'Alene River at Kingston ---1-- & 58 & 732 & 2.3 & 0.65 & 9.0 & 62 & 18 & na & 11 \\
\hline 5 & Coeur d'Alene River at the Idaho Highway 2 bridge at Cataldo----------- & 44 & 813 & 2.7 & 0.42 & 4.7 & 76 & 14 & na & 14 \\
\hline 6 & Coeur d'Alene River above Dudley -- & 72 & 897 & 3.3 & 0.53 & 9.8 & 75 & 17 & na & 16 \\
\hline 7 & Coeur d'Alene River below Rose Lake - & 44 & 880 & 3.0 & 0.53 & 7.4 & 68 & 16 & na & 16 \\
\hline 8 & Coeur d'Alene River at Anderson Lake inlet --- & 158 & 661 & 2.0 & 0.33 & 24.0 & 34 & 14 & na & 9 \\
\hline
\end{tabular}

Tributaries to the Coeur d'Alene River, February 9-10, 1996

\begin{tabular}{|c|c|c|c|c|c|c|c|c|c|c|}
\hline 9 & Canyon Creek at mouth -- & 64 & 593 & 2.3 & 0.48 & 63.1 & 35 & 19 & na & 11 \\
\hline 10 & Ninemile Creek at mouth ------- & 39 & 793 & 2.5 & 0.74 & 28.1 & 62 & 18 & na & 17 \\
\hline \multicolumn{11}{|c|}{ Coeur d'Alene River, January 2, 1997} \\
\hline \multirow[t]{2}{*}{11} & South Fork at Enaville -------------. & 61 & 634 & 2.2 & 0.26 & 36.9 & 74 & 16 & 47 & 13 \\
\hline & & & \multicolumn{8}{|c|}{ Tributaries to the Coeur d'Alene River, January 2, 1997} \\
\hline 12 & Canyon Creek at mouth ----------- & 63 & 525 & 2.6 & 0.57 & 77.9 & 72 & 24 & 45 & 12 \\
\hline 13 & 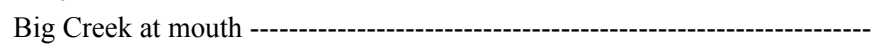 & 83 & 700 & 2.1 & 0.33 & 1.2 & 71 & 12 & 89 & 12 \\
\hline 14 & 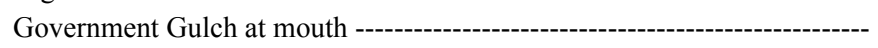 & 275 & 936 & 2.3 & 0.46 & 79.0 & 80 & 74 & 36 & 14 \\
\hline 15 & 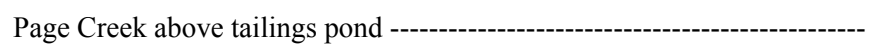 & 35 & 659 & 2.7 & 0.58 & 16.0 & 82 & 21 & 50 & 14 \\
\hline 16 & 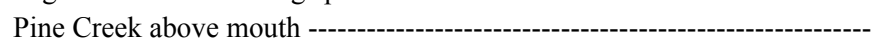 & 46 & 577 & 2.2 & 0.18 & 3.0 & 77 & 11 & 42 & 11 \\
\hline
\end{tabular}


Table 1. Analytical data for samples of suspended sediment collected from the Coeur d'Alene-Spokane River system, northern Idaho and eastern Washington, during high-water events in 1996 and 1997.-Continued

\begin{tabular}{|c|c|c|c|c|c|c|c|c|c|c|}
\hline Sample & Location & $\underset{(\mathrm{ppm})}{\text { As }}$ & $\underset{(\mathbf{p p m})}{\mathrm{Ba}}$ & $\underset{(\mathbf{p p m})}{\mathrm{Be}}$ & $\begin{array}{l}\mathrm{Ca} \\
\text { (wt } \\
\text { pct) }\end{array}$ & $\underset{(\mathbf{p p m})}{\mathbf{C d}}$ & $\begin{array}{c}\mathbf{C e} \\
(\mathbf{p p m})\end{array}$ & $\begin{array}{c}\text { Co } \\
\text { (ppm) }\end{array}$ & $\underset{(\mathbf{p p m})}{\mathbf{C r}}$ & $\underset{(\mathbf{p p m})}{\mathbf{C s}}$ \\
\hline & & \multicolumn{9}{|c|}{ Spokane River, May 2, 1997} \\
\hline 17 & Spokane River at the Stateline bridge & 30 & 602 & 2.3 & 0.93 & 28.5 & 87 & 18 & 50 & 9 \\
\hline 18 & Spokane River at the Centennial Trail bridge --о-о-о-о-о-о-о-о-о-о & 17 & 486 & 2.0 & 1.10 & 22.5 & 65 & 14 & 49 & 7 \\
\hline 19 & Spokane River at the Gonzaga University bridge & 49 & 665 & 2.8 & 1.09 & 28.6 & 95 & 19 & 82 & 11 \\
\hline 20 & Spokane River at the 7-Mile bridge --- & 23 & 761 & 2.4 & 1.58 & 12.9 & 100 & 19 & 71 & 10 \\
\hline
\end{tabular}

\begin{tabular}{|c|c|c|c|c|c|c|c|c|c|c|}
\hline \multirow[b]{2}{*}{21} & \multirow{2}{*}{ South Fork at Larsen ----1- } & \multirow[b]{2}{*}{25} & \multirow[b]{2}{*}{835} & \multicolumn{5}{|c|}{ Coeur d'Alene-Spokane Rivers, May 19-20, 199} & \multirow[b]{2}{*}{42} & \multirow[b]{2}{*}{16} \\
\hline & & & & 2.1 & 1.01 & 2.5 & 79 & 11 & & \\
\hline 22 & South Fork at Mullan - & 29 & 1,012 & 2.7 & 0.58 & 2.7 & 83 & 12 & 45 & 20 \\
\hline 23 & South Fork below the Morning Mine ------ & 36 & 1,113 & 2.7 & 0.59 & 5.3 & 95 & 13 & 34 & 22 \\
\hline 24 & South Fork above Canyon Creek --- & 20 & 1,025 & 2.0 & 0.31 & 5.4 & 63 & 9 & 34 & 18 \\
\hline 25 & South Fork at west end of Wallace -- & 22 & 884 & 1.8 & 0.33 & 9.8 & 64 & 9 & 33 & 16 \\
\hline 26 & South Fork at Twomile Creek & 27 & 1,034 & 2.2 & 0.40 & 14.2 & 74 & 12 & 42 & 19 \\
\hline 27 & South Fork at the Evolution bridge -- & 29 & 872 & 1.7 & 0.32 & 14.9 & 31 & 11 & 37 & 11 \\
\hline 28 & South Fork at Enaville - & 64 & 751 & 2.1 & 0.40 & 21.7 & 59 & 17 & 38 & 13 \\
\hline 29 & Coeur d'Alene River at the Idaho Highway 2 bridge at Cataldo-------- & 62 & 707 & 2.3 & 0.36 & 21.1 & 69 & 19 & 49 & 14 \\
\hline 30 & Coeur d'Alene River at the Idaho Highway 3 bridge -- & 46 & 711 & 2.6 & 0.31 & 10.3 & 52 & 25 & 60 & 11 \\
\hline 31 & Spokane River at the Idaho Highway 95 bridge -- & 38 & 619 & 2.5 & 0.82 & 17.1 & 86 & 23 & 73 & 11 \\
\hline 32 & Spokane River above the Post Falls dam -- & 33 & 557 & 2.0 & 1.19 & 35.5 & 80 & 16 & 20 & 8 \\
\hline 33 & Spokane River at the Stateline footbridge - & 39 & 589 & 2.1 & 1.09 & 66.6 & 86 & 18 & 61 & 10 \\
\hline 34 & Spokane River at Sullivan Rd - & 61 & 691 & 3.2 & 1.38 & 18.9 & 96 & 20 & 70 & 11 \\
\hline 35 & Spokane River at the Gonzaga University bridge --------- & 55 & 835 & 3.7 & 1.41 & 31.6 & 130 & 25 & 92 & 13 \\
\hline
\end{tabular}

Tributaries to Coeur d'Alene River, May 20, 1997

\begin{tabular}{|c|c|c|c|c|c|c|c|c|c|c|}
\hline 36 & Mill Creek above Mullan --- & 25 & 1,266 & 2.0 & 0.90 & 14.3 & 48 & 18 & 63 & 23 \\
\hline 37 & 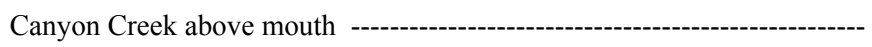 & 94 & 598 & 1.8 & 0.85 & 52.8 & 77 & 26 & 56 & 11 \\
\hline 38 & Ninemile Creek above mouth -------------- & 22 & 555 & 2.9 & 0.84 & 48.6 & 76 & 17 & 56 & 15 \\
\hline 39 & 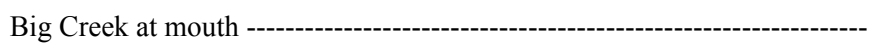 & 35 & 650 & 1.6 & 0.68 & 1.9 & 67 & 17 & 61 & 10 \\
\hline 40 & Pine Creek, 1 mi south of Pinehurst ------ & 24 & 498 & 2.1 & 0.74 & 2.3 & 66 & 12 & 68 & 9 \\
\hline 41 & Flooded field southwest of Interstate Highway 90 ----------------------- & 27 & 584 & 2.1 & 0.70 & 3.8 & 107 & 26 & 66 & 13 \\
\hline 42 & Fourth of July Creek at mouth - & 110 & 545 & 1.6 & 1.32 & 24.6 & 66 & 21 & 74 & 5 \\
\hline
\end{tabular}


Table 1. Analytical data for samples of suspended sediment collected from the Coeur d'Alene-Spokane River system, northern Idaho and eastern Washington, during high-water events in 1996 and 1997.-Continued

Sample Location

\begin{tabular}{|c|c|c|c|}
\hline $\begin{array}{c}\text { Cu } \\
\text { (ppm) }\end{array}$ & $\begin{array}{l}\text { Fe } \\
\text { (wt } \\
\text { pct) }\end{array}$ & $\underset{(\mathrm{ppm})}{\mathbf{G a}}$ & $\begin{array}{c}\text { K } \\
\text { (wt } \\
\text { pct }\end{array}$ \\
\hline
\end{tabular}

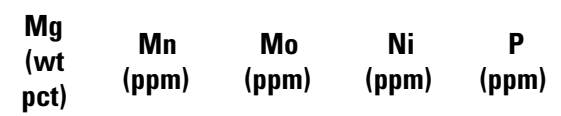

\begin{tabular}{|c|c|c|c|c|c|c|c|c|c|c|c|}
\hline \multicolumn{12}{|c|}{ Coeur d'Alene River, February 9-10, 1996} \\
\hline 1 & South Fork at Twomile Creek -- & 113 & 4.69 & 15 & 2.99 & 24 & 0.76 & 2,770 & 1 & 27 & 606 \\
\hline 2 & South Fork at the Smelterville bridge ---------- & 139 & 6.50 & 14 & 2.69 & 19 & 0.60 & 4,318 & 1 & 20 & 515 \\
\hline 3 & 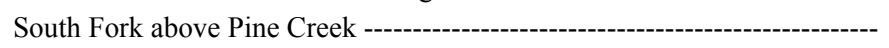 & 119 & 5.31 & 19 & 3.25 & 31 & 0.75 & 3,182 & 2 & 36 & 592 \\
\hline 4 & Coeur d'Alene River at Kingston -- & 82 & 4.82 & 17 & 2.76 & 27 & 0.81 & 2,092 & 3 & 22 & 753 \\
\hline 5 & Coeur d'Alene River at the Idaho Highway 2 bridge at Cataldo------------ & 59 & 4.24 & 19 & 3.15 & 32 & 0.95 & 1,330 & 1 & 24 & 665 \\
\hline 6 & 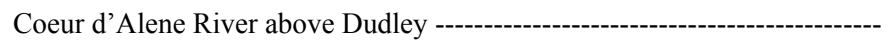 & 106 & 5.91 & 22 & 3.84 & 30 & 1.13 & 2,306 & 2 & 41 & 823 \\
\hline 7 & Coeur d'Alene River below Rose Lake --- & 72 & 5.83 & 22 & 3.61 & 28 & 1.23 & 1,776 & 2 & 33 & 845 \\
\hline 8 & Coeur d'Alene River at Anderson Lake inlet --- & 122 & 10.10 & 13 & 2.42 & 14 & 0.76 & 7,882 & 1 & 21 & 473 \\
\hline
\end{tabular}

\begin{tabular}{|c|c|c|c|c|c|c|c|c|c|c|c|}
\hline \multicolumn{12}{|c|}{ Tributaries to the Coeur d'Alene River, February 9-10, 1996} \\
\hline 9 & Canyon Creek at mouth --------------- & 322 & 6.40 & 13 & 2.29 & 15 & 0.50 & 3,771 & 7 & 223 & 568 \\
\hline 10 & Ninemile Creek at mouth --1-- & 186 & 5.42 & 17 & 2.75 & 27 & 0.60 & 2,831 & 2 & 30 & 991 \\
\hline \multicolumn{12}{|c|}{ Coeur d'Alene River, January 2, 1997} \\
\hline 11 & 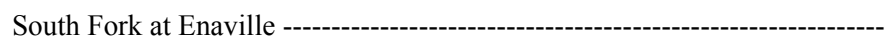 & 111 & 4.06 & 16 & 2.76 & 32 & 0.54 & 2,573 & 1 & 24 & 478 \\
\hline \multicolumn{12}{|c|}{ Tributaries to the Coeur d'Alene River, January 2, 1997} \\
\hline 12 & Canyon Creek at mouth --------------- & 412 & 5.61 & 15 & 2.34 & 31 & 0.50 & 4,515 & 3 & 27 & 1,071 \\
\hline 13 & Big Creek at mouth -- & 122 & 2.84 & 14 & 3.28 & 31 & 0.60 & 1,308 & 1 & 22 & 453 \\
\hline 14 & Government Gulch at mouth -------- & 1,401 & 3.54 & 18 & 2.30 & 35 & 0.42 & 2,291 & 4 & 34 & 803 \\
\hline 15 & 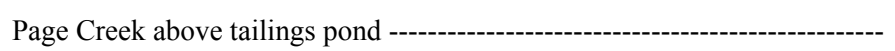 & 87 & 3.48 & 18 & 3.06 & 38 & 0.53 & 1,328 & 2 & 29 & 660 \\
\hline 16 & Pine Creek above mouth & 54 & 3.32 & 17 & 3.39 & 32 & 0.53 & 620 & 1 & 19 & 362 \\
\hline
\end{tabular}


Table 1. Analytical data for samples of suspended sediment collected from the Coeur d'Alene-Spokane River system, northern Idaho and eastern Washington, during high-water events in 1996 and 1997.-Continued

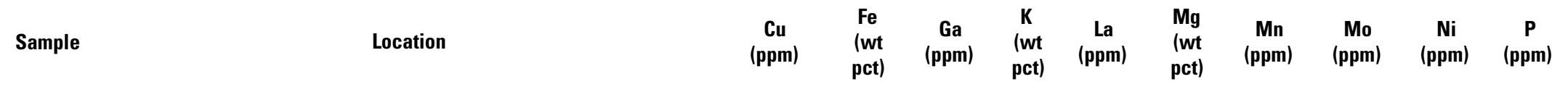

Spokane River, May 2, 1997

\begin{tabular}{|c|c|c|c|c|c|c|c|c|c|c|c|}
\hline 17 & Spokane River at the Stateline bridge & 103 & 4.70 & 16 & 1.72 & 32 & 1.13 & 2,871 & 1 & 45 & 1,267 \\
\hline 18 & Spokane River at the Centennial Trail bridge & 127 & 3.46 & 13 & 1.54 & 26 & 0.92 & 1,840 & 1 & 36 & 995 \\
\hline 19 & Spokane River at the Gonzaga University bridge & 98 & 4.65 & 17 & 1.99 & 37 & 1.28 & 2,735 & 2 & 42 & 1,392 \\
\hline 20 & Spokane River at the 7-Mile bridge & 57 & 5.33 & 20 & 2.34 & 44 & 1.33 & 1,660 & 1 & 37 & 1,381 \\
\hline
\end{tabular}

Coeur d'Alene-Spokane Rivers, May 19-20, 1997

\begin{tabular}{|c|c|c|c|c|c|c|c|c|c|c|c|}
\hline 21 & South Fork at Larsen ----. & 58 & 2.65 & 14 & 2.26 & 35 & 0.70 & 1,303 & 1 & 22 & 1,004 \\
\hline 22 & South Fork at Mullan ---------- & 310 & 3.08 & 16 & 3.15 & 36 & 0.76 & 2,147 & 2 & 24 & 891 \\
\hline 23 & South Fork below the Morning Mine & 269 & 3.20 & 16 & 3.83 & 41 & 0.78 & 2,211 & 2 & 21 & 715 \\
\hline 24 & South Fork above Canyon Creek & 114 & 2.87 & 13 & 2.82 & 25 & 0.62 & 1,626 & 1 & 16 & 415 \\
\hline 25 & South Fork at west end of Wallace & 103 & 2.71 & 13 & 2.66 & 27 & 0.59 & 1,574 & 1 & 15 & 377 \\
\hline 26 & South Fork at Twomile Creek --- & 120 & 3.37 & 16 & 3.16 & 32 & 0.75 & 1,936 & 1 & 21 & 462 \\
\hline 27 & South Fork at the Evolution bridge & 127 & 3.08 & 14 & 2.70 & 11 & 0.62 & 1,818 & 1 & 17 & 390 \\
\hline 28 & 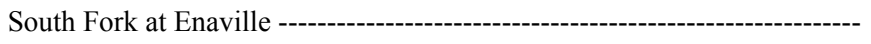 & 112 & 3.98 & 15 & 2.56 & 22 & 0.64 & 3,042 & 1 & 20 & 464 \\
\hline 29 & Coeur d'Alene River at the Idaho Highway 2 bridge at Cataldo--------- & 96 & 4.13 & 15 & 2.70 & 29 & 0.67 & 3,355 & 1 & 26 & 662 \\
\hline 30 & Coeur d'Alene River at the Idaho Highway 3 bridge & 82 & 4.78 & 18 & 2.62 & 19 & 0.66 & 1,931 & 2 & 37 & 671 \\
\hline 31 & Spokane River at the Idaho Highway 95 bridge & 276 & 5.59 & 17 & 2.06 & 35 & 0.92 & 3,681 & 2 & 53 & 1,930 \\
\hline 32 & Spokane River above the Post Falls dam ---о-о-о-о-о-о-о-о-о-о-о-о-о & 100 & 4.10 & 15 & 1.71 & 31 & 1.00 & 1,890 & 2 & 33 & 1,354 \\
\hline 33 & Spokane River at the Stateline footbridge & 299 & 4.53 & 15 & 1.85 & 32 & 1.10 & 2,415 & 1 & 39 & 1,470 \\
\hline 34 & Spokane River at Sullivan Rd & 127 & 4.86 & 18 & 2.24 & 38 & 1.46 & 2,296 & 2 & 42 & 1,600 \\
\hline 35 & Spokane River at the Gonzaga University bridge --- & 288 & 6.42 & 22 & 2.64 & 52 & 1.69 & 3,423 & 2 & 62 & 2,041 \\
\hline
\end{tabular}

Tributaries to Coeur d'Alene River, May 20, 1997

\begin{tabular}{|c|c|c|c|c|c|c|c|c|c|c|c|}
\hline 36 & Mill Creek above Mullan ------- & 89 & 3.15 & 13 & 2.00 & 20 & 0.29 & 5,145 & 2 & 36 & 1,065 \\
\hline 37 & Canyon Creek above mouth --о-о-о-о-о- & 265 & 5.57 & 14 & 2.27 & 33 & 0.43 & 3,408 & 5 & 33 & 589 \\
\hline 38 & Ninemile Creek above mouth ------ & 197 & 4.41 & 16 & 2.30 & 35 & 0.44 & 2,699 & 3 & 39 & 1,000 \\
\hline 39 & Big Creek at mouth ---- & 93 & 2.88 & 12 & 2.23 & 29 & 0.66 & 1,297 & 2 & 33 & 581 \\
\hline 40 & Pine Creek, $1 \mathrm{mi}$ south of Pinehurst & 165 & 3.19 & 13 & 2.05 & 31 & 0.54 & 936 & 2 & 44 & 945 \\
\hline 41 & Flooded field southwest of Interstate Highway 90 - & 67 & 5.09 & 15 & 1.82 & 41 & 0.57 & 1,934 & 2 & 55 & 1,542 \\
\hline 42 & Fourth of July Creek at mouth - & 176 & 10.77 & 8 & 0.70 & 27 & 0.62 & 6,756 & 3 & 94 & 3,272 \\
\hline
\end{tabular}


Table 1. Analytical data for samples of suspended sediment collected from the Coeur d'Alene-Spokane River system, northern Idaho and eastern Washington, during high-water events in 1996 and 1997.-Continued

Sample

Location

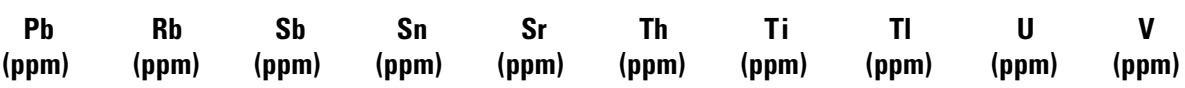

Coeur d'Alene River, February 9-10, 1996

South Fork at Twomile Creek

$4,035 \quad 147$

147

$6,360 \quad 129$

South Fork at the Smelterville bridge

South Fork above Pine Creek

164

Coeur d'Alene River at Kingston -

$1,765 \quad 136$

Coeur d'Alene River at the Idaho Highway 2 bridge at Cataldo-------s

Coeur d'Alene River above Dudley

Coeur d'Alene River below Rose Lake -

$2,480 \quad 194$

Coeur d'Alene River at Anderson Lake inlet

$2,060 \quad 184$

$5,925 \quad 112$

Tributaries to the Coeur d'Alene River, February 9-10, 1996

\begin{tabular}{|c|c|c|c|c|c|c|c|c|c|c|c|}
\hline 9 & Canyon Creek at mouth - & 17,310 & 110 & 181 & 10 & 75 & 9 & 1,628 & 0.65 & 4.4 & 45 \\
\hline 10 & Ninemile Creek at mouth -- & 11,280 & 130 & 87 & 1 & 174 & 13 & 2,333 & 0.80 & 6.8 & 69 \\
\hline \multicolumn{12}{|c|}{ Coeur d'Alene River, January 2, 1997} \\
\hline 11 & 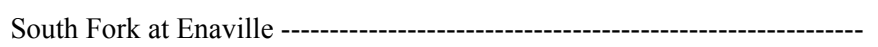 & 3,832 & 157 & 28 & 4 & 52 & 15 & 1,813 & 0.9 & 3 & 66 \\
\hline \multicolumn{12}{|c|}{ Tributaries to the Coeur d'Alene River, January 2, 1997} \\
\hline 12 & 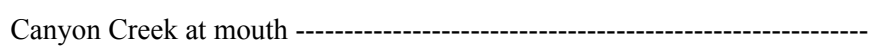 & 13,929 & 126 & 136 & 8 & 75 & 13 & 1,834 & 0.9 & 5 & 52 \\
\hline 13 & 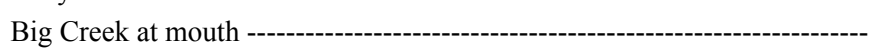 & 294 & 141 & 42 & 3 & 40 & 13 & 1,321 & 0.9 & 3 & 53 \\
\hline 14 & 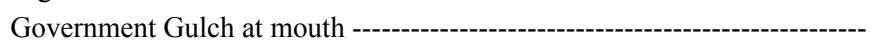 & 3,087 & 147 & 73 & 8 & 103 & 16 & 2,747 & 2.0 & 5 & 76 \\
\hline 15 & 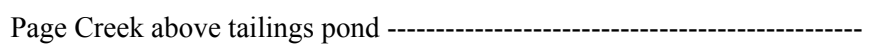 & 3,693 & 154 & 26 & 4 & 96 & 17 & 2,318 & 1.0 & 4 & 73 \\
\hline 16 & Pine Creek above mouth & 674 & 168 & 9 & 4 & 45 & 14 & 1,630 & 0.8 & 2 & 69 \\
\hline
\end{tabular}


Table 1. Analytical data for samples of suspended sediment collected from the Coeur d'Alene-Spokane River system, northern Idaho and eastern Washington, during high-water events in 1996 and 1997.-Continued
Sample
Location

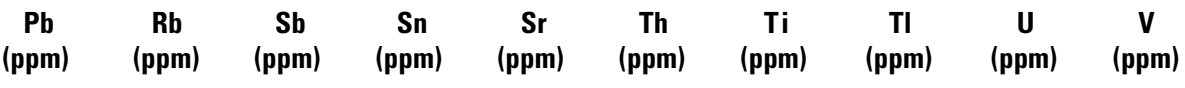

Spokane River, May 2, 1997

\begin{tabular}{|c|c|c|c|c|c|c|c|c|c|c|c|}
\hline 17 & Spokane River at the Stateline bridge -- & 1,404 & 110 & 9 & 4 & 98 & 15 & 3,074 & 0.7 & 5 & 80 \\
\hline 18 & 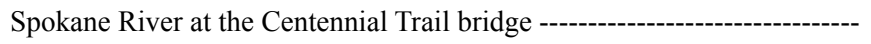 & 898 & 88 & 7 & 6 & 106 & 11 & 2,916 & 0.7 & 4 & 60 \\
\hline 19 & Spokane River at the Gonzaga University bridge & 1,293 & 123 & 8 & 7 & 118 & 17 & 3,363 & 0.8 & 7 & 85 \\
\hline 20 & Spokane River at the 7-Mile bridge & 532 & 139 & 4 & 5 & 189 & 18 & 2,285 & 0.8 & 5 & 129 \\
\hline
\end{tabular}

Coeur d'Alene-Spokane Rivers, May 19-20, 1997

\begin{tabular}{|c|c|c|c|c|c|c|c|c|c|c|c|}
\hline 21 & South Fork at Larsen ------ & 180 & 132 & 4 & 3 & 97 & 13 & 1,924 & 0.7 & 9 & 52 \\
\hline 22 & South Fork at Mullan -- & 510 & 172 & 15 & 4 & 63 & 15 & 1,720 & 1.2 & 7 & 59 \\
\hline 23 & South Fork below the Morning Mine & 846 & 185 & 15 & 14 & 61 & 16 & 1,373 & 1.2 & 5 & 60 \\
\hline 24 & 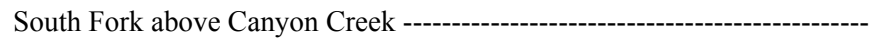 & 929 & 155 & 13 & 4 & 35 & 13 & 1,760 & 0.9 & 3 & 49 \\
\hline 25 & 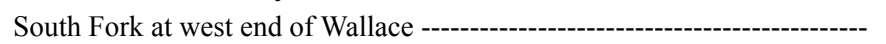 & 1,563 & 150 & 15 & 4 & 41 & 12 & 1,128 & 0.9 & 3 & 45 \\
\hline 26 & 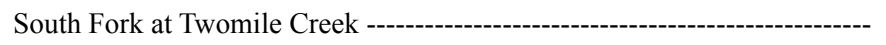 & 2,096 & 187 & 22 & 5 & 50 & 15 & 1,738 & 1.1 & 4 & 57 \\
\hline 27 & South Fork at the Evolution bridge & 2,098 & 110 & 21 & 4 & 41 & 9 & 1,368 & 0.9 & 3 & 51 \\
\hline 28 & South Fork at Enaville & 2,618 & 133 & 32 & 3 & 81 & 12 & 1,811 & 0.9 & 3 & 58 \\
\hline 29 & Coeur d'Alene River at the Idaho Highway 2 bridge at Cataldo------- & 1,909 & 147 & 19 & 4 & 60 & 14 & 1,733 & 0.9 & 5 & 61 \\
\hline 30 & Coeur d'Alene River at the Idaho Highway 3 bridge -- & 1,233 & 99 & 13 & 4 & 58 & 10 & 2,331 & 0.8 & 3 & 75 \\
\hline 31 & Spokane River at the Idaho Highway 95 bridge -- & 2,318 & 132 & 13 & 14 & 62 & 17 & 2,580 & 0.9 & 5 & 67 \\
\hline 32 & Spokane River above the Post Falls dam -- & 1,275 & 105 & 8 & 30 & 116 & 14 & 3,102 & 0.8 & 5 & 76 \\
\hline 33 & Spokane River at the Stateline footbridge - & 1,611 & 118 & 11 & 9 & 106 & 15 & 3,043 & 0.8 & 6 & 79 \\
\hline 34 & 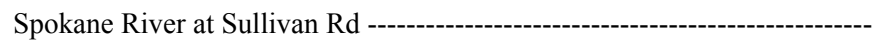 & 1,324 & 139 & 8 & 19 & 151 & 19 & 2,565 & 1.0 & 9 & 94 \\
\hline 35 & Spokane River at the Gonzaga University bridge - & 2,015 & 164 & 12 & 10 & 145 & 26 & 2,790 & 1.1 & 8 & 112 \\
\hline
\end{tabular}

Tributaries to the Coeur d'Alene River, May 20, 1997

\begin{tabular}{|c|c|c|c|c|c|c|c|c|c|c|c|}
\hline 36 & 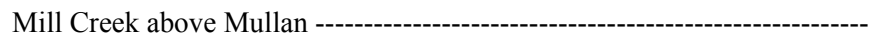 & 3,005 & 130 & 13 & 6 & 78 & 12 & 1,553 & 0.9 & 6 & 51 \\
\hline 37 & 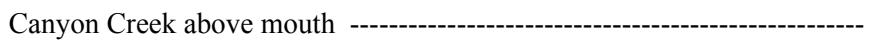 & 9,793 & 124 & 126 & 8 & 123 & 15 & 2,106 & 0.7 & 4 & 52 \\
\hline 38 & 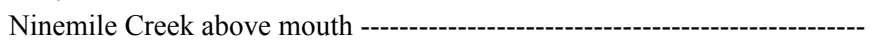 & 10,100 & 132 & 46 & 9 & 206 & 16 & 2,228 & 0.8 & 8 & 68 \\
\hline 39 & Big Creek at mouth --------------------------------- & 224 & 119 & 51 & 4 & 80 & 11 & 1,995 & 0.8 & 4 & 48 \\
\hline 40 & 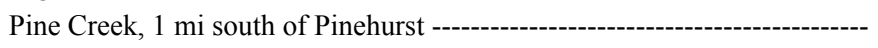 & 698 & 130 & 7 & 8 & 80 & 15 & 2,250 & 0.7 & 3 & 44 \\
\hline 41 & 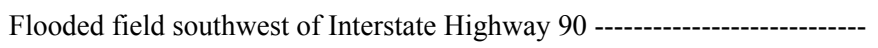 & 398 & 107 & 4 & 3 & 101 & 15 & 2,269 & 0.6 & 3 & 67 \\
\hline 42 & Fourth of July Creek at mouth --- & 929 & 49 & 5 & 6 & 110 & 11 & 1,480 & 0.3 & 2 & 58 \\
\hline
\end{tabular}


Table 1. Analytical data for samples of suspended sediment collected from the Coeur d'Alene-Spokane River 
Table 1. Analytical data for samples of suspended sediment collected from the Coeur d'Alene-Spokane River system, northern Idaho and eastern Washington, during high-water events in 1996 and 1997.-Continued

\begin{tabular}{|c|c|c|c|c|c|}
\hline Sample & Location & $\underset{(\mathrm{ppm})}{\mathbf{W}}$ & $\begin{array}{c}\mathbf{Y} \\
(\mathbf{p p m})\end{array}$ & $\begin{array}{c}\mathrm{Zn} \\
(\mathrm{ppm})\end{array}$ & $\begin{array}{c}\mathrm{Zr} \\
(\mathrm{ppm})\end{array}$ \\
\hline \multicolumn{6}{|c|}{ Spokane River, May 2, 1997} \\
\hline 17 & Spokane River at the Stateline bridge -------------------------------. & 4 & 28 & 3,068 & 84 \\
\hline 18 & 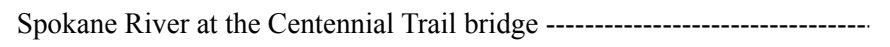 & 7 & 21 & 2,430 & 65 \\
\hline 19 & Spokane River at the Gonzaga University bridge ------- & 9 & 31 & 3,169 & 96 \\
\hline 20 & Spokane River at the 7-Mile bridge --- & 3 & 33 & 1,690 & 110 \\
\hline \multicolumn{6}{|c|}{ Coeur d'Alene-Spokane Rivers, May 19-20, 1997} \\
\hline 21 & South Fork at Larsen -- & 3 & 20 & 378 & 63 \\
\hline 22 & 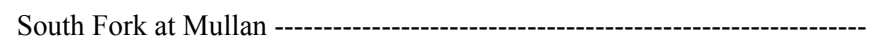 & 2 & 17 & 482 & 72 \\
\hline 23 & South Fork below the Morning Mine - & 2 & 15 & 907 & 58 \\
\hline 24 & South Fork above Canyon Creek --- & 3 & 13 & 889 & 84 \\
\hline 25 & South Fork at west end of Wallace -- & 3 & 15 & 1,625 & 51 \\
\hline 26 & South Fork at Twomile Creek --- & 3 & 14 & 2,433 & 68 \\
\hline 27 & South Fork at the Evolution bridge -- & 2 & 7 & 2,494 & 64 \\
\hline 28 & South Fork at Enaville -- & 3 & 11 & 3,805 & 67 \\
\hline 29 & Coeur d'Alene River at the Idaho Highway 2 bridge at Cataldo---------. & 3 & 15 & 3,762 & 70 \\
\hline 30 & Coeur d'Alene River at the Idaho Highway 3 bridge --- & 3 & 12 & 2,403 & 68 \\
\hline 31 & Spokane River at the Idaho Highway 95 bridge ------ & 39 & 29 & 3,708 & 95 \\
\hline 32 & Spokane River above the Post Falls dam --- & 12 & 31 & 3,046 & 45 \\
\hline 33 & Spokane River at the Stateline footbridge - & 7 & 31 & 3,440 & 94 \\
\hline 34 & Spokane River at Sullivan Rd -- & 11 & 35 & 3,489 & 87 \\
\hline 35 & Spokane River at the Gonzaga University bridge ---------------------- & 9 & 36 & 4,234 & 93 \\
\hline
\end{tabular}

Tributaries to the Coeur d'Alene River, May 20, 1997

\begin{tabular}{|c|c|c|c|c|c|}
\hline 36 & 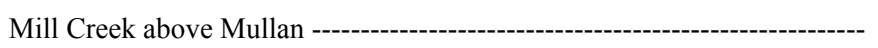 & 4 & 13 & 2,038 & 68 \\
\hline 37 & 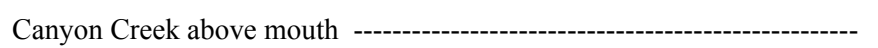 & 6 & 14 & 5,818 & 50 \\
\hline 38 & Ninemile Creek above mouth --------- & 7 & 21 & 9,398 & 59 \\
\hline 39 & Big Creek at mouth --- & 9 & 16 & 492 & 55 \\
\hline 40 & Pine Creek, 1 mi south of Pinehurst - & 12 & 14 & 1,264 & 56 \\
\hline 41 & 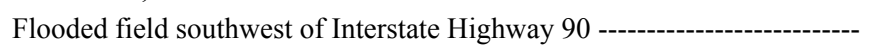 & 5 & 24 & 561 & 70 \\
\hline 42 & 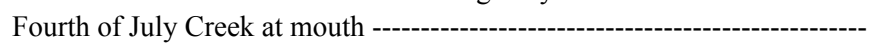 & 9 & 27 & 2,401 & 58 \\
\hline
\end{tabular}


Table 2. Analytical data for samples of overbank sediment from the South Fork and main stem of the Coeur d'Alene River, northern Idaho, deposited during high-water events in 1995 and 1996

[See figure 3 for locations. Samples are grouped by sampling data and depositional environment (streambank or marsh) and listed from upstream to downstream]

\begin{tabular}{|c|c|c|c|c|c|}
\hline Sample & Location & Lithology & $\begin{array}{l}\text { Latitude } \\
\mathbf{N} .\end{array}$ & $\begin{array}{l}\text { Longitude } \\
\text { W. }\end{array}$ & $\begin{array}{c}\text { Sampling } \\
\text { date }\end{array}$ \\
\hline \multicolumn{6}{|c|}{ Coeur d'Alene River streambank sediment deposited after February 21, 1995 flow peak } \\
\hline 43 & North bank above the Idaho Highway 2 bridge ---------------- & Coarse sand & $47^{\circ} 32^{\prime} 57^{\prime \prime}$ & $116^{\circ} 20^{\prime} 03^{\prime \prime}$ & $02 / 23 / 95$ \\
\hline 44 & North bank above the Idaho Highway 2 bridge ------------- & Silt to fine sand & $47^{\circ} 32^{\prime} 57^{\prime \prime}$ & $116^{\circ} 20^{\prime} 03^{\prime \prime}$ & $02 / 23 / 95$ \\
\hline 45 & 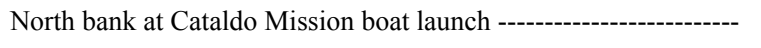 & Silty mud & $47^{\circ} 33^{\prime} 13^{\prime \prime}$ & $116^{\circ} 21^{\prime} 59^{\prime \prime}$ & $02 / 23 / 95$ \\
\hline 46 & North bank above Fourth of July Creek --------------------- & Fine sand & $47^{\circ} 32^{\prime} 37^{\prime \prime}$ & $116^{\circ} 25^{\prime} 23^{\prime \prime}$ & $02 / 23 / 95$ \\
\hline 47 & South bank below the Rose Lake bridge -- & Fine sand & $47^{\circ} 32^{\prime} 10^{\prime \prime}$ & $116^{\circ} 28^{\prime} 19^{\prime \prime}$ & $02 / 23 / 95$ \\
\hline 48 & North bank above the Idaho Highway 3 bridge ------------------- & Fine sand & $47^{\circ} 31^{\prime} 27^{\prime \prime}$ & $116^{\circ} 30^{\prime} 47^{\prime \prime}$ & $02 / 23 / 95$ \\
\hline \multicolumn{6}{|c|}{ Coeur d'Alene River streambank sediment deposited after February 9, 1996 flow peak } \\
\hline 49 & South bank below the Smelterville bridge ------- & Medium to coarse sand & $47^{\circ} 32^{\prime} 55^{\prime \prime}$ & $116^{\circ} 10^{\prime} 30^{\prime \prime}$ & $03 / 28 / 96$ \\
\hline 50 & 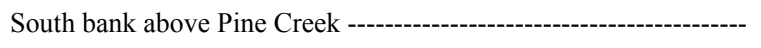 & Muddy silt & $47^{\circ} 32^{\prime} 54^{\prime \prime}$ & $116^{\circ} 13^{\prime} 13^{\prime \prime}$ & $03 / 28 / 96$ \\
\hline 51 & South bank at Kingston -- & Silty fine sand & $47^{\circ} 33^{\prime} 07^{\prime \prime}$ & $116^{\circ} 16^{\prime} 28^{\prime \prime}$ & $03 / 28 / 96$ \\
\hline 52 & 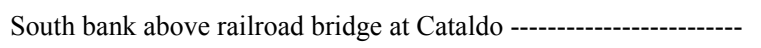 & Fine sand & $47^{\circ} 33^{\prime} 22^{\prime \prime}$ & $116^{\circ} 19^{\prime} 12^{\prime \prime}$ & $03 / 28 / 96$ \\
\hline 53 & North bank above the Idaho Highway 2 bridge -------------- & Medium to coarse sand & $47^{\circ} 32^{\prime} 55^{\prime \prime}$ & $116^{\circ} 20^{\prime} 04^{\prime \prime}$ & $03 / 28 / 96$ \\
\hline 54 & North bank at the Mission boat launch ------_--- & Muddy silt & $47^{\circ} 33^{\prime} 10^{\prime \prime}$ & $116^{\circ} 21^{\prime} 57^{\prime \prime}$ & $03 / 28 / 96$ \\
\hline 55 & South bank below the Rose Lake bridge -- & Fine sand & $47^{\circ} 32^{\prime} 10^{\prime \prime}$ & $116^{\circ} 28^{\prime} 19^{\prime \prime}$ & $03 / 28 / 96$ \\
\hline 56 & North bank 1 mi above the Idaho Highway 3 bridge ---------- & Medium sand & $47^{\circ} 32^{\prime} 05^{\prime \prime}$ & $116^{\circ} 30^{\prime} 33^{\prime \prime}$ & $03 / 28 / 96$ \\
\hline 57 & South bank at the Medimont boat launch ------ & Fine to medium sand & $47^{\circ} 28^{\prime} 40^{\prime \prime}$ & $116^{\circ} 35^{\prime} 37^{\prime \prime}$ & $03 / 28 / 96$ \\
\hline 58 & North bank at the Thompson Lake inlet boat launch --------- & Very fine sand & $47^{\circ} 29^{\prime} 08^{\prime \prime}$ & $116^{\circ} 43^{\prime} 26^{\prime \prime}$ & $04 / 12 / 96$ \\
\hline 59 & 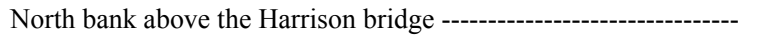 & Silt to fine sand & $47^{\circ} 27^{\prime} 58^{\prime \prime}$ & $116^{\circ} 45^{\prime} 49^{\prime \prime}$ & $04 / 12 / 96$ \\
\hline
\end{tabular}

Coeur d'Alene River floodplain marsh sediment deposited after February 9, 1996 flow peak

\begin{tabular}{|c|c|c|c|c|c|}
\hline 60 & Field near the town of Cataldo - & Silty mud & $47^{\circ} 33^{\prime} 14^{\prime \prime}$ & $116^{\circ} 19^{\prime} 21^{\prime \prime}$ & 03/28/96 \\
\hline 61 & 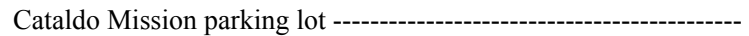 & Silty mud & $47^{\circ} 33^{\prime} 04^{\prime \prime}$ & $116^{\circ} 21^{\prime} 31^{\prime \prime}$ & $03 / 28 / 96$ \\
\hline 62 & Lane Marsh, south edge ---- & Clay to fine silt & $47^{\circ} 30^{\prime} 33^{\prime \prime}$ & $116^{\circ} 31^{\prime} 39^{\prime \prime}$ & $03 / 28 / 96$ \\
\hline 63 & Medicine Lake marsh --------------------------------------------- & Silt & $47^{\circ} 28^{\prime} 38^{\prime \prime}$ & $116^{\circ} 35^{\prime} 24^{\prime \prime}$ & $03 / 28 / 96$ \\
\hline 64 & Cave Lake, southeast shore - & Clay to fine silt & $47^{\circ} 28^{\prime} 04^{\prime \prime}$ & $116^{\circ} 35^{\prime} 20^{\prime \prime}$ & 03/28/96 \\
\hline 65 & Bare Marsh, west edge --------- & Fine silt & $47^{\circ} 29^{\prime} 11^{\prime \prime}$ & $116^{\circ} 43^{\prime} 15^{\prime \prime}$ & $04 / 12 / 96$ \\
\hline 66 & Thompson Lake, north shore -- & Fine silt & $47^{\circ} 29^{\prime} 38^{\prime \prime}$ & $116^{\circ} 43^{\prime} 51^{\prime \prime}$ & $04 / 12 / 96$ \\
\hline
\end{tabular}


Table 2. Analytical data for samples of overbank sediment from the South Fork and main stem of the Coeur d'Alene River, northern Idaho, deposited during high-water events in 1995 and 1996.-Continued

\begin{tabular}{|c|c|c|c|c|c|c|c|c|c|c|}
\hline Sample & Location & $\begin{array}{l}\text { River miles } \\
\text { below Mullan, } \\
\text { Idaho }\end{array}$ & $\underset{(p p m)}{\mathbf{A g}}$ & $\begin{array}{l}\text { Al } \\
\text { (wt } \\
\text { pct) }\end{array}$ & $\underset{(\mathrm{ppm})}{\text { As }}$ & $\begin{array}{r}\text { Ba } \\
(\mathbf{p p m})\end{array}$ & $\begin{array}{c}\text { Be } \\
\text { (ppm) }\end{array}$ & $\begin{array}{l}\text { Ca } \\
\text { (wt } \\
\text { pct) }\end{array}$ & $\underset{(p p m)}{\text { Cd }}$ & $\underset{\text { (ppm) }}{\text { Ce }}$ \\
\hline
\end{tabular}

\begin{tabular}{|c|c|c|c|c|c|c|c|c|c|c|}
\hline \multicolumn{11}{|c|}{ Coeur d'Alene River streambank sediment deposited after February 21, 1995 flow peak } \\
\hline 43 & North bank above the Idaho Highway 2 bridge -------------- & 32.0 & 2.8 & 4.44 & 52 & 442 & 1.1 & 0.12 & 4.5 & 50 \\
\hline 44 & North bank above the Idaho Highway 2 bridge --------- & 32.0 & 2.8 & 4.72 & 72 & 502 & 1.2 & 0.32 & 8.6 & 63 \\
\hline 45 & 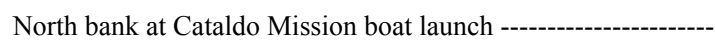 & 34.4 & 15.1 & 3.59 & 224 & 428 & 1.2 & 0.25 & 11.2 & 29 \\
\hline 46 & North bank above Fourth of July Creek ------------------- & 37.8 & 12.3 & 3.70 & 118 & 563 & 1.0 & 0.35 & 43.0 & 44 \\
\hline 47 & South bank below the Rose Lake bridge -- & 40.8 & 12.5 & 3.46 & 111 & 577 & 0.9 & 0.36 & 49.7 & 32 \\
\hline 48 & North bank above the Idaho Highway 3 bridge --- & 44.1 & 10.7 & 2.86 & 110 & 529 & 0.8 & 0.35 & 43.3 & 35 \\
\hline
\end{tabular}

\begin{tabular}{|c|c|c|c|c|c|c|c|c|c|c|}
\hline \multicolumn{11}{|c|}{ Coeur d'Alene River streambank sediment deposited after February 9, 1996 flow peak } \\
\hline 49 & South bank below the Smelterville bridge ------ & 22.4 & 11.2 & 5.11 & 90 & 654 & 1.9 & 0.31 & 13.3 & 36 \\
\hline 50 & 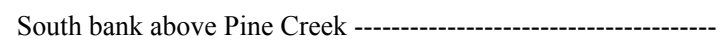 & 24.9 & 18.6 & 5.13 & 103 & 678 & 1.7 & 0.37 & 22.7 & 32 \\
\hline 51 & 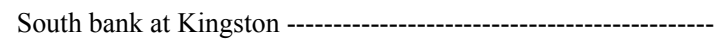 & 27.9 & 8.7 & 6.51 & 83 & 677 & 2.1 & 0.48 & 10.7 & 44 \\
\hline 52 & South bank above railroad bridge at Cataldo ------- & 31.0 & 8.6 & 5.61 & 68 & 555 & 1.6 & 0.35 & 9.6 & 53 \\
\hline 53 & North bank above the Idaho Highway 2 bridge ----------- & 32.0 & 6.7 & 6.18 & 81 & 643 & 2.1 & 0.27 & 8.4 & 34 \\
\hline 54 & North bank at the Mission boat launch -- & 34.4 & 6.6 & 7.62 & 68 & 676 & 2.1 & 0.45 & 8.5 & 71 \\
\hline 55 & South bank below the Rose Lake bridge -------------- & 40.8 & 17.8 & 3.84 & 78 & 503 & 1.1 & 0.31 & 41.9 & 31 \\
\hline 56 & North bank $1 \mathrm{mi}$ above the Idaho Highway 3 bridge --- & 43.2 & 15.7 & 5.39 & 109 & 734 & 1.6 & 0.44 & 46.6 & 47 \\
\hline 57 & South bank at the Medimont boat launch ------------------- & 50.9 & 14.3 & 3.44 & 99 & 518 & 1.1 & 0.42 & 31.3 & 29 \\
\hline 58 & North bank at the Thompson Lake inlet boat launch ---------- & 59.0 & 15.1 & 4.05 & 141 & 571 & 1.4 & 0.41 & 24.4 & 31 \\
\hline 59 & North bank above the Harrison bridge -- & 61.4 & 15.8 & 3.29 & 135 & 509 & 1.1 & 0.31 & 29.8 & 23 \\
\hline
\end{tabular}

Coeur d'Alene River floodplain marsh sediment deposited after February 9, 1996 flow peak

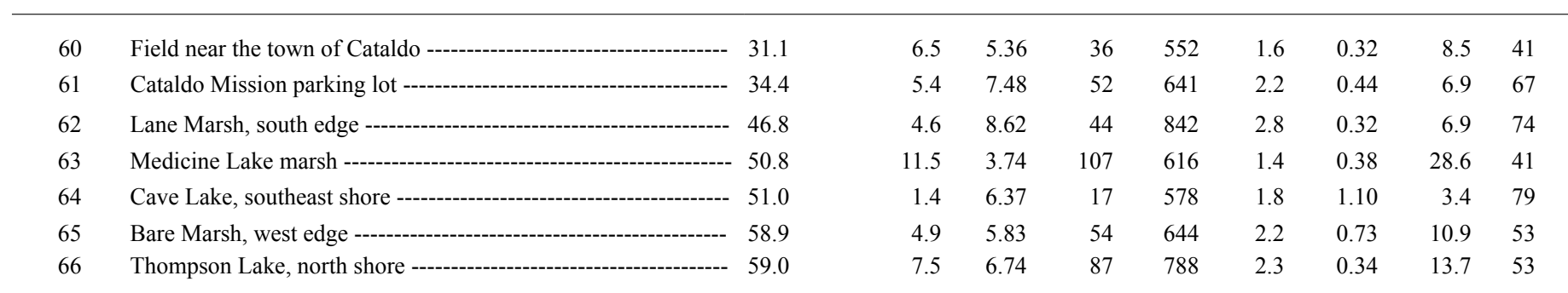


Table 2. Analytical data for samples of overbank sediment from the South Fork and main stem of the Coeur d'Alene River, northern Idaho,

\begin{tabular}{|c|c|c|c|c|c|c|c|c|c|c|}
\hline Sample & Location & $\begin{array}{c}\text { Co } \\
\text { (ppm) }\end{array}$ & $\underset{\text { (ppm) }}{\text { Cs }}$ & $\underset{(\mathbf{p p m})}{\mathbf{C u}}$ & $\begin{array}{l}\text { Fe } \\
\text { (wt } \\
\text { pct) }\end{array}$ & $\begin{array}{c}\mathbf{G a} \\
(\mathbf{p p m})\end{array}$ & $\begin{array}{c}\text { K } \\
\text { (wt } \\
\text { pct) }\end{array}$ & $\begin{array}{c}\text { La } \\
\text { (ppm) }\end{array}$ & $\begin{array}{l}\text { Mg } \\
\text { (wt } \\
\text { pct) }\end{array}$ & $\underset{(\mathbf{p p m})}{\mathrm{Mn}}$ \\
\hline \multicolumn{11}{|c|}{ Coeur d'Alene River streambank sediment deposited after February 21, 1995 flow peak } \\
\hline 43 & North bank above the Idaho Highway 2 bridge --.-- & --6 & 6 & 37 & 4.41 & 11 & 1.94 & 23 & 0.47 & 2,765 \\
\hline 44 & North bank above the Idaho Highway 2 bridge ------.-- & -10 & 7 & 57 & 4.24 & 13 & 1.99 & 28 & 0.55 & 2,337 \\
\hline 45 & North bank at Cataldo Mission boat launch ------------------- & -- 13 & 7 & 158 & 4.52 & 13 & 1.89 & 13 & 0.38 & 2,333 \\
\hline 46 & North bank above Fourth of July Creek - & -9 & 6 & 122 & 9.53 & 9 & 1.47 & 20 & 0.62 & 8,167 \\
\hline 47 & South bank below the Rose Lake bridge & ---9 & 5 & 132 & 9.47 & 9 & 1.36 & 14 & 0.59 & 8,353 \\
\hline 48 & North bank above the Idaho Highway 3 bridge -- & ---9 & 5 & 114 & 10.05 & 7 & 1.16 & 16 & 0.57 & 9,261 \\
\hline
\end{tabular}

Coeur d'Alene River streambank sediment deposited after February 9, 1996 flow peak

\begin{tabular}{|c|c|c|c|c|c|c|c|c|c|}
\hline 49 & South bank below the Smelterville bridge ---_- & 8 & 119 & 7.20 & 12 & 2.37 & 15 & 0.52 & 5,280 \\
\hline 50 & South bank above Pine Creek - & 6 & 137 & 5.03 & 12 & 1.98 & 13 & 0.51 & 3,595 \\
\hline 51 & South bank at Kingston - & 7 & 115 & 4.21 & 15 & 2.39 & 17 & 0.65 & 2,097 \\
\hline 52 & 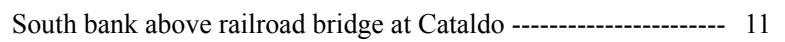 & 8 & 71 & 4.18 & 12 & 2.09 & 24 & 0.59 & 2,336 \\
\hline 53 & North bank above the Idaho Highway 2 bridge --- 10 & 6 & 67 & 6.28 & 12 & 2.64 & 13 & 0.74 & 4,220 \\
\hline 54 & 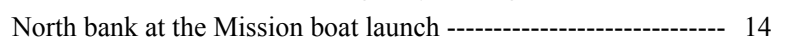 & 10 & 68 & 4.56 & 16 & 2.53 & 29 & 0.80 & 2,379 \\
\hline 55 & South bank below the Rose Lake bridge - - & 6 & 121 & 10.81 & 9 & 1.74 & 14 & 0.66 & 10,070 \\
\hline 56 & North bank $1 \mathrm{mi}$ above the Idaho Highway 3 bridge --------- 11 & 7 & 136 & 10.78 & 11 & 1.98 & 21 & 0.79 & 9,812 \\
\hline 57 & 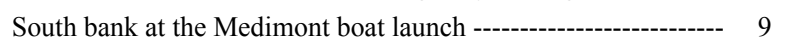 & 5 & 96 & 10.52 & 8 & 1.53 & 13 & 0.65 & 9,241 \\
\hline 58 & North bank at the Thompson Lake inlet boat launch ------------ 11 & 6 & 88 & 9.36 & 9 & 1.64 & 14 & 0.62 & 7,462 \\
\hline 59 & 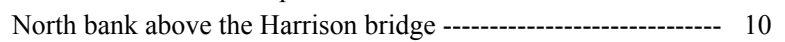 & 5 & 95 & 10.34 & 8 & 1.43 & 11 & 0.57 & 9,221 \\
\hline
\end{tabular}

Coeur d'Alene River floodplain marsh sediment deposited after February 9, 1996 flow peak

\begin{tabular}{|c|c|c|c|c|c|c|c|c|c|c|}
\hline 61 & Cataldo Mission parking lot ------ & 12 & 10 & 59 & 3.89 & 15 & 2.54 & 30 & 0.77 & 1,681 \\
\hline 62 & Lane Marsh, south edge - & 12 & 16 & 56 & 4.49 & 19 & 3.99 & 28 & 0.85 & 1,828 \\
\hline 63 & 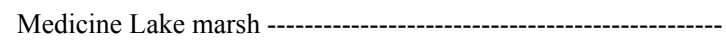 & 11 & 7 & 110 & 9.31 & 10 & 1.72 & 16 & 0.61 & 7,429 \\
\hline 64 & Cave Lake, southeast shore ---------- & 13 & 8 & 39 & 3.49 & 14 & 2.08 & 33 & 0.72 & 969 \\
\hline 65 & Bare Marsh, west edge --- & 13 & 9 & 105 & 4.80 & 14 & 2.32 & 21 & 0.68 & 3,563 \\
\hline 66 & Thompson Lake, north shore - & 11 & 12 & 89 & 5.81 & 17 & 2.84 & 20 & 0.71 & 3,277 \\
\hline
\end{tabular}


Table 2. Analytical data for samples of overbank sediment from the South Fork and main stem of the Coeur d'Alene River, northern Idaho, deposited during high-water events in 1995 and 1996.-Continued

\begin{tabular}{|c|c|c|c|c|c|c|c|c|c|c|c|}
\hline Sample & Location & $\begin{array}{c}\text { Mo } \\
\text { (ppm) }\end{array}$ & $\underset{(\mathbf{p p m})}{\mathbf{N i}}$ & $\underset{(p p m)}{P}$ & $\begin{array}{c}\mathbf{P b} \\
(\mathbf{p p m})\end{array}$ & $\begin{array}{c}\mathbf{R b} \\
(\mathbf{p p m})\end{array}$ & $\underset{(p p m)}{\text { Sb }}$ & $\underset{(\mathbf{p p m})}{\mathrm{Sn}}$ & $\begin{array}{c}\text { Sr } \\
(\mathbf{p p m})\end{array}$ & $\begin{array}{c}\text { Th } \\
\text { (ppm) }\end{array}$ & $\underset{(p p m)}{\mathrm{Ti}}$ \\
\hline \multicolumn{12}{|c|}{ Coeur d'Alene River streambank sediment deposited after February 21, 1995 flow peak } \\
\hline 43 & North bank above the Idaho Highway 2 bridge --------- & -11 & 10 & 264 & 1,662 & 96 & 29 & 3 & 43 & 7 & 810 \\
\hline 44 & North bank above the Idaho Highway 2 bridge ---------------- & -14 & 16 & 506 & 1,625 & 86 & 20 & 3 & 53 & 9 & 1,414 \\
\hline 45 & North bank at Cataldo Mission boat launch --- & -86 & 33 & 370 & 2,247 & 74 & 78 & 3 & 27 & 5 & 1,086 \\
\hline 46 & North bank above Fourth of July Creek - & 8 & 13 & 235 & 4,564 & 75 & 48 & 2 & 36 & 7 & 951 \\
\hline 47 & South bank below the Rose Lake bridge - & --4 & 12 & 254 & 5,010 & 70 & 51 & 2 & 32 & 6 & 820 \\
\hline 48 & North bank above the Idaho Highway 3 bridge -------------- & -6 & 11 & 181 & 4,633 & 59 & 45 & 2 & 26 & 5 & 680 \\
\hline
\end{tabular}

Coeur d'Alene River streambank sediment deposited after February 9, 1996 flow peak

\begin{tabular}{|c|c|c|c|c|c|c|c|c|c|c|c|}
\hline 49 & South bank below the Smelterville bridge -- & 3 & 15 & 417 & 3,835 & 106 & 58 & 1 & 71 & 8 & 1,212 \\
\hline 50 & South bank above Pine Creek --- & 3 & 17 & 503 & 4,950 & 76 & 62 & 1 & 69 & 8 & 1,508 \\
\hline 51 & South bank at Kingston -- & 2 & 22 & 698 & 2,610 & 84 & 47 & 1 & 83 & 10 & 2,302 \\
\hline 52 & South bank above railroad bridge at Cataldo --------------- & 2 & 15 & 497 & 2,410 & 97 & 28 & $<1$ & 59 & 10 & 1,832 \\
\hline 53 & North bank above the Idaho Highway 2 bridge -------------- & 3 & 17 & 381 & 2,050 & 90 & 35 & 1 & 56 & 9 & 1,825 \\
\hline 54 & North bank at the Mission boat launch --- & 2 & 22 & 696 & 1,960 & 111 & 22 & $<1$ & 71 & 14 & 2,409 \\
\hline 55 & South bank below the Rose Lake bridge ------------- & 2 & 11 & 223 & 4,315 & 77 & 38 & 2 & 29 & 6 & 887 \\
\hline 56 & North bank $1 \mathrm{mi}$ above the Idaho Highway 3 bridge ---------- & 3 & 18 & 444 & 6,430 & 90 & 51 & 2 & 46 & 10 & 1,333 \\
\hline 57 & South bank at the Medimont boat launch ------------------ & 2 & 12 & 272 & 3,315 & 65 & 37 & 2 & 32 & 6 & 1,501 \\
\hline 58 & North bank at the Thompson Lake inlet boat launch ----------- & 3 & 15 & 405 & 4,680 & 73 & 36 & 2 & 41 & 7 & 1,339 \\
\hline 59 & North bank above the Harrison bridge -- & 2 & 12 & 252 & 3,970 & 65 & 40 & $<1$ & 29 & 6 & 845 \\
\hline
\end{tabular}

Coeur d'Alene River floodplain marsh sediment deposited after February 9, 1996 flow peak

\begin{tabular}{|c|c|c|c|c|c|c|c|c|c|c|c|}
\hline 60 & Field near the town of Cataldo -- & 4 & 16 & 466 & 3,295 & 99 & 32 & 4 & 59 & 8 & 1,696 \\
\hline 61 & Cataldo Mission parking lot --------- & 2 & 20 & 654 & 1,540 & 122 & 18 & 1 & 67 & 12 & 1,981 \\
\hline 62 & Lane Marsh, south edge -------------- & 2 & 28 & 727 & 1,614 & 184 & 20 & 31 & 63 & 16 & 2,185 \\
\hline 63 & 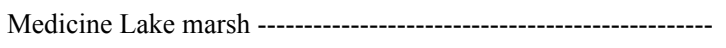 & 1 & 16 & 446 & 4,309 & 74 & 37 & 4 & 44 & 8 & 1,415 \\
\hline 64 & Cave Lake, southeast shore ---------- & 1 & 17 & 694 & 574 & 93 & 6 & 8 & 151 & 12 & 3,341 \\
\hline 65 & Bare Marsh, west edge --- & 6 & 134 & 880 & 1,693 & 123 & 20 & 79 & 83 & 10 & 1,924 \\
\hline 66 & Thompson Lake, north shore - & 1 & 21 & 596 & 2,548 & 143 & 31 & 7 & 53 & 11 & 2,190 \\
\hline
\end{tabular}


Table 2. Analytical data for samples of overbank sediment from the South Fork and main stem of the Coeur d'Alene River, northern Idaho, deposited during high-water events in 1995 and 1996. - Continued

\begin{tabular}{|c|c|c|c|c|c|c|c|c|}
\hline Sample & Location & $\begin{array}{c}\mathrm{TI} \\
\text { (ppm) }\end{array}$ & $\underset{\text { (ppm) }}{\mathbf{U}}$ & $\underset{(\mathbf{p p m})}{\mathbf{V}}$ & $\underset{(\mathbf{p p m})}{\mathbf{W}}$ & $\underset{(\mathbf{p p m})}{Y}$ & $\underset{(\mathbf{p p m})}{\mathrm{Zn}}$ & $\underset{(p p m)}{Z r}$ \\
\hline \multicolumn{9}{|c|}{ Coeur d'Alene River streambank sediment deposited after February 21, 1995 flow peak } \\
\hline 43 & North bank above the Idaho Highway 2 bridge -------------- & ---0.56 & 10.6 & 32 & 1 & 7 & 982 & 38 \\
\hline 44 & North bank above the Idaho Highway 2 bridge ---------- & -0.59 & 2.8 & 41 & 2 & 11 & 1,205 & 56 \\
\hline 45 & North bank at Cataldo Mission boat launch ------------------- & -0.64 & 3.2 & 30 & 3 & 7 & 1,480 & 42 \\
\hline 46 & North bank above Fourth of July Creek - & ---0.45 & 2.0 & 29 & 1 & 8 & 6,850 & 38 \\
\hline 47 & South bank below the Rose Lake bridge - & 0.47 & 1.6 & 28 & 1 & 8 & 7,835 & 34 \\
\hline 48 & North bank above the Idaho Highway 3 bridge --- & ---0.45 & 1.3 & 23 & 1 & 7 & 8,250 & 29 \\
\hline
\end{tabular}

Coeur d'Alene River streambank sediment deposited after February 9, 1996 flow peak

\begin{tabular}{|c|c|c|c|c|c|c|c|c|}
\hline 49 & South bank below the Smelterville bridge -- & 0.73 & 2.5 & 41 & 2 & 8 & 2,410 & 40 \\
\hline 50 & South bank above Pine Creek -- & 0.66 & 3.2 & 41 & 2 & 8 & 3,025 & 50 \\
\hline 51 & South bank at Kingston -------------------- & 0.79 & 4.8 & 60 & 3 & 12 & 1,330 & 72 \\
\hline 52 & South bank above railroad bridge at Cataldo --- & 0.52 & 3.7 & 44 & 2 & 14 & 1,210 & 59 \\
\hline 53 & North bank above the Idaho Highway 2 bridge --- & 0.73 & 3.1 & 44 & 2 & 8 & 1,205 & 64 \\
\hline 54 & North bank at the Mission boat launch --- & 0.69 & 5.3 & 59 & 3 & 20 & 1,380 & 80 \\
\hline 55 & South bank below the Rose Lake bridge - & 0.49 & 2.1 & 27 & 1 & 8 & 7,870 & 30 \\
\hline 56 & North bank $1 \mathrm{mi}$ above the Idaho Highway 3 bridge ------- & 0.63 & 2.9 & 37 & 2 & 14 & 6,415 & 47 \\
\hline 57 & South bank at the Medimont boat launch -- & 0.42 & 1.7 & 35 & 1 & 8 & 5,840 & 32 \\
\hline 58 & North bank at the Thompson Lake inlet boat launch ---------- & 0.53 & 2.1 & 36 & 1 & 9 & 4,025 & 37 \\
\hline 59 & North bank above the Harrison bridge -- & 0.45 & 1.7 & 25 & 8 & 7 & 5,480 & 29 \\
\hline
\end{tabular}

Coeur d'Alene River floodplain marsh sediment deposited after February 9, 1996 flow peak

\begin{tabular}{|c|c|c|c|c|c|c|c|c|}
\hline 60 & Field near the town of Cataldo --- & 0.57 & 2.3 & 47 & 2 & 10 & 1,955 & 47 \\
\hline 61 & Cataldo Mission parking lot --- & 0.61 & 4.6 & 55 & 3 & 18 & 835 & 65 \\
\hline 62 & Lane Marsh, south edge ------------ & 1.00 & 3.0 & 83 & 6 & 17 & 1,021 & 78 \\
\hline 63 & 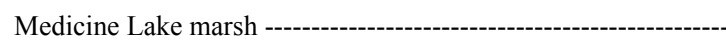 & 0.60 & 3.0 & 40 & 2 & 9 & 4,062 & 52 \\
\hline 64 & Cave Lake, southeast shore -- & 0.70 & 2.0 & 77 & 4 & 18 & 507 & 80 \\
\hline 65 & Bare Marsh, west edge --1-- & 0.70 & 2.0 & 58 & 3 & 11 & 1,649 & 66 \\
\hline 66 & Thompson Lake, north shore -------- & 0.90 & 3.0 & 72 & 4 & 12 & 1,961 & 71 \\
\hline
\end{tabular}


Table 3. Daily metal loads in suspended sediment at selected sampling sites in the Coeur d'Alene-Spokane River system, northern Idaho and eastern Washington.

[See figures 1 and 2 for location w data for each sampling date, extrapolated from

mean daily streamflow measured at nearby U.S. Geological Survey gaging stations (U.S. Geological Survey, 1997, 1998)

\begin{tabular}{|c|c|c|c|c|c|c|c|c|c|c|c|}
\hline \multirow{2}{*}{ Sample } & \multirow{2}{*}{ Location } & \multirow{2}{*}{$\begin{array}{l}\text { River miles } \\
\text { below } \\
\text { Mullan, Idaho }\end{array}$} & \multirow{2}{*}{$\begin{array}{l}\text { Suspended- } \\
\text { sediment } \\
\text { concentration } \\
\text { (mg/L) }\end{array}$} & \multirow{2}{*}{$\begin{array}{c}\text { Mean } \\
\text { daily } \\
\text { streamflow } \\
\left(\mathrm{ft}^{3} \mathbf{s}\right)\end{array}$} & \multicolumn{3}{|c|}{$\begin{array}{l}\text { Metal content of } \\
\text { suspended sediment }\end{array}$} & \multirow{2}{*}{$\begin{array}{l}\text { Suspended- } \\
\text { sediment } \\
\text { daily load } \\
\text { (tons/day) }\end{array}$} & \multirow{2}{*}{$\begin{array}{l}\text { Daily } \\
\text { Pb load } \\
\text { (lb/day) }\end{array}$} & \multirow{2}{*}{$\begin{array}{c}\text { Daily } \\
\text { Zn load } \\
\text { (lb/day) }\end{array}$} & \multirow{2}{*}{$\begin{array}{l}\text { Daily } \\
\text { Fe load } \\
\text { (Ib/day) }\end{array}$} \\
\hline & & & & & $\begin{array}{c}\mathrm{Pb} \\
(\mathrm{ppm})\end{array}$ & $\underset{(\mathrm{ppm})}{\mathrm{Zn}}$ & $\begin{array}{c}\mathrm{Fe} \\
\text { (wt pct) }\end{array}$ & & & & \\
\hline \multicolumn{12}{|c|}{ Coeur d'Alene River, February 9-10, 1996} \\
\hline 1 & South Fork at Twomile Creek & 12.5 & 616 & 6,000 & 4,035 & 2,820 & 4.69 & 9,947 & 80,274 & 56,102 & 933,066 \\
\hline 2 & South Fork at the Smelterville bridge -- & 22.4 & 1388 & 8,000 & 6,360 & 2,515 & 6.50 & 29,861 & 379,827 & 150,199 & $3,879,131$ \\
\hline 3 & South Fork above Pine Creek & 25.3 & 104 & 9,900 & 4,235 & 3,280 & 5.31 & 2,772 & 23,481 & 18,186 & 294,454 \\
\hline 4 & Coeur d'Alene River at Kingston - & 27.8 & 534 & 56,000 & 1,765 & 1,505 & 4.82 & 80,367 & 283,694 & 241,903 & $7,747,911$ \\
\hline 5 & Coeur d'Alene River at the Idaho Highway 2 bridge -------- & 32.0 & 490 & 56,000 & 1,075 & 838 & 4.24 & 73,773 & 158,613 & 123,644 & $6,258,082$ \\
\hline 6 & Coeur d'Alene River above Dudley - & 37.3 & 52 & 56,000 & 2,480 & 1,560 & 5.91 & 7,841 & 38,890 & 24,463 & 927,417 \\
\hline 7 & Coeur d'Alene River below Rose Lake -- & 43.4 & 426 & 56,000 & 2,060 & 1,280 & 5.83 & 64,151 & 264,301 & 164,226 & $7,477,978$ \\
\hline 8 & Coeur d'Alene River at Anderson Lake inlet--------------- & 61.4 & 138 & 56,000 & 5,925 & 4,065 & 10.10 & 20,849 & 247,060 & 169,502 & $4,213,409$ \\
\hline \multicolumn{12}{|c|}{ Tributaries to Coeur d'Alene River, February 9-10, 1996} \\
\hline 9 & Canyon Creek at mouth --1 & 7.0 & 14 & 1,000 & 17,310 & 9,580 & 6.40 & 38 & 1,322 & 732 & 4,884 \\
\hline \multicolumn{12}{|c|}{ Coeur d'Alene River, January 2, 1997} \\
\hline 11 & South Fork at Enaville - - & & 104 & 3,850 & 3,832 & 4,575 & 4.06 & 1,075 & 8,241 & 9,839 & 87,388 \\
\hline \multicolumn{12}{|c|}{ Tributaries to Coeur d'Alene River, January 2, 1997} \\
\hline 12 & Canyon Creek at mouth - - & 7.0 & 7 & 225 & 13,929 & 19,567 & 5.61 & 4 & 115 & 161 & 462 \\
\hline 13 & 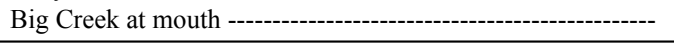 & 15.8 & 25 & 200 & 294 & 340 & 2.84 & 13 & 8 & 9 & 759 \\
\hline \multicolumn{12}{|c|}{ Spokane Rivers, May 2, 1997} \\
\hline 17 & Spokane River at the Stateline bridge --- & 98.3 & 3 & 34,800 & 1,404 & 3,068 & 4.70 & 270 & 758 & 1,656 & 25,385 \\
\hline 18 & Spokane River at the Centennial Trail bridge --- & 110.2 & 4 & 34,800 & 898 & 2,430 & 3.46 & 381 & 684 & 1,850 & 26,329 \\
\hline 19 & Spokane River at the Gonzaga University bridge --------- & 119.0 & 5 & 34,800 & 1,293 & 3,169 & 4.65 & 424 & 1,097 & 2,690 & 39,434 \\
\hline 20 & Spokane River at the 7-Mile bridge ----- & 132.4 & 16 & 34,800 & 532 & 1,690 & 5.33 & 1,511 & 1,608 & 5,106 & 161,104 \\
\hline \multicolumn{12}{|c|}{ Coeur d'Alene-Spokane Rivers, May 19-20, 1997} \\
\hline 27 & South Fork at Evolution bridge - & 14.3 & 58 & 1,637 & 2,098 & 2,494 & 3.08 & 257 & 1,078 & 1,282 & 15,845 \\
\hline 28 & South Fork at Enaville - & 26.7 & 83 & 2,650 & 2,618 & 3,805 & 3.98 & 590 & 3,088 & 4,488 & 46,913 \\
\hline 29 & Coeur d'Alene River at the Idaho Highway 2 bridge -------- & 32.0 & 20 & 12,100 & 1,909 & 3,762 & 4.13 & 636 & 2,429 & 4,786 & 52,560 \\
\hline 30 & Coeur d'Alene River at the Idaho Highway 3 bridge ------- & 44.2 & 20 & 12,100 & 1,233 & 2,403 & 4.78 & 636 & 1,607 & 3,131 & 62,256 \\
\hline 31 & Spokane River at the Idaho Highway 95 bridge -- & 83.6 & 2 & 43,200 & 2,318 & 3,708 & 5.59 & 179 & 829 & 1,327 & 19,992 \\
\hline 32 & Spokane River above the Post Falls dam --- & 92.3 & 3 & 43,200 & 1,275 & 3,046 & 4.10 & 372 & 949 & 2,266 & 30,513 \\
\hline 33 & Spokane River at the Stateline footbridge - & 98.0 & 4 & 43,200 & 1,611 & 3,440 & 4.53 & 512 & 1,648 & 3,520 & 46,404 \\
\hline 34 & Spokane River at Sullivan Rd - & 106.7 & 9 & 43,200 & 1,324 & 3,489 & 4.86 & 1,081 & 2,864 & 7,545 & 105,008 \\
\hline 35 & Spokane River at the Gonzaga University bridge ---------- & 119.0 & 5 & 43,200 & 2,015 & 4,234 & 6.42 & 536 & 2,159 & 4,536 & 68,748 \\
\hline \multicolumn{12}{|c|}{ Tributaries to the Coeur d'Alene River, May 20, 1997} \\
\hline 37 & Canyon Creek above mouth --- & 7.0 & 7 & 290 & 9,793 & 5,818 & 5.57 & 5 & 100 & 59 & 566 \\
\hline 39 & Big Creek at mouth -- & 15.8 & 4 & 253 & 224 & 492 & 2.88 & 3 & 1 & 3 & 175 \\
\hline
\end{tabular}

